\title{
Toward Assessing the Effects of Bank Stabilization Activities on Wildlife Communities of the Upper Yellowstone River, U.S.A.
}

Open File Report 01-58

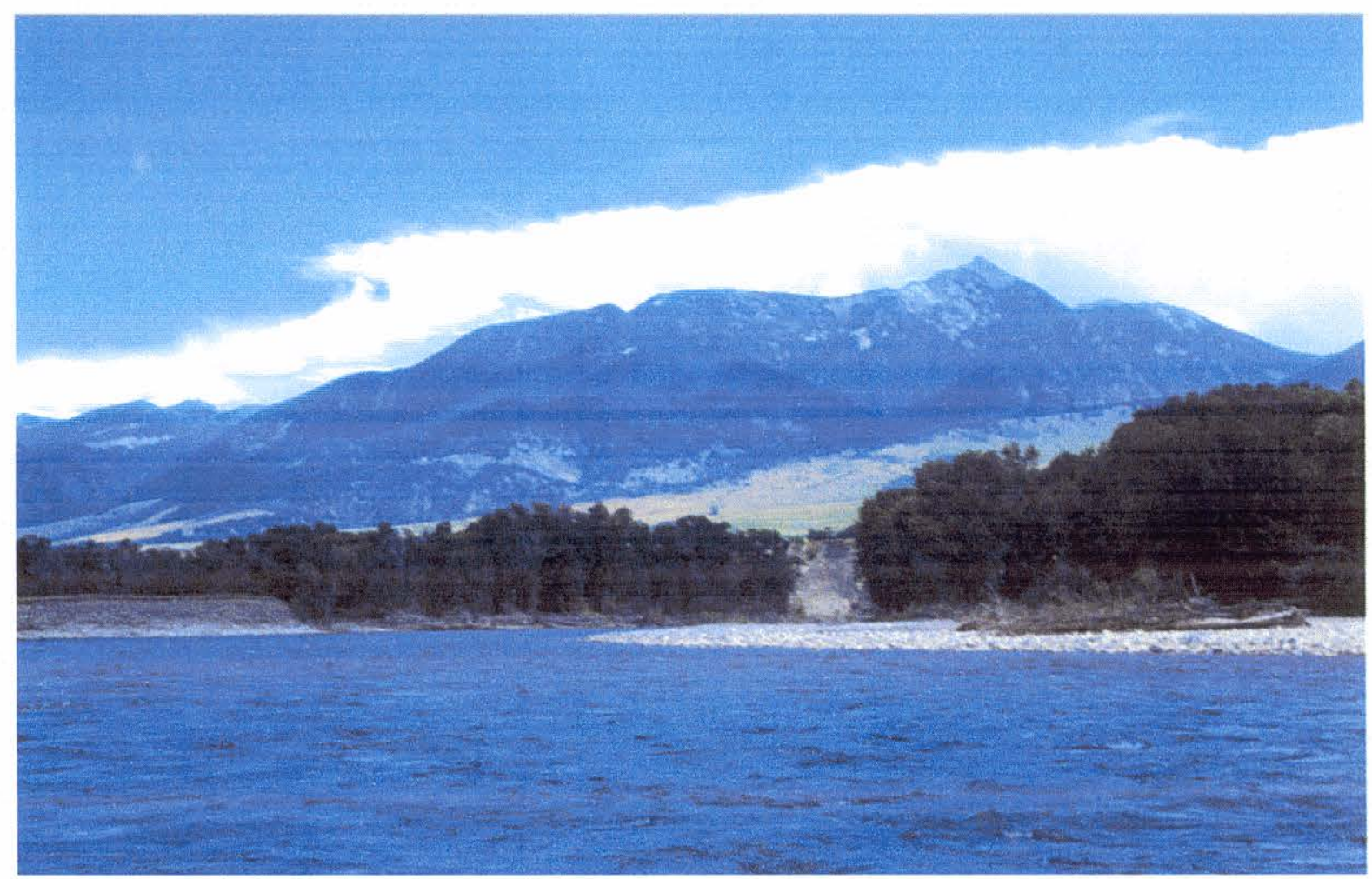

U.S. Department of the Interior

U.S. Geological Survey

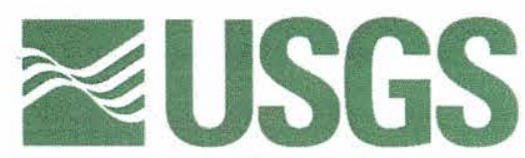

science for a changing world 

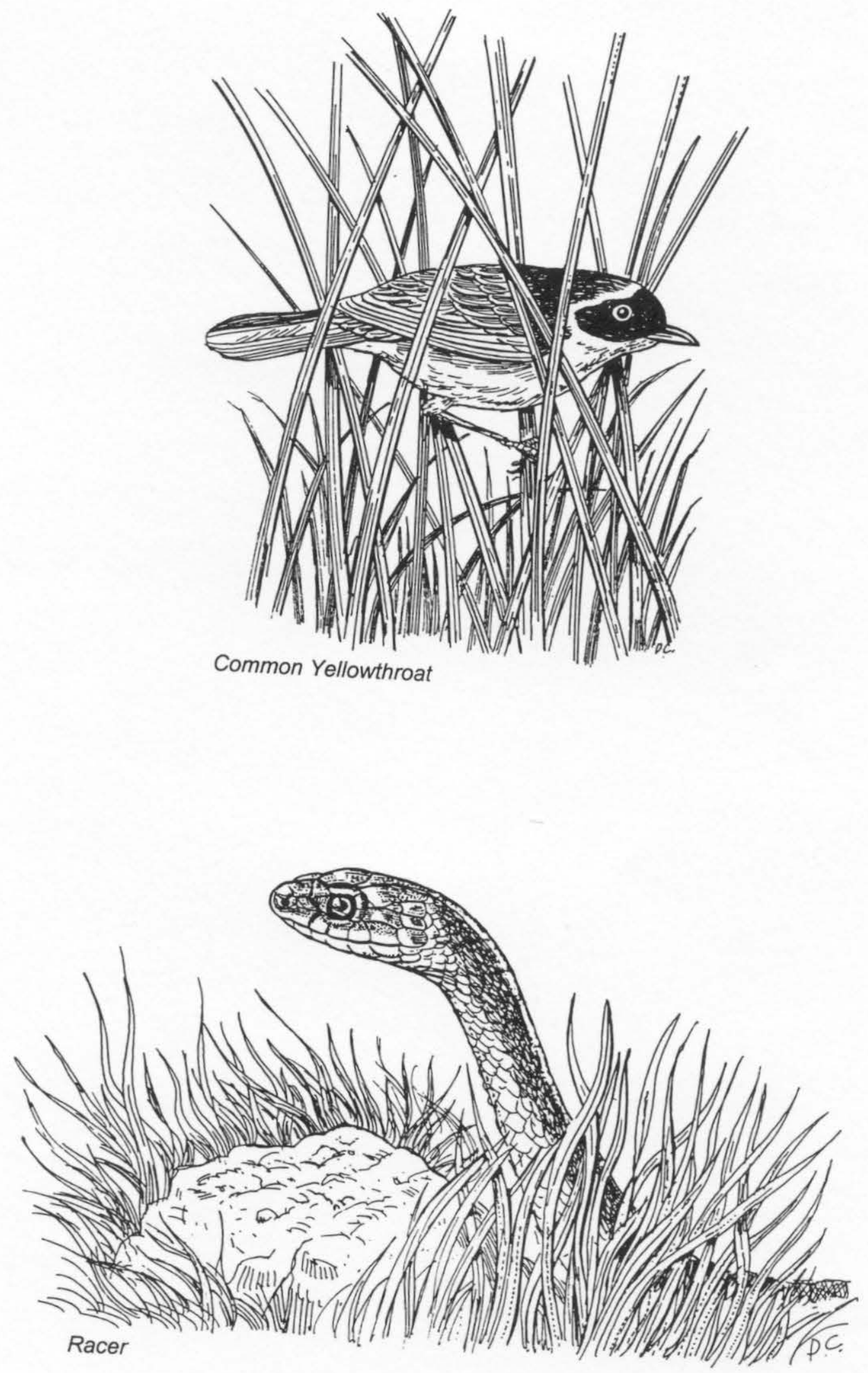


\title{
U.S. DEPARTMENT OF THE INTERIOR
}

U.S. GEOLOGICAL SURVEY

\section{Toward Assessing the Effects of Bank Stabilization Activities on Wildlife Communities of the Upper Yellowstone River, U.S.A.}

\author{
By \\ ${ }^{1}$ Susan K. Skagen and Erin Muths, U.S. Geological Survey \\ ${ }^{2}$ Rod D. Adams, Colorado State University
}

Open-File Report 01-58

Prepared in cooperation with U.S. Fish and Wildlife Service, Region 6

This report is preliminary and has not been reviewed for conformity with U.S. Geological Survey editorial standards (or with the North American Stratigraphic Code). Any use of trade, product, or firm names is for descriptive purposes only and does not imply endorsement by the U.S. Government.

${ }^{1} 4512$ McMurry Avenue, Fort Collins, CO 80525

${ }^{2}$ Department of Philosophy, Fort Collins, CO 80523 
Cover photo by: Michael L. Scott

\section{Suggested citation:}

Skagen, S. K., E. Muths, and R. D. Adams. 2001. Toward assessing the effects of bank stabilization activities on wildlife communities of the Upper Yellowstone River, U.S.A. U.S. Geological Survey, Midcontinent Ecological Science Center, Fort Collins, CO. 76 pp. 


\section{Contents}

Abstract

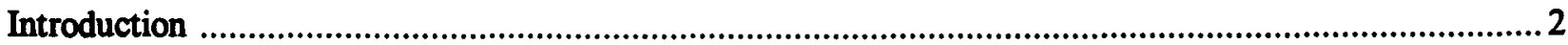

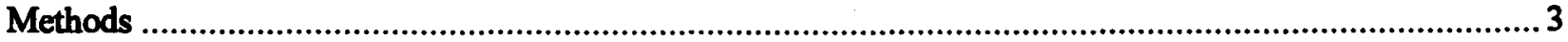

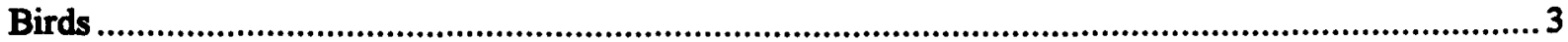

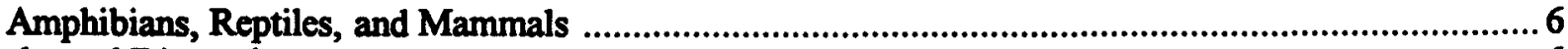

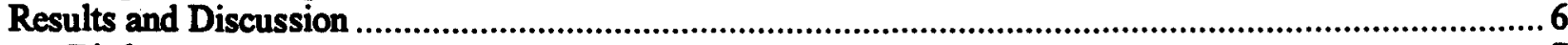

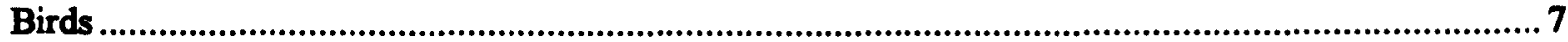

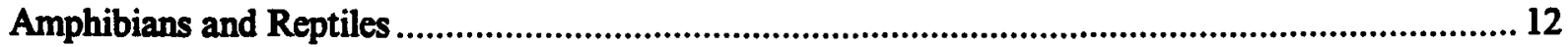

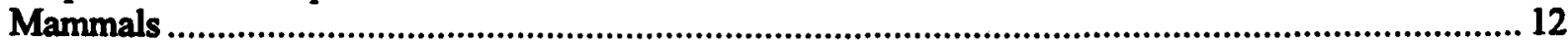

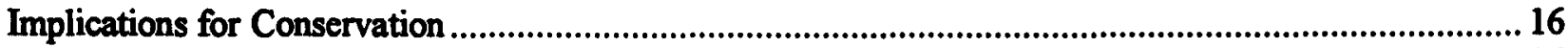

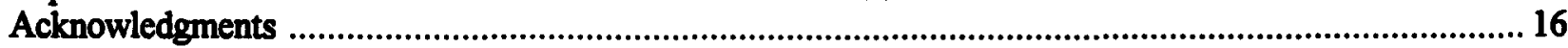

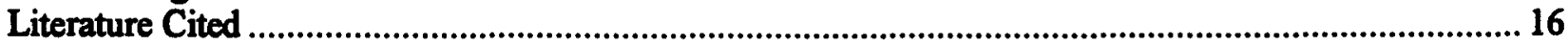

Appendix 1. Brief Species Accounts, Including Occurrence, Abundance, and Life History

Information for 69 Bird Species, 4 Amphibians, 5 Reptiles, and 9 Mammals of the Upper

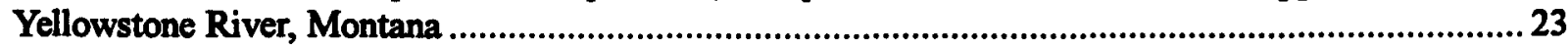

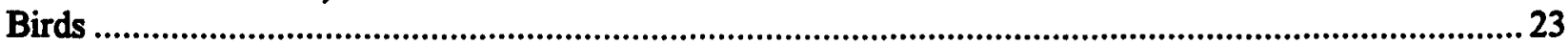

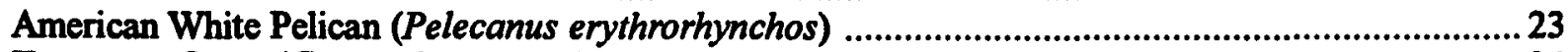

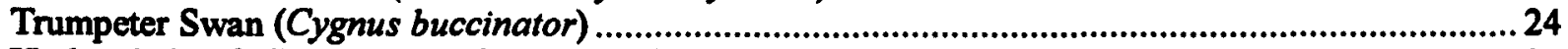

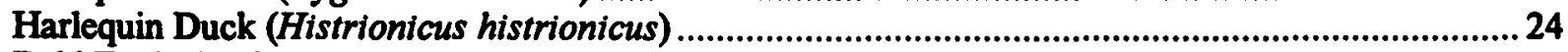

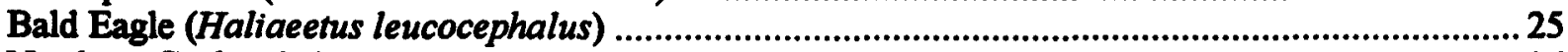

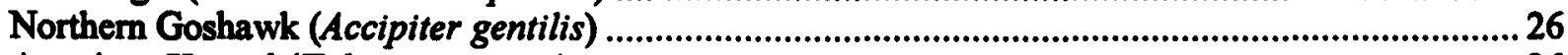

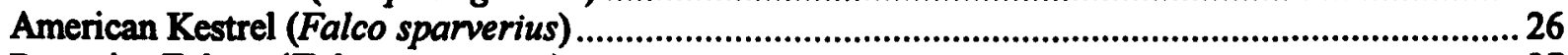

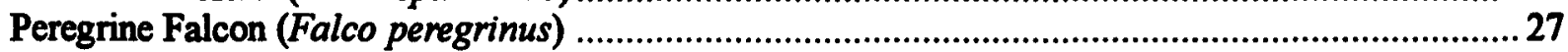

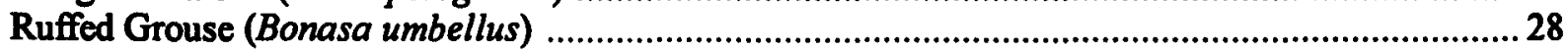

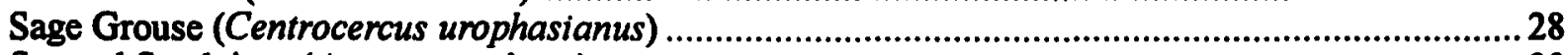

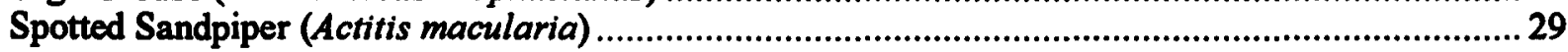

Mourning Dove (Zenaida macroura) .....................................................................................29

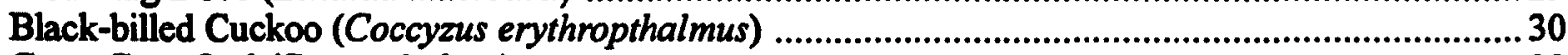

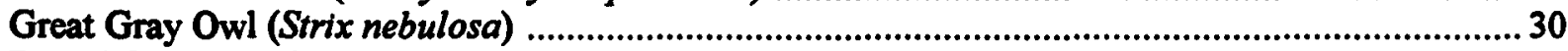

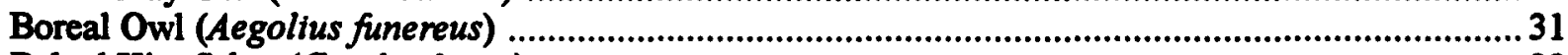

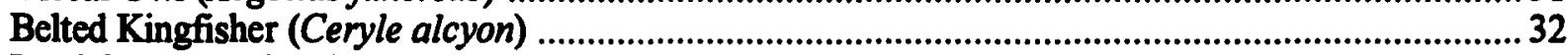

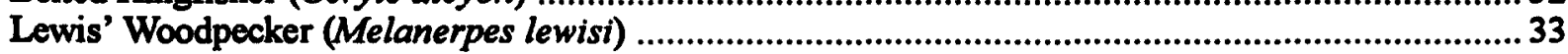

Red-naped Sapsucker (Sphyrapicus nuchalis) ....................................................................... 33

Downy Woodpecker (Picoides pubescens) ............................................................................. 34

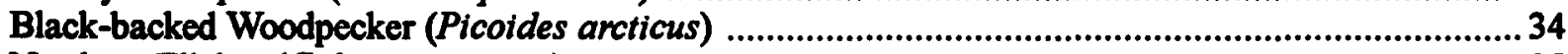

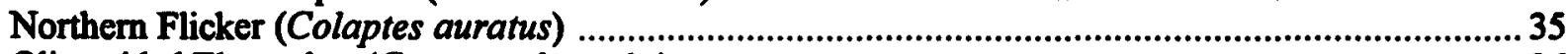

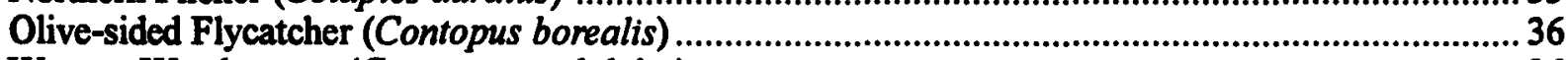

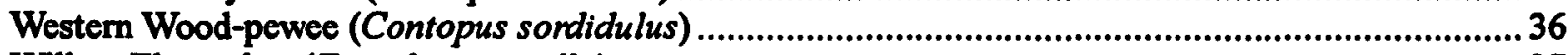

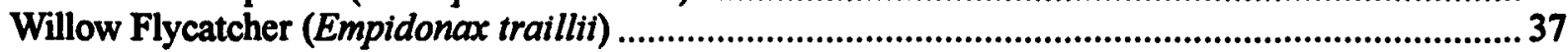

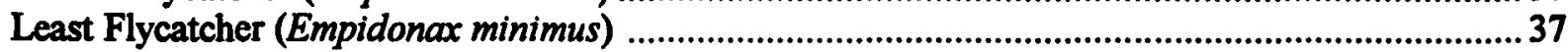

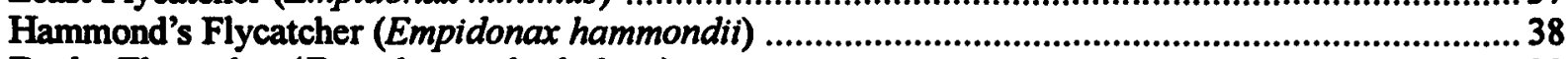

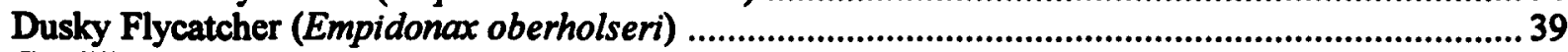

Cordilleran Flycatcher (Empidonax occidentalis) ................................................................... 39

Eastem Kingbird (Tyrannus tyrannus) ........................................................................ 40

Plumbeous Vireo (Vireo plumbeus); formerly a subspecies of Solitary Vireo (Vireo solitarius)........... 40

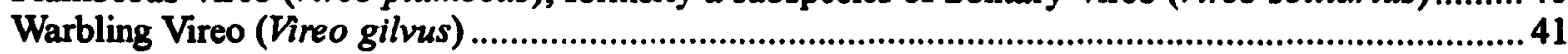

Red-eyed Vireo (Vireo olivaceus) ...................................................................................... 42

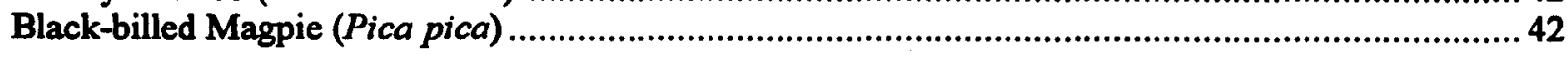




\section{Contents (Continued)}

American Crow (Corvus brachyrhynchos) 43

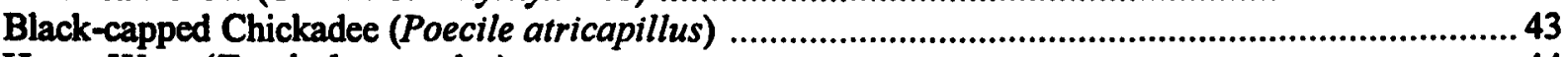

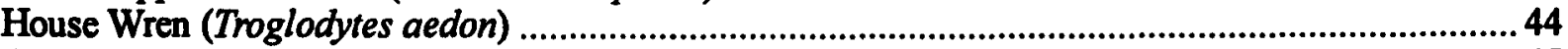

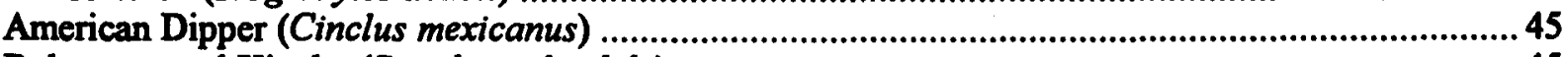

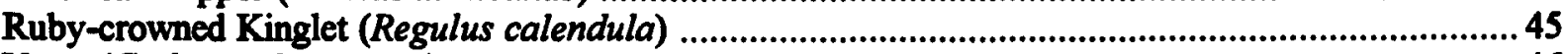

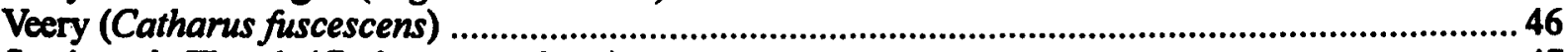

Swainson's Thrush (Catharus ustulatus) .............................................................................47

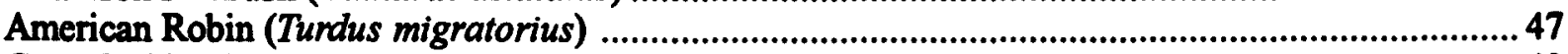

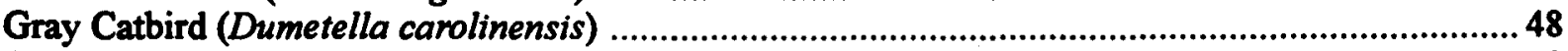

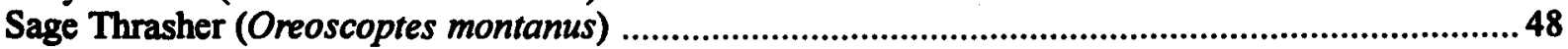

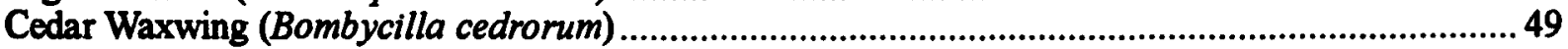

Orange-crowned Warbler (Vermivora celata) ..........................................................................50

Yellow Warbler (Dendroica petechia) ................................................................................... 50

Yellow-rumped Warbler (Dendroica coronata) ...................................................................... 51

American Redstart (Setophaga ruticilla) ............................................................................51

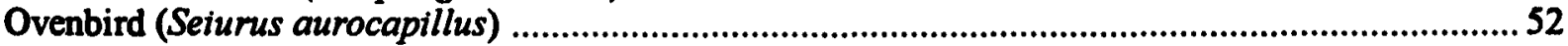

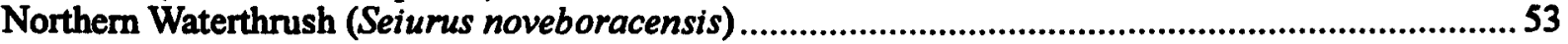

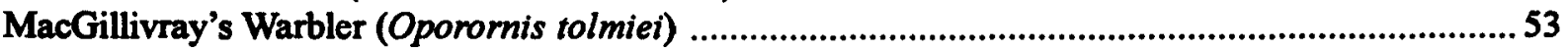

Common Yellowthroat (Geothlypis trichas) .............................................................................5 54

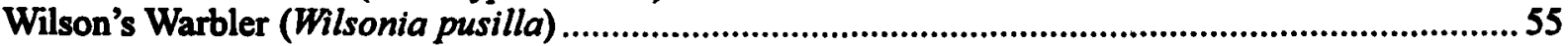

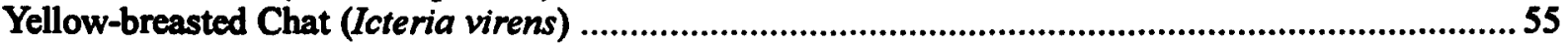

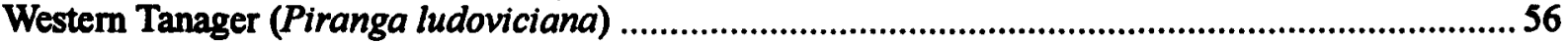

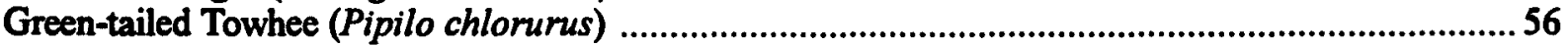

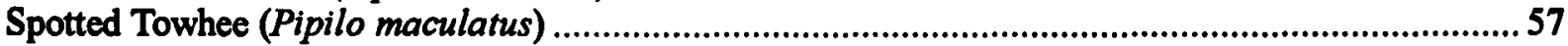

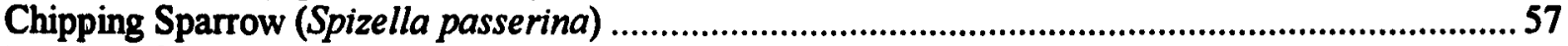

Brewer's Sparrow (Spizella breweri) .........................................................................................5 58

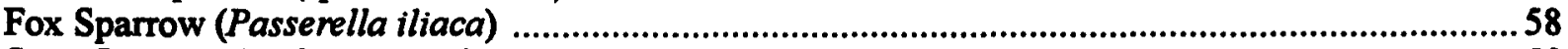

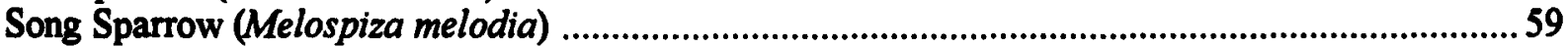

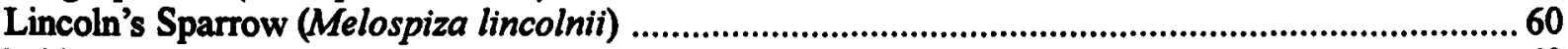

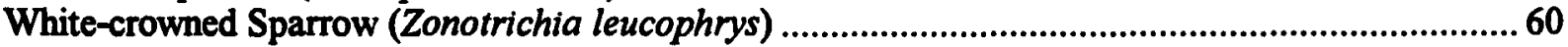

Black-headed Grosbeak (Pheucticus melanocephalus) .......................................................6 61

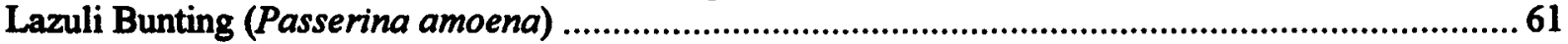

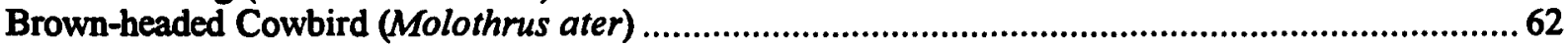

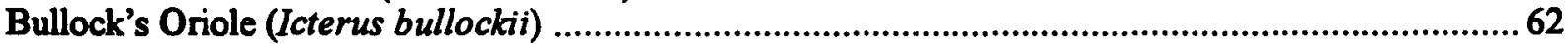

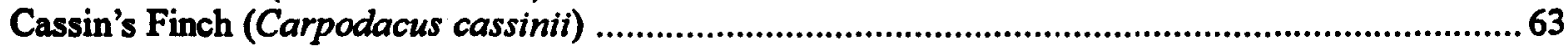

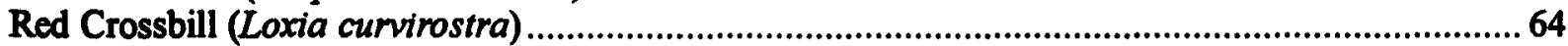

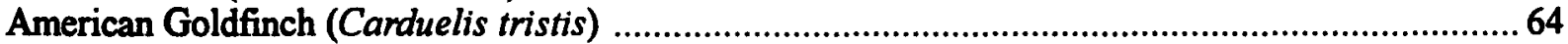

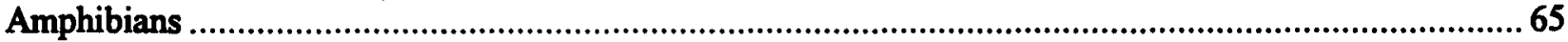

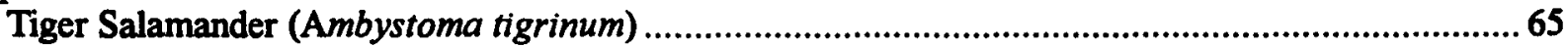

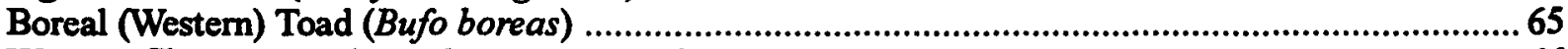

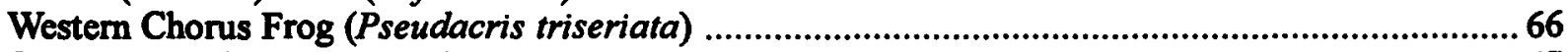

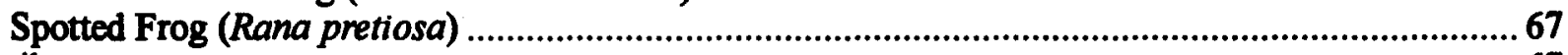

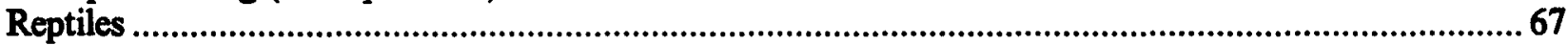

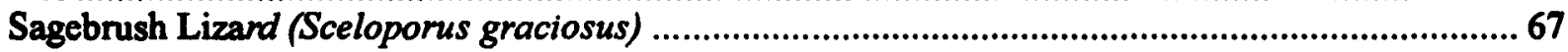

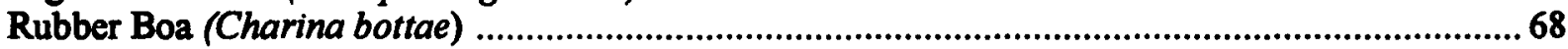

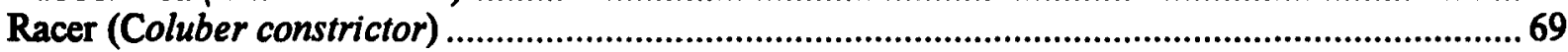

Western Terrestrial Garter Snake (Thamnophis elegans) ....................................................69

Westem Rattlesnake (Crotalus viridis) ........................................................................................ 70 


\section{Contents (Concluded)}

$\underline{\text { Page }}$

Mammals 71

Water Shrew (Sorex palustris) ...................................................... 71

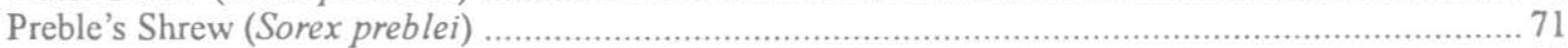

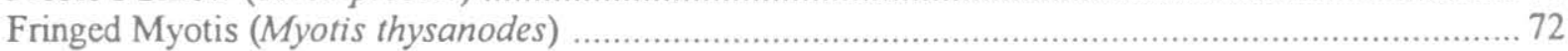

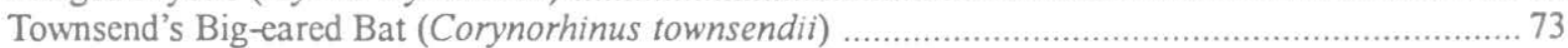

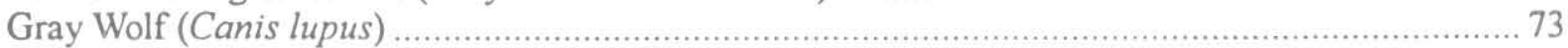

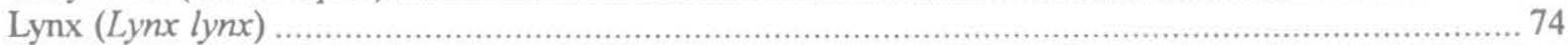

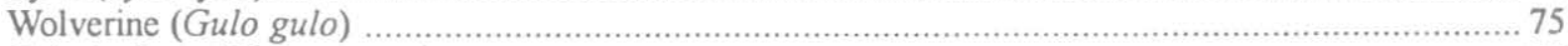

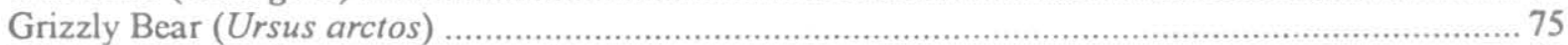

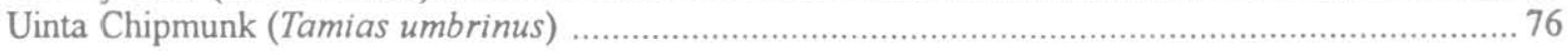

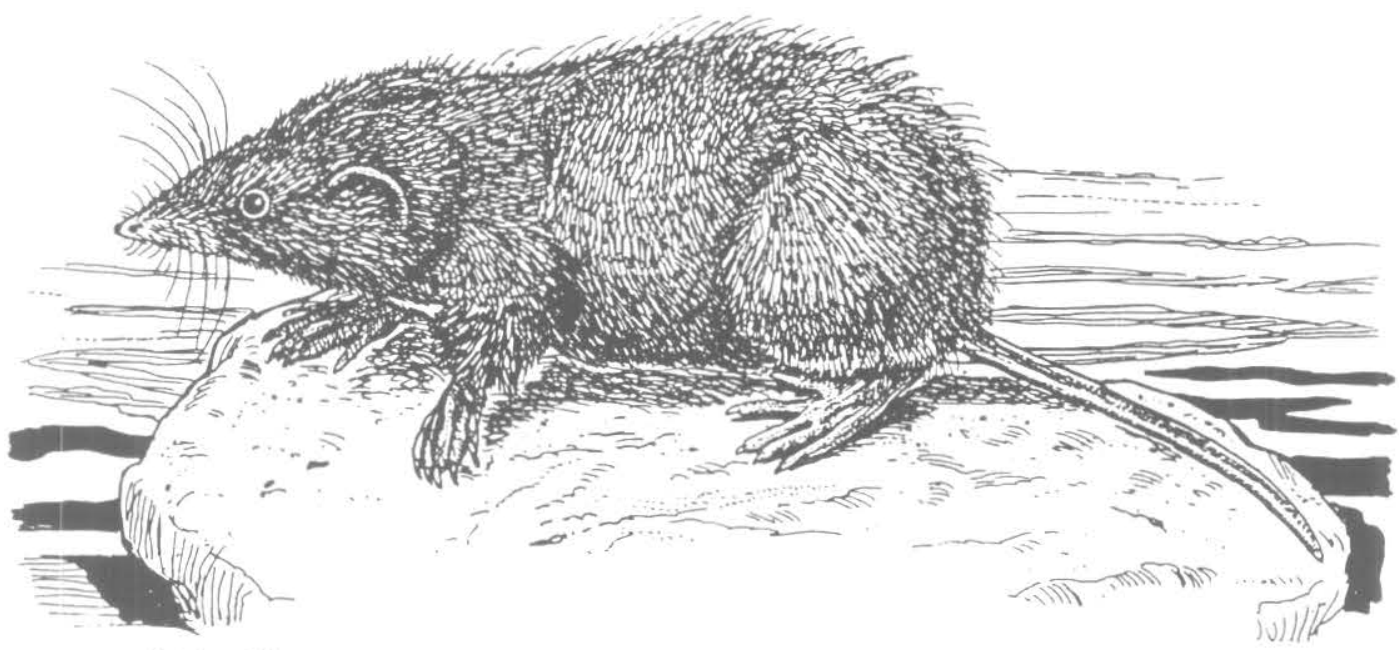

Water Shrew 

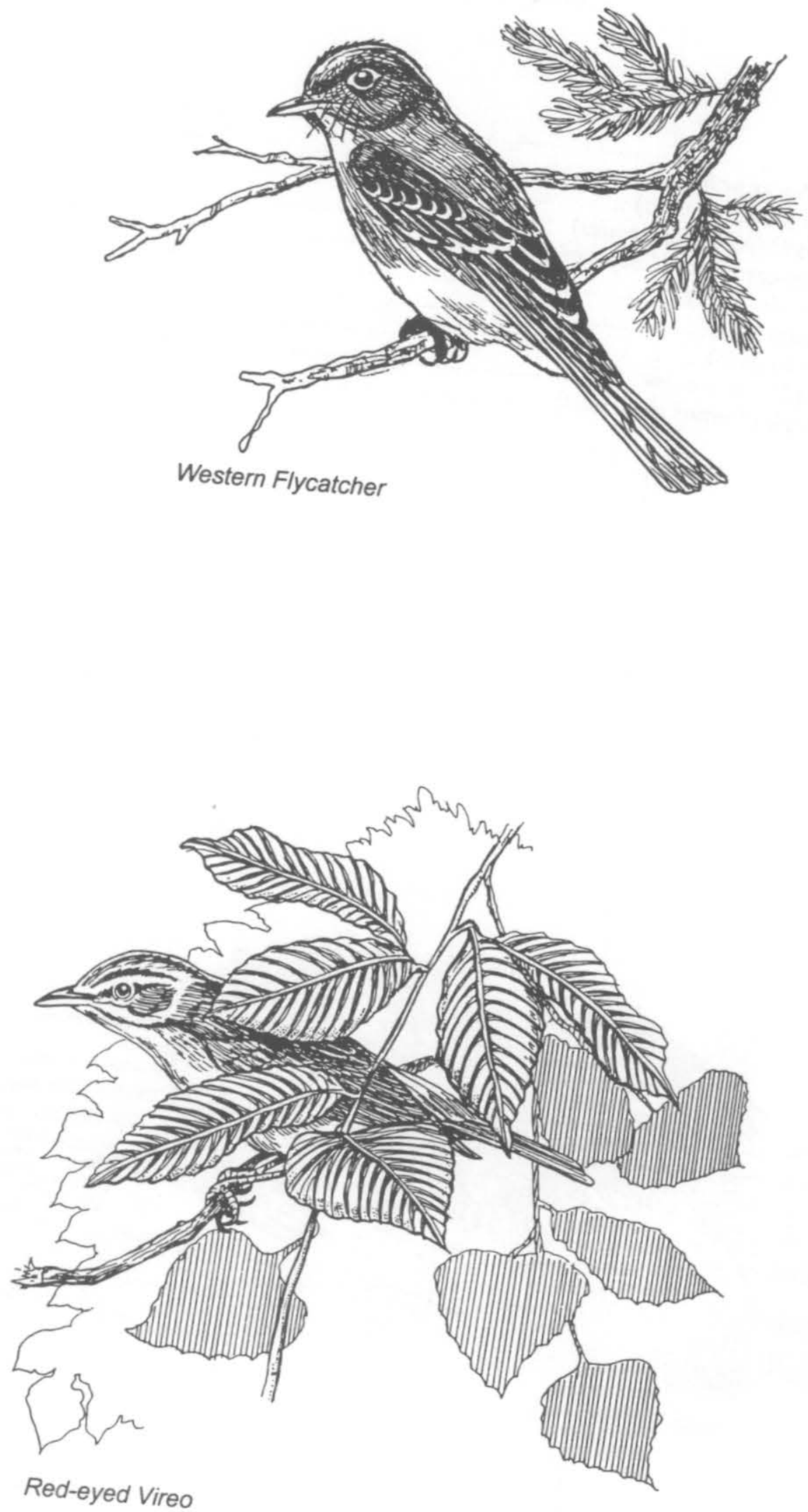


\title{
Toward Assessing the Effects of Bank Stabilization Activities on Wildlife Communities of the Upper Yellowstone River, USA
}

\author{
By \\ Susan K. Skagen, Erin Muths, and Rod D. Adams \\ Biological Resources Division \\ U.S. Geological Survey \\ Midcontinent Ecological Science Center \\ 4512 McMurry Avenue \\ Fort Collins, Colorado 80525
}

\begin{abstract}
The upper Yellowstone River has been subject to multiple bank stabilization projects between Gardiner and Springdale, Montana, over the last 20 years. Additional channel modification activities are likely on the Yellowstone, and there is concern over the short- and long-term cumulative effects of channel modification activities on physical processes and dynamics of the river, associated riparian vegetation, and fish and wildlife resources that depend on the river.

This document represents a first step toward conservation of the riparian vertebrate community on the upper Yellowstone River, with expected changes due to bank stabilization activities. Conservation strategies should be based on the life history attributes of the species of interest and the expected landscape changes for a specific geographic region. In this document, species accounts summarize the distribution, abundance, life histories, and habitat associations of 69 bird species, 4 amphibian species, 5 reptile species, and 9 species of mammals known or assumed to occur in the study area, including 38 species designated as species of interest. A matrix is presented to assist managers in evaluating the degree to which a species may be negatively affected by riverbank stabilization activities.

The degree of vulnerability of birds to bank stabilization activities and changes in stream flow is strongly related to the degree to which the species is tied to riparian habitats. Of birds, the 13 species that are riparian obligates are the most vulnerable to bank stabilization activities. Belted Kingfishers would suffer if fish populations decline. Harlequin Ducks, Spotted Sandpipers, and American Dippers would be negatively influenced by changes in stream and bank morphology, especially the loss of shallow water and braided channels. Willow Flycatchers, Redeyed Vireos, Yellow Warblers, American Redstarts, Northern Waterthrushes, Common Yellowthroats, Wilson's Warblers, Song Sparrows, and Lincoln's Sparrows would be negatively affected if stream flow changes resulted in eventual reductions in the extent of shrub understory. Species that are affected by changes in fish populations and stream morphology would suffer more rapid changes than species affected primarily by changes in riparian vegetation (either understory or trees), which would occur over a much longer period of time.

Four amphibian species, three reptile species, and one mammal species are highly vulnerable to bank stabilization activities. Tiger salamanders, boreal toads, western chorus frogs, spotted frogs, rubber boas, racers, western garter snakes, and water shrews are expected to respond primarily to alterations in stream and bank morphology and the loss of still water for amphibian breeding.
\end{abstract}




\section{Introduction}

The upper Yellowstone River in Montana is both a significant natural resource and a valuable economic resource for the state and the nation. Maintenance of healthy fish and wildlife populations along western rivers depends on natural ecosystem processes, including periodic flooding. The upper Yellowstone River has been subject to multiple bank-stabilization projects between Gardiner and Springdale, Montana, over the last 20 years as landowners made channel modifications to reduce erosion and protect their resources. Currently, this 80mile stretch of river contains approximately 22 miles of riverbank protection (rock rip-rap, jetties, and dikes). Two recent floods in 1996 and 1997 resulted in additional bank stabilization projects. There will likely be more bank stabilization projects in the near future.

Because additional channel modification activities are likely on the Yellowstone, there is concern over the short- and long-term cumulative effects of such activities on physical processes and dynamics of the river. Of additional concern is the effect changing river dynamics might have on the channel and associated riparian vegetation, and the fish and wildlife resources that depend on the river. A multi-disciplinary effort, the upper Yellowstone River Cumulative Effects Investigation, is being launched to evaluate effects of past bank stabilization activities and to predict the effects of future activities. The investigation is endorsed by the Governor's Upper Yellowstone River Task Force.

Of all the habitats in the western U.S., riparian habitats support the highest diversity of breeding birds. In Montana, 55\% of 245 species of breeding birds use riparian forests during all, or part of the year (Montana Partners In Flight 2000), yet broadleaf riparian habitat constitutes only about $0.5 \%$ of the land base (Redmond et al. 1998).

How vertebrate communities might respond to environmental perturbations is difficult to predict. Vertebrate responses to landscape perturbations such as fire, grazing, and forest fragmentation have been documented for many species in several geographic areas (Hutto 1995, Dobkin et al. 1998, Faaborg et al. 1998, Rosenberg et al. 1999). Avian responses to changes in fluvial geomorphology, stream flow, and subsequent effects on riparian vegetation, however, have received little attention (Scott et al., in review).

Responses are influenced by the types of landscape perturbations, life history attributes of the vertebrate species (Hansen and Urban 1992), predator/parasite communities (Tewksbury et al. 1998), and geographic differences. Several studies have concluded that it is inappropriate to make inferences about the effects of landscape perturbations, such as fragmentation across broad geographic regions. Hansen and Urban (1992) suggest that differences in the life history traits of communities can result in unique responses of distinct communities to landscape change. For example, forest bird communities of the Pacific Northwest are less sensitive to patch size and edge effect phenomena than forest bird communities of the eastern deciduous forest. Differences in sensitivity, they surmise, are due to differences in the degree of fragmentation of the respective forests or to fundamental differences between the two avifauna. Similarly, Rosenberg et al. (1999) illustrate large geographical differences in tanager (Piranga spp.) responses to fragmentation and explore the differences in predator communities. They conclude that results of forest fragmentation studies from one area cannot be extrapolated to other regions without considerable caution. Finally, Tewksbury et al. (1998) conclude that landscape-level processes determining avian productivity are more complex than often appreciated, and that universal relationships between fragmentation and nest predation are unlikely.

Conservation strategies should therefore be uniquely tailored to a specific geographic region and should be based both on life history attributes represented in the community of interest and expected landscape changes. In this document, we develop a first step toward conservation of a low elevation riparian system in the Northern Rocky Mountains with the expected perturbation of bank stabilization. This document fulfills the following two objectives: (1) to compile data on the distribution, abundance, life histories, and habitat associations of birds, herptiles, and mammals along the upper Yellowstone River including species of interest (Table 1) that are riparian-dependent; and (2) to develop a matrix that helps managers evaluate the degree to which a species may be negatively affected by river bank stabilization activities. It is our intent that this document will provide preliminary guidance until the results of the above-mentioned investigation are available.

It is beyond the scope of this document to prioritize species by threat of extinction, or to lay out specific strategies for maintaining biodiversity of riparian forests. For recent in-depth examples of systematic approaches to species prioritization, maintaining biodiversity in dynamic forested landscapes, or maintaining ecosystem processes, see Millsap et al. (1990), Hansen et al. (1992, 1999), Hunter et al. (1993), Mace and Collar (1995), and White et al. (1997). 


\section{Methods}

This document contains species accounts for 69 bird species, 4 amphibian species, 5 reptile species, and 9 species of mammals known or assumed to occur in the study area, including the 38 species of interest (Table 1). Common and scientific names of birds are consistent with the American Ornithologists' Union (1998); bird species accounts are presented in taxonomic order. Latin names of species are presented in the species accounts (Appendix 1).

\section{Birds}

The bird species accounts consist of five sections: occurrence, abundance, diet, key habitat associations, and comments. Occurrence contains four levels of information on species occurrence in and around the study site. P. D. Skaar (Ellis et al. 1996) devised the method of using latilongs for plotting bird distribution. Latilongs are geographic areas defined by quadrants of latitude and longitude, each block measuring approximately 50 $x 70$ miles. The upper Yellowstone River occurs within the "Livingston latilong." For each species, we report season of occurrence and breeding status for the Livingston latilong and the adjacent latilongs to the west, south, north, and east, based on Johnsgard (1986) and Ellis et al. (1996). No Breeding Bird Survey (BBS) routes occur in the Livingston latilong (USGS Patuxent Wildlife Research Center 2000). Second, we report dates of Montana occurrence if the species is not a year-round resident. Dates of Wyoming occurrence are given when Montana dates are unavailable. Third, we report Montana egg records when available; otherwise, Wyoming or Colorado egg records are reported. Fourth, we report breeding status for the four quarter latilongs contained within the Livingston latilong (Fig. 1). Each quarter latilong (QLL) is represented by a letter: A (top left), B (top right), $C$ (bottom left), and $D$ (bottom right). The study site bisects QLL A and C.

The predicted Abundance of each species was generally categorized as abundant, common, uncommon, or rare according to Sauer et al. (2000). Numbers of individuals along BBS routes and Christmas Bird Counts in south-central Montana formed the basis for the categories; species with 11 to 30 individuals were considered abundant, 2 to 10 as common, 1 as uncommon, and none as rare. Diet is reported as primary, secondary, and tertiary food items. If the species' diet changes throughout the year, we report food items of the breeding season as primary. Notes relevant to diet are included.

Under Key habitat associations, we categorize species according to the degree of association with riparian habitats as: riparian obligate (only found in riparian habitats, except for migration), riparian associate (often found in riparian habitat, but regularly occurs elsewhere), occasional use of riparian habitats (occurs in riparian habitats, but generally occurs in other habitats), or limited use of riparian habitats (occurrence in riparian habitats is rare). These designations were based on foraging and breeding habitat associations described in various cited species accounts and references, including Johnsgard (1986), Ehrlich et al. (1988), Hutto and Young (1999), and Montana Partners In Flight (2000). Foraging describes the major habitat features where the species forages, including vegetation structure and non-vegetational features, such as presence of water (river, pond, lake, etc.) and human dwellings. For neotropical migrants, we describe only the breeding season habitat. For some species, we report "primary vegetation cover types in Wyoming," which are the top one to four cover types measured in hectares (Wyoming Bioinformation Node's Species Atlas 1999). Breeding describes the major features of the breeding habitat (if it differs from foraging habitat) and nests. Elevation ranges are from Wyoming records; if no state-wide record was available for the upper range of elevation, $3,000 \mathrm{~m}$ was assumed (Wyoming Bioinformation Node's Species Atlas 1999).

Under Comments, we note if the upper Yellowstone River is near an edge of a species' range of occurrence. We note if the species has been designated as a species of interest by the Technical Advisory Committee to the Upper Yellowstone River Task Force, the priority status assigned by Montana Partners In Flight (2000), and if the species is at high risk of extinction in the Greater Yellowstone Ecosystem, based on work done in the upper Gallatin, Madison, and Henry's Fork watersheds in Montana, Idaho, and Wyoming (Hansen et al. 1999). Other notes about the species relevant to the project are included.

We constructed a matrix of birds and various attributes, including occurrence and predicted abundance in the Livingston latilong, the season of occurrence, the association with riparian habitats, indication of patch size relationships, edge of range, indicators of population trends (from local and continental BBS trends (Sauer et al. 2000), and risk of extinction in the Greater Yellowstone Ecosystem (Hansen et al. 1999). 
Table 1. List of species of interest developed by the Technical Advisory Committee to the Upper Yellowstone River Task Force using criteria of Partners In Flight, U.S. Fish and Wildlife Service, and the state of Montana. One mammal species (in brackets) was added to the list by authors.

\section{Birds}

\author{
American White Pelican (Pelecanus erythrorhynchos) \\ Trumpeter Swan (Cygnus buccinator) \\ Harlequin Duck (Histrionicus histrionicus) \\ Bald Eagle (Haliaeetus leucocephalus) \\ Northern Goshawk (Accipiter gentilis) \\ Peregrine Falcon (Falco peregrinus) \\ Sage Grouse (Centrocercus urophasianus) \\ Black-billed Cuckoo (Coccyzus erythropthalmus) \\ Great Gray Owl (Strix nebulosa) \\ Boreal Owl (Aegolius funereus)
}

Lewis' Woodpecker (Melanerpes lewis) Black-backed Woodpecker (Picoides ancticus) Willow Flycatcher (Empidonax traillii) Least Flycatcher (Empidonax minimus) Hammond's Flycatcher (Empidonax hammondii) Cordilleran Flycatcher (Empidonax occidentalis) Red-eyed Vireo (Vireo olivaceus) Veery (Catharus fuscescens) Sage Thrasher (Oreoscoptes montanus) MacGillivrays Warbler (Oporornis tolmiei)

Amphibians

Tiger salamander (Ambystoma tigrinum)

Boreal (western) toad (Bufo boreas)
Western chorus frog (Pseudacris triseriata) Spotted frog (Rana pretiosa)

Reptiles

Sagebrush lizard (Scleroporus graciosus) Rubber boa (Charina bottae) Racer (Coluber constrictor)

Mammals

[Water shrew (Sorex palustris)]

Preble's shrew (Sorex preblei)

Fringed myotis (Myotis thysanodes)

Townsend's big-eared bat (Corynorhinus townsendii) Grey wolf (Canis lupis)
Lynx (Lynx lynx)

Wolverine (Gulo gulo)

Grizzly bear (Ursus arctos)

Uinta chipmunk (Tamias umbrinus)
Western garter snake (Thamnophis elegans)

Western rattlesnake (Croatalus viridis) 


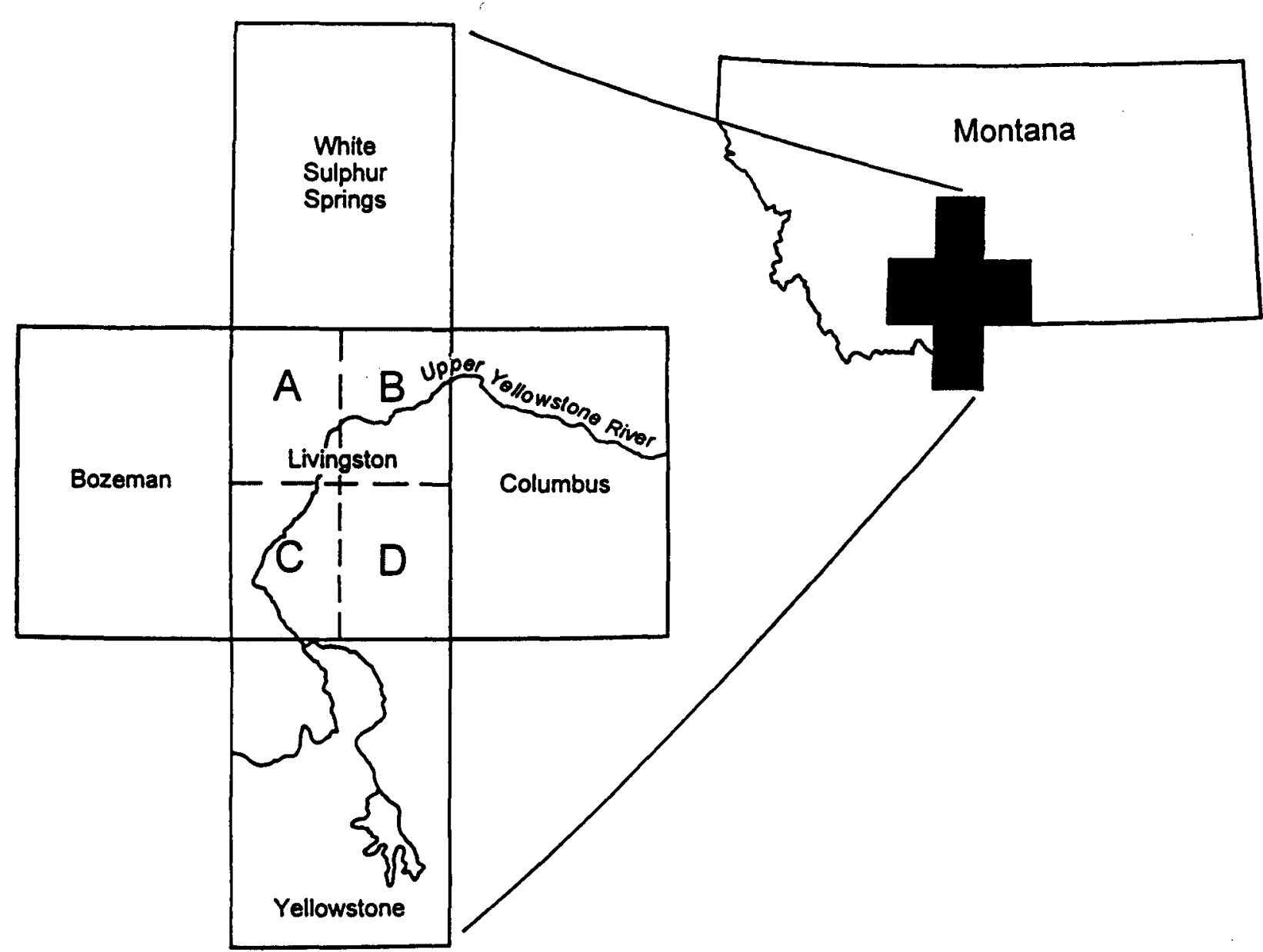

Fig. 1. The location of the upper Yellowstone River and five latilong blocks for which species occurrence data are provided. Within the Livingston latilong, quarter latilongs (QQL) A-D are designated. The upper Yellowstone River study area occurs in QQL $A$ and $C$ of the Livingston latilong.

We identified mechanisms (factors) by which species would be sensitive to stream bank stabilization changes, including declines in fish populations, changes in stream morphology (for example, the disappearance of shallow water pools for foraging or disruption of bank morphology for nest construction), simplification of riparian vegetation structure (loss of riparian trees over time with no cottonwood regeneration and subsequent loss of the shrub layer), and decline in insect populations. These changes would occur over different time scales. For example, changes to fish populations and stream morphology would happen quickly, within a few years. Changes to the canopy structure and shrub understory would occur over several years and decades.
Finally, we predicted the degree of vulnerability to bank stabilization activities on the upper Yellowstone River. Vulnerability to Bank Stabilization Activities (VBSA) was scored as follows. Species that would suffer because of declines in fish populations and/or changes in stream morphology and that were riparian obligates or associates were scored as 5 . Species susceptible to a decline of shrub understory were scored based on the assumption that adequate understory structure existed at the time of stabilization activities, and the changes would occur over several decades (see Discussion). The species were scored as follows: riparian obligates - 5; associates - 4; occasional users -3 ; and limited users 2. Species susceptible to a decline in riparian trees were 
scored as: associates -4 ; occasional users -3 ; and limited users -2 . These decisions were based on the assumption that loss of cottonwood trees would occur over decades as present day trees age and die, and that replacement stands are influenced by bank stabilization.

\section{Amphibians, Reptiles, and Mammals}

The species accounts consist of five sections: occurrence, abundance, diet, key habitat associations, and pertinent comments. We added one species that was not included on the original list of species of interest, the water shrew (Sorex palustris). This mammal may be of critical interest because of its close tie to rivers and stream banks.

Thompson (1982) and Montana Natural Resources Information System (2000) were used to document occurrence of herpetofauna and mammals of interest in the upper Yellowstone River area. Several categories of latilong information are presented in Thompson (1982), including $S$ (specimen deposited in a university or nationally recognized museum), $\mathrm{V}$ (visual or auditory evidence, including specimens not deposited, photographs, tracks, signs, etc.), and L (records probably referring to the latilong, but possibly belonging to an adjacent latilong; e.g., specimens with only a county name where that county is in one or more latilongs).

Abundance was determined from Flath (1984) and Clark et al. (1989). Global and state-wide conservation status, ranked according to a standardized procedure used by all Natural Heritage Programs (Association for Biodiversity Information 2000), are provided for all amphibian, reptile, and mammal species. See page 15 for code definitions.

Our approach to building species descriptions differs from that for birds because there are no comprehensive accounts of habitat requirements for reptiles or amphibians. We used a variety of sources in collecting information about diets and key habitat associations, including the Montana Natural Resources Information System (2000), species accounts published by The American Society of Mammalogists, Wilson and Ruff (1999), peer reviewed literature, and government publications. When information specific to the upper Yellowstone River area of interest or Montana was not available, information on habitat, diet preferences, and species life history was collected for the nearby states of Idaho, Wyoming, and/or Colorado. We categorized species as riparian obligates, riparian associates, or limited use of riparian habitats, as for birds above.

A matrix of herpetofauna, mammals, and various attributes was constructed, and included occurrence, season of occurrence, association with riparian habitats, indication of patch size relationships, edge of range, and conservation status. We identified mechanisms (factors) by which species would be sensitive to streambank stabilization changes as above for birds. Finally, we predicted the degree of vulnerability to bank stabilization activities on the upper Yellowstone River.

\section{Results and Discussion}

In this document, we ascertain, in the most general sense, the likelihood that common bank stabilization activities, such as riprapping and building dikes and jetties, will result in habitat changes for a suite of species. Clearly, the only way to precisely identify the responses of vertebrates to specific stream flow disturbances is to conduct intensive field investigations; such efforts are outside the scope of this document. The degree to which an animal specializes in a particular habitat will influence the likelihood of local extinction given perturbation to that habitat. We therefore focus on the degree of association with riparian habitats in evaluating the level of vulnerability to habitat change.

Habitats can be altered in many ways. Construction will directly alter river bank structure at the site of the activity, and changes in water velocity at the bank/water interface can result in alterations to channel morphology and water temperatures. Fish and amphibian populations may decline or be re-distributed in response to these changes, and the availability of fish may be reduced for foraging vertebrates. These changes will probably occur quickly, within a few years at most. Because home ranges of amphibians, reptiles, and small mammals are small, the effects of dike/riprap construction on these taxa may be immediate because of the rapid loss of vegetation and insect biomass at the site of construction.

Bank protection such as riprap and barbs could also result in changes to the structure of riparian vegetation across several decades. The structural complexity of western riparian forests is strongly influenced by flowrelated geomorphic processes necessary for establishment of new cottonwood and willow patches (Bradley and Smith 1986, Scott et al. 1996, Friedman et al. 1997). For example, riparian stands along the upper Missouri 
River, Montana, originate after infrequent floods position cottonwood seedlings on narrow alluvial deposits above the zone of frequent scour by ice and water (Smith 1980, Scott et al. 1997, Auble and Scott 1998). By limiting the natural erosional and deposition processes, bank protection activities could alter the pattern and distribution of sites of freshly deposited sediments that serve as seedbeds for cottonwoods and willows.

Plant succession along the upper Yellowstone River is probably similar to succession along the lower Yellowstone River as described by Boggs and Weaver (1994), although the rates may differ. In general, community dominance progresses from seedlings of Great Plains cottonwoods (Populus deltoides) and sandbar willow (Salix exigua) to thickets of cottonwoods and willows, to cottonwood forests, to shrubs, and finally to grassland. Structural diversity of semiarid riparian forests reaches a maximum after approximately 90 years with the development of a mature cottonwood canopy and shrub understory. Shrubs persist for 50 years or more after the attrition of mature cottonwoods; the longevity of understory shrubs, however, is not well documented. In the absence of fluvial disturbances, riparian succession terminates in grassland (Hansen et al. 1991, Boggs and Weaver 1994, Friedman et al. 1997).

Finally, as the volume of riparian vegetation declines with the senescence of cottonwoods and the disappearance of shrubs, the biomass of arthropods could also decline. Blenden et al. (1984) documented a positive relationship between arthropod biomass and biomass of forb and woody vegetation.

\section{Birds}

Accounts of species occurrence, abundance, and life history traits of 69 bird species are detailed in Appendix 1. Of the 69 bird species, 6 are classified as abundant, 35 as common, 23 as uncommon, and 5 as rare in the study region; these assignments assume that suitable habitat exists. Thirteen bird species are classified as riparian obligates, 23 as riparian associates, 24 as occasional users of riparian habitats, and 9 as limited users of riparian habitats. Some bird species, such as Ruffed Grouse, Ovenbirds, and Brown-headed Cowbirds, are more closely tied to riparian habitats in the semiarid landscapes of Montana than in more mesic regions within their ranges. Most birds (41 species) are summer residents, and 26 species occur year-round (Table 2). Thirty-four bird species are strongly associated with shrub or shrub-understory habitats (Table 2), and nine species are associated with large habitat patches. Twenty- one species are at the edge of their breeding ranges in the upper Yellowstone River valley.

Local trends (Sauer et al. 2000) indicate possible declines (codes 5 and 4 ) in 26 species, population stability (codes 3 and 2) in 10 species, and possible increases (code 1) in 22 species. Continental population trends of 19 species are significantly declining, 32 are stable, and 14 increasing. Twenty of the 69 species are considered "at most risk of extinction in the Greater Yellowstone Ecosystem" (Hansen et al. 1999). These species primarily inhabit lower elevation deciduous forests of cottonwood, willow, and aspen. Hansen et al. (1999) propose a management strategy directed to restoring deciduous forest habitats, which includes the recommendation that river bank stabilization be discouraged.

Avian species that are riparian obligates are the birds most vulnerable to bank stabilization activities (Table 2). Belted Kingfishers would suffer if fish populations decline. Harlequin Ducks, Spotted Sandpipers, and American Dippers would be negatively influenced by changes in stream morphology, especially the loss of shallow water and braided channels. These effects would likely occur relatively soon (within years) after stream flow perturbations. Willow Flycatchers, Red-eyed Vireos, Yellow Warblers, American Redstarts, Northern Waterthrushes, Common Yellowthroats, Wilson's Warblers, Song Sparrows, and Lincoln's Sparrows would be negatively affected if stream flow changes resulted in eventual (within decades) reductions in the extent of shrub understory. Of the 16 species $(23.2 \%)$ ranked as highly vulnerable (code 5), 13 are riparian obligates. The additional three species are riparian associates expected to decline with declines in fish populations (American White Pelicans and Bald Eagles) or changes in stream morphology (Trumpeter Swans and Bald Eagles).

Twenty (29.0\%) of the 69 bird species are considered very likely at risk from bank stabilization activities (code 4). They are all riparian associates, most (14) of which would suffer habitat loss with a decline in shrub understory structure, and six would emigrate with an eventual loss of riparian trees.

We classified 17 species as being somewhat vulnerable to stream flow perturbations (code 3); all use riparian occasionally. These species, including flycatchers and woodpeckers, would suffer some degree of habitat loss if understory structure declined or riparian trees eventually disappeared. Most (78.9\%) of the 19 bird species that we expect to be influenced the least by bank stabilization activities (codes 1 and 2) use riparian 
Table 2. Matrix of bird species by various attributes, including occurrence, abundance, association with riparian habitats, population trends, risk factors over time, and vulnerability to bank stabilization activities (VBSA). Code definitions follow the table.

\begin{tabular}{|c|c|c|c|c|c|c|c|c|c|c|c|c|c|}
\hline Species & $\begin{array}{l}\text { Presence } \\
\text { known }\end{array}$ & $\begin{array}{l}\text { Predicted } \\
\text { abundance }\end{array}$ & Season & $\begin{array}{l}\text { Assoc w/ } \\
\text { riparian }\end{array}$ & $\begin{array}{l}\text { Assoc w/ } \\
\text { shrubs }\end{array}$ & $\begin{array}{r}\text { Assoc w/ } \\
\text { large patch }\end{array}$ & $\begin{array}{l}\text { Edge of } \\
\text { range? }\end{array}$ & $\frac{B}{\text { Local }}$ & $\frac{\text { BS trends }}{\text { Continental }}$ & $\begin{array}{c}\text { At most } \\
\text { risk } \\
\text { (GYE) }\end{array}$ & $\begin{array}{l}\text { Risk } \\
\text { factors }\end{array}$ & $\begin{array}{c}\text { Time } \\
\text { scale }\end{array}$ & VBSA \\
\hline American White Pelican ${ }^{\mathrm{i}}$ & 1 & common & Su,Mi & assoc & & & & 1 & incr & & $\mathbf{F}$ & years & 5 \\
\hline Trumpeter Swan i & 1 & common & Su, Wi,Mi & assoc & & & & $\ldots$ & - & & SM, $V_{a}$ & years & 5 \\
\hline Harlequin Duck ${ }^{i}$ & 1 & uncommon & Su & oblig & 2 & & yes & - & - & & $S M, V_{s}$ & years & 5 \\
\hline Bald Eagle ${ }^{i}$ & 1 & uncommon & Su, Wi & assoc & & & yes & 1 & incr & & $F, S M, V_{t}$ & years & 5 \\
\hline Northern Goshawk ${ }^{i}$ & I & uncommon & Yr & limited & & & yes & 5 & stable & & & & 1 \\
\hline American Kestrel & 1 & common & Su; Yr & occas & & & & 4 & stable & & & & 1 \\
\hline Peregrine Falcon ${ }^{i}$ & 1 & rare & Yr & limited & & & - & & stable & & & & 1 \\
\hline Rufted Grouse & 1 & uncommon & $\mathbf{Y r}_{\mathbf{r}}$ & assoc & & & yes & 5 & stable & yes & $V_{2}$ & & 4 \\
\hline Sage Grouse ${ }^{i}$ & 1 & uncommon & $\mathbf{Y}_{\mathbf{r}}$ & limited & & & & 5 & stable & & & & 1 \\
\hline Spolled Sandpiper & 1 & common & Su & oblig & & & & 1 & stable & & SM,I & years & 5 \\
\hline Mourning Dove & 1 & abundant & Su;Yr & occas & & & & 2 & decl & & & & 1 \\
\hline Black-billed Cuckoo' & 1 & uncommon & Su & assoc & 2 & & yes & 5 & decl & & $V_{2}$ & decades & 4 \\
\hline Great Gray Owl & 1 & rare & Yr & limited & & & yes & - & - & & & & 1 \\
\hline Boreal Owl & 0 & rare & Vagr & limited & & & yes & - & - & & & & 1 \\
\hline Belted Kingfisher & 1 & uncommon & $\mathrm{Yr}$ & oblig & & & & 5 & decl & & F,SM & years & 5 \\
\hline Lewis' Woodpecker' & 1 & rare & Su & limited & 1 & & yes & $\cdots$ & stable & & $V_{s}$ & decades & 2 \\
\hline Red-naped Sapsucker & 1 & uncommon & Su & occas & & & yes & 1 & stable & yes & $v_{1}$ & decades & 3 \\
\hline Downy Woodpecker & 1 & uncommon & Yr & occas & 1 & & & 2 & stable & & $v_{1}, v_{3}$ & decades & 3 \\
\hline Black-backed Woodpecker ${ }^{i}$ & 1 & rare & $\mathrm{Yr}_{\mathbf{r}}$ & limited & & & yes & $\cdots$ & stable & yes & $v_{1}$ & decades & 2 \\
\hline Northern Flicker & 1 & common & Su, Yr & occas & & & & 4 & decl & & $v_{1}$ & decades & 3 \\
\hline Olive-sided Flycatcher & 1 & uncommon & Su & occas & & & yes & 5 & decl & yes & $V_{1}, I$ & decades & 3 \\
\hline Western Wood-pewee & 1 & common & Su & assoc & 1 & & & 2 & decl & yes & $V_{3}, I$ & decades & 4 \\
\hline Willow Flycatcher & 1 & uncommon & Su & oblig & 2 & & & 1 & stable & yes & $v_{3}$ & decades & 5 \\
\hline Least Flycatcher' & 1 & common & $\mathrm{Su}$ & assoc & 1 & yes & & 2 & decl & yes & $\mathrm{V}_{3}$ & decades & 4 \\
\hline Hammond's Flycatcher' & 1 & uncommon & Su & occas & & & yes & 5 & stable & yes & $v_{1}$ & decades & 3 \\
\hline Dusky Flycatcher & 1 & common & Su & occas & 2 & yes & & 1 & stable & yes & $\mathbf{v}_{\mathbf{s}}$ & decades & 3 \\
\hline Cordilleran Flycatcher' & 1 & uncommon & Su & assoc & & & & 5 & stable & & $v_{t}$ & decades & 4 \\
\hline Eastern Kingbird & 1 & common & Su & assoc & & & & 1 & decl & & $v_{t}$ & decades & 4 \\
\hline Plumbeous Vireo & 1 & uncommon & $\mathrm{Su}$ & occas & & & & 1 & incr & & $v_{t}$ & decades & 3 \\
\hline Warbling Vireo & 1 & common & Su & assoc & & yes & & 4 & incr & & $v_{t}$ & decades & 4 \\
\hline
\end{tabular}




\begin{tabular}{|c|c|c|c|c|c|c|c|c|c|c|c|c|c|}
\hline Species & $\begin{array}{l}\text { Presence } \\
\text { known }\end{array}$ & $\begin{array}{l}\text { Predicted } \\
\text { abundance }\end{array}$ & Season & $\begin{array}{l}\text { Assoc w/ } \\
\text { riparian }\end{array}$ & $\begin{array}{l}\text { Assoc w/ } \\
\text { shrubs }\end{array}$ & $\begin{array}{c}\text { Assoc w/ } \\
\text { large patch }\end{array}$ & $\begin{array}{l}\text { Edge of } \\
\text { range? }\end{array}$ & \multicolumn{2}{|c|}{$\frac{\text { BBS trends }}{\text { Local Continental }}$} & $\begin{array}{l}\text { At most } \\
\text { risk } \\
\text { (GYE) }\end{array}$ & $\begin{array}{l}\text { Risk } \\
\text { factors }\end{array}$ & $\begin{array}{c}\text { Time } \\
\text { scale }\end{array}$ & VBSA \\
\hline Red-eyed Vireo ${ }^{i}$ & 1 & uncommon & Su & oblig & 2 & & yes & 3 & incr & & $\mathrm{V}_{3}$ & decades & 5 \\
\hline Black-billed Magpie & 1 & common & Yr & assoc & 2 & & & 5 & stable & & $v_{s}$ & decades & 4 \\
\hline American Crow & 1 & common & $Y_{I}$ & occas & & & & 1 & incr & & & & 1 \\
\hline Black-capped Chickadee & 1 & common & Yr & assoc & 1 & & & 1 & incr & & $V_{1}$ & decades & 4 \\
\hline House Wren & 1 & abundant & Su & assoc & 1 & yes & & 1 & incr & & $V_{3}$ & decades & 4 \\
\hline American Dipper & 1 & common & Su,Wi & oblig & & & & 1 & stable & & $\mathrm{SM}, \mathrm{I}_{\mathrm{a}}$ & years & $s$ \\
\hline Ruby-crowned Kinglet & & abundant & Su & occas & & & & 2 & stable & & $V_{1}$ & decades & 3 \\
\hline Veery $^{i}$ & 1 & common & Su & assoc & 2 & yes & & 4 & decl & yes & $V_{3}$ & decades & 4 \\
\hline Swainson's Thrush & 1 & common & Su & occas & 2 & & yes & 1 & stable & & $\mathrm{V}_{\mathrm{s}}$ & decades & 3 \\
\hline American Robin & 1 & abundant & Su, Yr & assoc & & & & 4 & incr & & $V_{1}$ & & 4 \\
\hline Gray Catbird & 1 & common & $\mathrm{Su}$ & assoc & 2 & yes & & 3 & decl & & $V_{8}$ & decades & 4 \\
\hline Sage Thrasher' & 1 & uncommon & Su & limited & 2 & & & 1 & stable & & & & 1 \\
\hline Cedar Waxwing & 1 & common & Yr & assoc & 1 & & & 1 & incr & yes & $\mathrm{V}_{3}$ & decades & 4 \\
\hline Orange-crowned Warbler & 1 & uncommon & Su & occas & 2 & & yes & 5 & decl & yes & $\mathrm{V}_{\mathrm{s}}$ & decades & 3 \\
\hline Yellow Warbler & 1 & abundant & Su & oblig & 2 & & & 1 & incr & & $V_{s, 1}$ & decades & 5 \\
\hline Yellow-rumped Warbler & 1 & abundant & Su,Mi & occas & & yes & & 4 & incr & & 1 & decades & 2 \\
\hline American Redstart & 1 & uncommon & Su & oblig & 2 & yes & yes & 5 & stable & yes & $V_{3}$ & decades & 5 \\
\hline Ovenbird & $i$ & rare & Su & assoc & & yes & yes & -. & incr & & $v_{t}$ & decades & 4 \\
\hline Northern Waterthrush & 1 & uncommon & Su & oblig & 2 & & yes & - & stable & yes & $v_{s}$ & decades & $s$ \\
\hline MacGillivray's Warbler' & 1 & common & Su & assoc & 2 & & & 4 & stable & yes & $v_{s}$ & decades & 4 \\
\hline Coinmon Yellowthroat & 1 & common & $\mathrm{Su}$ & oblig & 2 & & & 1 & decl & yes & $v_{3}$ & decades & 5 \\
\hline Wilson's Warbler & 1 & uncommon & Su & oblig & 2 & & yes & $\ldots$ & decl & yes & $v_{s, 1}$ & decades & 5 \\
\hline Yellow-breasted Chat & 1 & common & Su & assoc & 2 & & & 1 & stable & & $\mathrm{V}_{8}$ & decades & 4 \\
\hline Western Tanager & & common & $\mathrm{Su}$ & occas & & & & 1 & stable & & $v_{t}$ & decades & 3 \\
\hline Green-tailed Towhee & & common & $\mathrm{Su}$ & occas & 2 & & & 4 & stable & & $V_{s}$ & decades & 3 \\
\hline Spotted Towhee & & abundant & $\mathbf{S u}$ & occas & 2 & & & 3 & stable & yes & $v_{8}$ & decades & 3 \\
\hline Chipping Sparrow & & abundant & Su & cocas & 2 & & & 4 & stable & & $v_{8}$ & decades & 3 \\
\hline Brewer's Sparrow & 1 & common & Su & limited & 2 & & & 5 & decl & yes & & & 1 \\
\hline Fox Sparrow & 1 & uncommon & $\mathrm{Yr}$ & assoc & 2 & & yes & - & stable & & $V_{3}$ & decades & 4 \\
\hline
\end{tabular}




\begin{tabular}{|c|c|c|c|c|c|c|c|c|c|c|c|c|c|}
\hline Species & $\begin{array}{c}\text { Presence } \\
\text { known }\end{array}$ & $\begin{array}{l}\text { Predicted } \\
\text { abundance }\end{array}$ & Season & $\begin{array}{r}\text { Assoc w/ } \\
\text { riparian }\end{array}$ & $\begin{array}{r}\text { Assoc w/ } \\
\text { shrubs }\end{array}$ & $\begin{array}{l}\text { Assoc w/ } \\
\text { large patch }\end{array}$ & $\begin{array}{l}\text { Edge of } \\
\text { range? }\end{array}$ & $\frac{B}{\text { Local }}$ & $\frac{\text { BS trends }}{\text { Continental }}$ & $\begin{array}{l}\text { At most } \\
\text { risk } \\
\text { (GYE) }\end{array}$ & $\begin{array}{l}\text { Risk } \\
\text { factors }\end{array}$ & $\begin{array}{l}\text { Time } \\
\text { scale }\end{array}$ & VBSA \\
\hline $\begin{array}{l}\text { Song Sparrow } \\
\text { Lincoln's Sparrow } \\
\text { White-crowned Sparrow } \\
\text { Black-headed Grosbeak } \\
\text { Lazuli Bunting }\end{array}$ & $\begin{array}{l}1 \\
1 \\
1 \\
1\end{array}$ & $\begin{array}{l}\text { common } \\
\text { common } \\
\text { common } \\
\text { common } \\
\text { common }\end{array}$ & $\begin{array}{l}\text { Yr } \\
\text { Su, Yr } \\
\text { Su;Yr } \\
\text { Su } \\
\text { Su }\end{array}$ & $\begin{array}{l}\text { oblig } \\
\text { oblig } \\
\text { occas } \\
\text { occas } \\
\text { occas }\end{array}$ & $\begin{array}{l}2 \\
2 \\
2 \\
2 \\
2\end{array}$ & & & $\begin{array}{l}4 \\
1 \\
4 \\
1 \\
2\end{array}$ & $\begin{array}{l}\text { decl } \\
\text { incr } \\
\text { decl } \\
\text { stable } \\
\text { stable }\end{array}$ & & $\begin{array}{l}v_{3} \\
v_{3} \\
v_{3} \\
v_{3} \\
v_{3}\end{array}$ & $\begin{array}{l}\text { decades } \\
\text { decades } \\
\text { decades } \\
\text { decades } \\
\text { decades }\end{array}$ & $\begin{array}{l}5 \\
5 \\
3 \\
3 \\
3\end{array}$ \\
\hline $\begin{array}{l}\text { Brown-headed Cowbird } \\
\text { Bullock's Oriole } \\
\text { Cassin's Finch } \\
\text { Red Crossbill } \\
\text { American Goldrinch }\end{array}$ & $\begin{array}{l}1 \\
1 \\
1 \\
1 \\
1\end{array}$ & $\begin{array}{l}\text { abundant } \\
\text { common } \\
\text { common } \\
\text { common } \\
\text { common }\end{array}$ & $\begin{array}{l}\text { Su } \\
\text { Su } \\
\text { Su;Yr } \\
\text { Su;Yr } \\
\text { Su;Yr }\end{array}$ & $\begin{array}{l}\text { occas } \\
\text { assoc } \\
\text { occas } \\
\text { occas } \\
\text { assoc }\end{array}$ & 2 & & yes & $\begin{array}{l}2 \\
1 \\
5 \\
2 \\
4\end{array}$ & $\begin{array}{l}\text { decl } \\
\text { decl } \\
\text { stable } \\
\text { stable } \\
\text { decl }\end{array}$ & yes & $V_{1}$ & decades & $\begin{array}{l}1 \\
4 \\
2 \\
2 \\
4\end{array}$ \\
\hline
\end{tabular}

\section{Species}

\section{Codes}

iDesignated as species of interest by the Technical Advisory Committee to the Upper Yellowstone River Task Force.

\section{Presence known}

1 - presence documented in either Livingston latilong or adjacent block. Bold means that breeding is confirmed in the Livingston latilong.

Predicted abundance (assuming that suitable habitat exists)

Abundant - 11 to 30 individuals counted per Breeding Bird Survey route in the vicinity of the Livingston latilong (Sauer et al. 2000)

Common -2 to 10 individuals counted

Uncommon -1 individual counted

Rare - none counied

Season - Bold indicates the season of greatest expected abundance

\section{Su - summer/breeding season}

Wi - winter

Mi - migration

Yr - year-round

\section{Association with riparian habitats}

Riparian obligate (oblig) - occurs only in riparian habitats 


\section{Codes (concluded)}

Riparian associate (assoc) - often found in riparian habitats, but regularly occurs elsewhere

Occasional use of riparian habitats (occas) - occurs in riparian habitats, but generally occurs in other habitats

Limited use of riparian habitats (limited) - occurrence in riparian habitats is rare

Association with large patch - species known to associate with large patches or to be forest-interior associates (Temple 1986, Hansen et al. 1993, Saab 1999).

Association with shrubs or shrubby understory

2 - shrubs important microhabitat feature of nesting/foraging habitat; 1 - associated with understory

\section{BBS trends}

Local - percent change per year

$5-<-1.5$ (declining)

$4--1.5$ to -0.25

$3--0.25$ to +0.25 (stable)

$2-+0.2510+1.5$

$1->1.5$

Continental [statistical results available in Sauer et al. (2000)]

Species were coded as:

declining; either $S$ or 4 with $P<0.10$

stable; change either - or + but not statistical significance

increasing; 1 or 2 with $P<0.10$

At most risk (GYE) - designated at most risk of extinction in the Greater Yellowstone Ecosystem (GYE) by Hansen et al. (1999).

Risk factors; vulnerability contingent upon modification of factors

F - decrease in fish populations

$S M$ - strearn habitat and morphology

$V$ - riparian vegetation $\left(V_{t}=\right.$ susceptible to loss of trees, $V_{3}=$ susceptible to loss of shrubby understory, $V_{a}=$ susceplible to loss of aquatic vegetation)

1 - susceptible to decline in insect populations $\left(I_{2}=\right.$ aquatic insects)

Time scale - period of time over which negative effects of bank stabilization would appear. Years - within months or a few years; decades - over a much longer period of time, a few to many decades.

\section{Vulnerability to bank stabilization activities (VBSA)}

5 - Highly vulnerable

4 - Very likely at risk

3 - Somewhat at risk

2 - Probably little risk

1 - No, low risk 
habitats only on a limited basis; eight of these were regarded as species of interest (Table 3 ).

In summary, we believe that the degree of vulnerability of birds to bank stabilization activities and changes in stream flow is strongly related to the degree to which the species is tied to riparian habitats (Table 3 ). Bird species that are most vulnerable are either riparian obligates or riparian associates. Furthermore, species that are affected by changes in fish populations and stream morphology would suffer more rapid changes than species affected primarily by changes in riparian vegetation (either understory or trees), which would occur over a much longer period of time.

It is well known that structural complexity of forests can have important influences on avian abundance and composition (MacArthur et al. 1962, Willson 1974, Brinson et al. 1981). Scott et al. (in review) demonstrate that structurally complex cottonwood-shrub forest patches host a more diverse community of birds at greater abundances and densities than stands of old cottonwoods with little understory.

\section{Amphibians and Reptiles}

Many reptiles and some life stages of amphibians depend on dew or temporary water sources, such as ephemeral ponds or puddles, for moisture more so than permanent water, such as rivers. However, through their prey, these animals may be more closely linked to riparian areas than it appears from their life history and habitat information alone. Frogs and toads in Montana generally need lentic water in order to breed, deposit eggs, and provide suitable habitat for developing eggs, larvae, and metamorphose. As adults, most toads are not as closely tied to water and use drier, upland habitats.

The four amphibian species considered here are riparian obligates that require water for breeding and larval development. All have high-predicted vulnerabilities to bank stabilization activities that would affect backwater areas, ponds, and other bodies of non-flowing water (Table 4). Tiger salamanders and boreal toads are associated with a variety of habitats in which still waters occur. Western chorus frogs are associated with a variety of habitats containing either moving or still water, and spotted frogs are closely associated with permanent quiet waters.

Effects of stream flow perturbations would occur relatively fast with changes in stream bank morphology and aquatic vegetation. Changes in water temperature regimes concurrent with flow perturbations and/or morphological changes could adversely affect amphibians. Water temperature is a primary determinant of developmental time in amphibian eggs and larvae (Duellman and Trueb, 1986:167-169). In general, warmer temperatures accelerate development but temperatures over maxima particular to each species can cause death. Cold temperatures retard or preclude development and can have major effects on recruitment. For example, toad larvae that metamorphose late in the summer because of cold-water temperatures may have difficulty gaining enough mass and finding appropriate hibernacula before first frosts.

Three of the five reptiles, the rubber boa, racer, and western garter snake, are riparian associates with high predicted vulnerabilities to bank stabilization activities. They are often found in streamside grassy areas, hiding under rotting logs and rocks. Effects of stream flow perturbations would occur relatively fast with changes in stream bank morphology and to the terrestrial groundoover. Sagebrush lizards and western rattlesnakes make limited use of riparian habitats and would be less affected by stream flow perturbations. They would primarily be affected by elimination of thick brushy areas associated with rocky ledges and outcroppings.

\section{Mammals}

The only mammal species that would be highly vulnerable to bank stabilization activities is a riparian obligate, the water shrew, usually found within a meter of water (Table 4). In Montana, the water shrew occurs near open moving water on streambanks with heavy vegetative cover, logs, rocks and boulders, tree roots, and crevices. The water shrew would be most affected by changes in bank morphology, aquatic vegetation, and insects.

The Preble's shrew uses riparian habitats only occasionally and would less likely be affected by stream flow changes.

Of the two bat species, the Townsend's big-eared bat is more closely associated with riparian habitats than the fringed myotis, although both species forage over water. Unless roosting sites are destroyed or exposed to greater levels of human activity, we anticipate the effects of bank stabilization activities would be minimal. The main threat, if any, would be reductions in the primary food source, insects such as beetles and lepidopterans.

The larger and more wide-ranging carnivores, such as the grey wolf, lynx, and wolverine, that occur along the upper Yellowstone River use the riparian corridor only occasionally as part of their larger home ranges. 
Table 3. Bird species categorized by predicted abundance along the upper Yellowstone River and association with riparian habitats. Species in all capitals and bold are those with a Vulnerability to Bank Stabilization Activities (VBSA) score of 5 (highly vulnerable). Species in bold italics have a VBSA score of 4 (very likely at risk), and those in italics have a VBSA score of 3 (somewhat at risk). Asterisks indicate that two of the three measures of population trends indicate declines. The three trends are the local BBS trend (4 or 5 indicates potential decline), BBS continental trend, or scored as "at most risk of extinction in the Greater Yellowstone Ecosystem" (Hansen et al. 1999). $i$ indicates species of interest as determined by the Technical Advisory Committee to the Upper Yellowstone River Task Force.

\begin{tabular}{|c|c|c|c|c|}
\hline Abundance & Riparian obligate & Riparian associate & Occasional use & Limited use \\
\hline Abundant & YELLOW WARBLER & $\begin{array}{l}\text { House Wren } \\
\text { American Robin }\end{array}$ & $\begin{array}{l}\text { Mourning Dove } \\
\text { Ruby-crowned Kinglet } \\
\text { Yellow-rumped Warbler } \\
\text { Spolled Towhee } \\
\text { Chipping Sparrow } \\
\text { Brown-headed Cowbird }\end{array}$ & \\
\hline Common & $\begin{array}{l}\text { SPOTTED SANDPIPER } \\
\text { AMERICAN DIPPER } \\
\text { "COMMON YELLOWTHROAT } \\
\text { "WILSON'S WARBLER } \\
\text { SONG SPARROW } \\
\text { LINCOLN'S SPARROW }\end{array}$ & $\begin{array}{l}\text { AMERICAN WHITE PELICAN' } \\
\text { TRUMPETER SWAN' } \\
\text { "Western Wood-pewwee } \\
\text { "Least Flycatcher' } \\
\text { Eastern Kingbird } \\
\text { Warbling Vireo } \\
\text { Black-billed Magpie } \\
\text { Black-capped Chickadee } \\
\text { "Veery" } \\
\text { Gray Casbird } \\
\text { Cedar Waxwing } \\
\text { "MacGillivray's Warbler' } \\
\text { Yellow-breasted Chat } \\
\text { Bullock's Oriole } \\
\text { "American Goldfinch }\end{array}$ & $\begin{array}{l}\text { American Kestrel } \\
\text { Downy Woodpecker } \\
\text { "Northern Flicker } \\
\text { Dusky Flycalcher } \\
\text { American Crow } \\
\text { Swainson' Thrush } \\
\text { Western Tanager } \\
\text { Green-lailed Towhee } \\
\text { "White-crowned Sparrow } \\
\text { Black-headed Grosbeat } \\
\text { Lazuli Bunting } \\
\text { Cassin's Finch } \\
\text { Red Crossbill }\end{array}$ & "Brewer's Sparrow \\
\hline Uncommon & $\begin{array}{l}\text { HARLEQUIN DUCK' } \\
\text { "BELTED KINGFISHER } \\
\text { WILLOW FLYCATCHER' } \\
\text { RED-EYED VIREO' } \\
\text { "AMERICAN REDSTART } \\
\text { NORTHERN WATERTHRUSH } \\
\text { WILSON'S WARBLER }\end{array}$ & $\begin{array}{l}\text { BALD EAGLE } \\
\text { Ruffed Grouse } \\
\text { "Bleck-billed Cuckooi } \\
\text { Cordilleran Flycalcheri } \\
\text { Fax Sparrow }\end{array}$ & $\begin{array}{l}\text { Red-naped Sapsucker } \\
\text { Olive-sided Flycatcher } \\
\text { Hammond' Flycatcher" } \\
\text { Plumbeous Vireo } \\
\text { Orange-crowned Warbler }\end{array}$ & $\begin{array}{l}\text { Northem Goshawk' } \\
\text { Sage Grouse } \\
\text { Sage Thrusher }\end{array}$ \\
\hline Rare & & Ovenbird & & $\begin{array}{l}\text { Peregrine Faloon }{ }^{1} \\
\text { Great Oray Owli } \\
\text { Boreal Owl } \\
\text { Lewis' Woodpeckeri } \\
\text { Black-backed Woodpecker }\end{array}$ \\
\hline
\end{tabular}


Table 4. Matrix of amphibian, reptile, and mammal species by various attributes, including seasonal use, association with riparian habitats, conservation status, home range size, risk factors over time, and vulnerability to bank stabilization activities. Code definitions are on the following page.

\begin{tabular}{|c|c|c|c|c|c|c|c|c|}
\hline Species & $\begin{array}{c}\text { Seasonal } \\
\text { use }\end{array}$ & $\begin{array}{l}\text { Assoc w/ } \\
\text { riparian }\end{array}$ & \multicolumn{2}{|c|}{$\begin{array}{l}\text { Natural Heritage } \\
\text { Program Rank }\end{array}$} & Home range size & Risk factors & Time scale & $\begin{array}{l}\text { Vulnerability } \\
\text { to bank } \\
\text { stabilization } \\
\text { activities }\end{array}$ \\
\hline \multicolumn{9}{|l|}{ Amphibians } \\
\hline $\begin{array}{l}\text { Tiger salamander (Ambystoma tigrinum) } \\
\text { Boreal (western) toad (Bufo boreas) } \\
\text { Western chorus frog (Pseudacris triseriala) } \\
\text { Spotted frog (Rana pretiosa) }\end{array}$ & $\begin{array}{l}d, b, f \\
d, b, f \\
d, b, f \\
d, b, f\end{array}$ & $\begin{array}{l}\text { oblig } \\
\text { oblig } \\
\text { oblig } \\
\text { oblig }\end{array}$ & $\begin{array}{l}\text { G5 } \\
\text { G4 } \\
\text { G5 } \\
\text { G4 }\end{array}$ & $\begin{array}{l}\text { S5 } \\
\text { S3 } \\
\text { S5 } \\
\text { S4 }\end{array}$ & $\begin{array}{l}\text { probably }<3 \mathrm{~km}^{2} \\
\text { average } 46,185 \mathrm{~m}^{2} \\
\text { unknown } \\
\text { unknown }\end{array}$ & $\begin{array}{l}S M, V_{1} \\
S M, V_{8} \\
S M, V_{2} \\
S M, V_{2}\end{array}$ & $\begin{array}{l}\text { years } \\
\text { years } \\
\text { years } \\
\text { years }\end{array}$ & $\begin{array}{l}\text { high } \\
\text { high } \\
\text { high } \\
\text { high }\end{array}$ \\
\hline \multicolumn{9}{|l|}{ Reptiles } \\
\hline $\begin{array}{l}\text { Sagebrush lizard (Sclemporus graciosus) } \\
\text { Rubber boa (Charina bottae) } \\
\text { Racer (Coluber constrictor) } \\
\text { Western ganter snake (Thamnophis elegans) } \\
\text { Western rattlesnake (Crolalus viridis) }\end{array}$ & $\begin{array}{l}f, p \\
d, b, f, p \\
d, b, f, p \\
d, b, f, p \\
f, p\end{array}$ & $\begin{array}{l}\text { limited } \\
\text { assoc } \\
\text { assoc } \\
\text { assoc } \\
\text { limited }\end{array}$ & $\begin{array}{l}\text { G5 } \\
\text { G5 } \\
\text { G5 } \\
\text { G5 } \\
\text { G5 }\end{array}$ & $\begin{array}{l}\text { S3 } \\
\text { S4 } \\
\text { S5 } \\
\text { S5 } \\
\text { S4 }\end{array}$ & $\begin{array}{l}\text { unknown } \\
\text { a few ha } \\
0.18-9.3 \mathrm{ha} \\
10-10,000 \mathrm{~m}^{2} \\
<1,600-5,640 \mathrm{~m}\end{array}$ & $\begin{array}{l}1 \\
S M, V_{2} \\
S M, V_{g} \\
S M, V_{2}\end{array}$ & $\begin{array}{l}\text { years } \\
\text { years } \\
\text { years } \\
\text { years }\end{array}$ & $\begin{array}{l}\text { medium } \\
\text { high } \\
\text { high } \\
\text { high } \\
\text { low }\end{array}$ \\
\hline \multicolumn{9}{|l|}{ Mammals } \\
\hline $\begin{array}{l}\text { Water shrew (Sorex palustris) } \\
\text { Preble's shrew (Sorex preblei) } \\
\text { Fringed myotis (Myotis thysanodes) } \\
\text { Townsend's big eared bat (Corynorhinus townsendii) } \\
\text { Grey wolf (Canis lupis) } \\
\text { Lynx (Lynx lynx) } \\
\text { Wolverine (Gulo gulo) } \\
\text { Grizzly bear (Ursus arclos) } \\
\text { Uinta chipmunk (Tamias umbrinus) }\end{array}$ & $\begin{array}{l}d, b, f \\
d, b, f \\
d, b, f, p \\
d, b, f, p \\
d, b, f, p \\
d, b, f, p \\
d, b, f, p \\
d, b, f, p \\
d, b, f, p\end{array}$ & $\begin{array}{l}\text { oblig } \\
\text { occas } \\
\text { occas } \\
\text { assoc } \\
\text { occas } \\
\text { occas } \\
\text { occas } \\
\text { assoc } \\
\text { occas }\end{array}$ & $\begin{array}{l}\text { G5 } \\
\text { G4 } \\
\text { G5 } \\
\text { G4 } \\
\text { G4 } \\
\text { G5 } \\
\text { GS/T4 } \\
\text { G4/T3 } \\
\text { G5 }\end{array}$ & $\begin{array}{l}\text { S5 } \\
\text { S3 } \\
\text { S3 } \\
\text { S2/S3 } \\
\text { S1 } \\
\text { S2 } \\
\text { S2 } \\
\text { S1/S2 } \\
\text { S3 }\end{array}$ & $\begin{array}{l}\text { unknown } \\
\text { unknown } \\
2-5 \mathrm{~km} \text { from day roosts } \\
1.0-4.2 \mathrm{~km} \text { range } \\
130-13,000 \mathrm{~km}^{2} \\
11-300 \mathrm{~km}^{2} \\
100-600 \mathrm{~km}^{2} \\
55-234 \mathrm{~km}^{2} \\
\text { ca } 1-6 \mathrm{ha}\end{array}$ & $\begin{array}{c}S M, V_{1} I \\
1 \\
1\end{array}$ & $\begin{array}{l}\text { years } \\
\text { years } \\
\text { years } \\
\text { years }\end{array}$ & $\begin{array}{l}\text { high } \\
\text { medium } \\
\text { low } \\
\text { low } \\
\text { low } \\
\text { low } \\
\text { low } \\
\text { low } \\
\text { medium }\end{array}$ \\
\hline
\end{tabular}

'See species accounts for more information. 


\section{Codes}

\section{Seasonal use}

d - denning, $b$ - breeding, $f$ - foraging, $p$ - passing through

\section{Association with riparian habitats}

Riparian obligate - occurs only in riparian habitats

Riparian associate - oflen found in riparian habitats, but regularly occurs elsewhere

Occasional use of riparian habitats - occurs in riparian habitats, but generally occurs in other habitats

Limited use of riparian habitats - occurrence in riparian habitats is rare

Natural Heritage Program Rank. The definitions for global (G) and state (S) ranks for conservation status are as follows:

1- Critically imperiled because of extreme rarity.

2 - Imperiled because of rarity or other factors demonstrably making it very vulnerable to extinction throughout its range.

3 - Either very rare and local throughout its range, or found locally (even abundantly at some of its locations) in a restricted range, or vulnerable to extinction throughout its range because of other factors; in the range of 21 to 100 occurrences.

4 - Apparently secure, though it may be quite rare in parts of its range, especially at the periphery.

5 - Demonstrably secure, though it may be quite rare in parts of its range, especially at the periphery.

Risk factors; vulnerability contingent upon modification of factors

F - decrease in fish populations

SM - stream habitat and morphology

$V$ - riparian vegetation ( $V_{g}=$ susceptible to changes in groundcover, $V_{a}=$ susceptible to loss of aquatic vegetation)

1 - susceptible to decline in insect populations

Time scale - period of time over which negative effects of bank stabilization would appear. Years - within months or a few years; decades - over a much longer period of time, a few to many decades.

\section{Vulnerability to bank stabilization activities}

High - Highly vulnerable or very likely at risk

Medium - Somewhat at risk

Low - Probably litule risk or no risk 
As such, we expect that stream bank stabilization activities would have minimal impact. Grizzly bears typically forage in low elevation riparian areas in spring, however, they are uncommon along the upper Yellowstone River. Although grey wolves are known to cross the valley (R. Hazlewood, personal communication), they probably do not occur regularly along the river. The lynx may be found along the river in winter, but probably only rarely. While wolverines may use the river as a water source, they are considered more forest carnivores and use of riparian areas is limited. The Uinta chipmunk is an occasional user of riparian habitats that would be affected by a decline in food resources, especially larval insects.

\section{Implications for Conservation}

This information can alert managers and landowners to the most serious effects of cumulative bank stabilization activities and guide additional research efforts. Hansen et al. (1992) propose an approach to maintaining biodiversity in the face of landscape changes with several clear steps. These steps are to: (1) set clear objectives, (2) associate target species with specific habitat configurations, (3) assess the potential viability of species, and (4) project future habitat patterns under alternative management prescriptions using simulation models. This document can assist in the second and third of these objectives.

\section{Acknowledgments}

Rob Hazlewood provided the inspiration for this document. The Technical Advisory Committee to the Yellowstone River Task Force provided the list of species of interest.

We thank Mike Bogan, Cindy Ramotnik, Gordon Rodda, Laura Ellison, and P. Stephen Corn for information on life history and distribution of herpetofauna and mammals. Michael L. Scott provided information on the linkage of fluvial geomorphology and riparian vegetation in northern Great Plains rivers. Rob Hazlewood and Michael Merigliano provided comments on earlier drafts of the document. Dora Medellin and Jennifer Shoemaker assisted with the publication of this document, and Dale Crawford provided the art work.

\section{Literature Cited}

Aderhold, M. 1996. Montana's endangered species, a status report. Montana Outdoors 27(28):8-13.

Adkisson, C. S. 1996. Red Crossbill (Loxia curvirostra). In The Birds of North America, No. 256, A. Poole and F. Gill, editors. The Birds of North America, Inc., Philadelphia, PA.

American Ornithologists' Union. 1998. Check-list of North American Birds. Seventh edition. American Ornithologists' Union, Washington, D.C.

Ammon, E. M. 1995. Lincoln's Sparrow (Melospiza lincolnii). In The Birds of North America, No. 191, A. Poole and F. Gill, editors. The Birds of North America, Inc., Philadelphia, PA.

Association for Biodiversity Information. 2000. NatureServe: An online encyclopedia of life. URL: http://www.natureserve.org/

Auble, G. T., and M. L. Scott. 1998. Fluvial disturbance patches and cottonwood recruitment along the upper Missouri River, Montana. Wetlands 18:546-556.

Banfield, A. W. F. 1974. The mammals of Canada. The University of Toronto Press, Ontario. $438 \mathrm{pp}$.

Beneski, J. T., Jr., and D. W. Stinson. 1987. Mammalian species, Sorex palustris. American Society of Mammalogists 296:1-6.

Blenden, M. D., M. J. Armbruster, T. S. Baskett, and A. H. Farmer. 1984. Evaluation of model assumptions: the relationship between plant biomass and arthropod abundance. Pages 11-14 in J. Verner, M. L. Morrison, and C. J. Ralph, editors. Wildlife 2000: Modeling habitat relationships of terrestrial vertebrates. University of Wisconsin Press, Madison.

Bogan, M. A., and P. M. Cryan. 2000. The bats of Wyoming. Pages 71-94 in J. R. Choate, editor. Reflections of a naturalist: Papers honoring Professor Eugene D. Fleharty. Fort Hays Studies, Special Issue 1. $241 \mathrm{pp}$.

Boggs, K., and T. Weaver. 1994. Changes in vegetation and nutrient pools during riparian succession. Wetlands 14:98-109.

Bradley, C. E., and D. G. Smith. 1986. Plains cottonwood recruitment and survival on a prairie meandering river floodplain, Milk River, southern Alberta and northern Montana. Canadian Journal of Botany 64:1433-1442.

Brainerd, S. 1989. Those small Montana wild cats. Montana Outdoors 20(6):21-37. 
Brinson, M. M., B. L. Swift, R. C. Plantico, and J. S. Barclay. 1981. Riparian ecosystems: their ecology and status. U.S. Fish Wildlife Service Biological Report 81. U.S. Government Printing Office, Washington, D.C.

Briskie, J. V. 1994. Least Flycatcher (Empidonax minimus). In The Birds of North America, No. 99, A. Poole and F. Gill, editors. The Birds of North America, Inc., Philadelphia, PA.

Brown, W. S. and W. S. Parker. 1976. Movement ecology of Coluber constrictor near communal hibernacula. Copeia 1978:225-242.

Bull, E. L., and J. R. Duncan. 1993. Great Gray Owl (Strix nebulosa). In The Birds of North America, No. 41, A. Poole and F. Gill, editors. The Birds of North America, Inc., Philadelphia, PA.

Carey, C., P. S. Corn, M. S. Jones, L. J. Livo, E. Muths, and C. W. Loeffler. In press. Environmental and life history factors that limit recovery in southern rocky mountain populations of boreal toads (Bufo boreas). In M. Lannoo, editor. Status and conversation of U.S. amphibians. University of California Press, Berkeley.

Chapman, J. A., and G. A. Feldhamer. 1982. Wild mammals of North America: Biology, management, and economics. The Johns Hopkins University Press, Baltimore, Md. 1147 pp.

Chilton, G., M. C. Baker, C. D. Barrentine, and M. A. Cunningham. 1995. White-crowned Sparrow (Zonotrichia leucophrys). In The Birds of North America, No. 183, A. Poole and F. Gill, editors. The Birds of North America, Inc., Philadelphia, PA.

Christian, K. A. 1976. Ontogeny of the food niche of Pseudacris triseriata. M.S. thesis, Colorado State University, Fort Collins.

Christian, K. A. 1982. Changes in the food niche during postmetamorphic ontogeny of the frog $P$ seudacris triseriata. Copeia 1982:73-80.

Christy, R. E., and S. D. West. 1993. Biology of bats in Douglas-fir forests. USDA Forest Service General Technical Report PNW-GTR-308, Pacific Northwest Research Station, Portland, Oreg. 28 pp.

Clark, T. W., and M. R. Stromberg. 1987. Mammals in Wyoming. University Press of Kansas, Lawrence.

Clark, T. W., A. H. Harvey, R. D. Dom, D. L. Günter, and C. Groves, editors. 1989. Rare, sensitive, and threatened species of the Greater Yellowstone Ecosystem. Northern Rockies Conservation Cooperative, Montana Natural Heritage Program, The Nature Conservancy, and Mountain West Environmental Services. Jackson, Wyo. 153 pp.
Cornely, J. E., L. N. Carraway, and B. J. Verts. 1992. Mammalian species, Sorex preblei. American Society of Mammalogists 416:1-3.

Dobbs, R. C., P. R. Martin, and T. E. Martin. 1998. Green-tailed Towhee (Pipilo chlorurus). In The Birds of North America, No. 309, A. Poole and F. Gill, editors. The Birds of North America, Inc., Philadelphia, PA.

Dobkin, D. S., A. C. Rich, and W. H. Pyle. 1998. Habitat and avifaunal recovery from livestock grazing in a riparian meadow system of the northwestern Great Basin. Conservation Biology 12:209-221.

Duellman, W. E. and L. Trueb. 1986. Biology of amphibians. The Johns Hopkins University Press, Baltimore, $\mathrm{Md}$.

Duvall, D., M. B. King, and K. J. Gutzwiller. 1985. Behavioral ecology and ethology of the prairie rattlesnake. National Geographic Research 1:80-111.

Eaton, S. W. 1995. Northern Waterthrush (Seiurus noveboracensis). In The Birds of North America, No. 182, A. Poole and F. Gill, editors. The Birds of North America, Inc., Philadelphia, PA.

Ehrlich, P. R., D. S. Dobkin, and D. Wheye. 1988. The Birder's Handbook. Simon and Schuster, New York, NY.

Ellis, J., C. Jones, D. Genter, J. Reichel, B. Spettigue, and D. Sullivan. 1996. P. D. Skaar's Montana bird distribution. Fifth edition, Montana Natural Heritage Program Special Publication Number 3. 129 pp.

Enderson, J. H., W. Heinrich, L. Kiff, and C. M. White. 1995. Population changes in North American peregrines. Transactions of the North American Fish and Wildlife Conference 60:142-161.

Evans, R. M., and F. L. Knopf. 1993. American White Pelican (Pelecanus erythrorhynchos). In The Birds of North America, No. 57, A. Poole and F. Gill, editors. The Birds of North America, Inc., Philadelphia, PA.

Faaborg, J., F. R. Thompson III, S. K. Robinson, T. M. Donovan, D. R. Whitehead, and J. D. Braun. 1998. Understanding fragmented Midwestern landscapes: The future. Pp. 193-208 in J. M. Marzluff, and R. Sallabanks, editors. Avian conservation: Research and management. Island Press, Washington, D.C.

Farr, D. 1988. The ecology of the gartersnakes Thamnophis sirtalis and T. elegans in southeastern British Columbia. M.S. thesis, University of Victoria, British Columbia.

Flath, D. L. 1975. The wolf. Montana Outdoors 6:4245. 
Flath, D. L. 1984. Vertebrate species of special interest or concern: Mammals, birds, reptiles, amphibians, and fishes. Wildlife Division, Montana Department of Fish, Wildlife and Parks, Helena.

Friedman, J. M., M. L. Scott, and G. T. Auble. 1997. Water management and cottonwood forest dynamics along prairie streams. Pages 49-71 in F. L. Knopf and F. Samson, editors. Ecology and conservation of Great Plains vertebrates. Springer-Verlag, New York, NY.

Genter, D. L. 1984. Life history notes: Crotalus viridis (prairie rattlesnake): Food. Herpetological Review 15:49-50.

Graves, B. M., and D. Duvall. 1993. Reproduction, rookery use, and thermoregulation in free-ranging, pregnant Crotalusv. viridis. Journal of Herpetology 27:3341.

Greene, E., V. R. Muehter, and W. Davison. 1996. Lazuli Bunting (Passerina amoena). In The Birds of North America, No. 232, A. Poole and F. Gill, editors. The Birds of North America, Inc., Philadelphia, PA.

Greenlaw, J. S. 1996. Spotted Towhee (Pipilo maculatus). In The Birds of North America, No. 309, A. Poole and F. Gill, editors. The Birds of North America, Inc., Philadelphia, PA.

Hahn, T. P. 1996. Cassin's Finch (Carpodacus cassinii). In The Birds of North America, No. 240, A. Poole and F. Gill, editors. The Birds of North America, Inc., Philadelphia, PA.

Hall, E. R. 1981. The Mammals of North America. John Wiley and Sons, New York, 2 volumes. $1271 \mathrm{pp}$.

Hamas, M. J. 1994. Belted Kingfisher (Ceryle alcyon). In The Birds of North America, No. 84, A. Poole and F. Gill, editors. The Birds of North America, Inc., Philadelphia, PA.

Hammerson, G. A. 1999. Amphibians and reptiles in Colorado. Second edition. University of Colorado Press, Boulder, and the Colorado Division of Wildlife.

Hansen, A. J., and D. L. Urban. 1992. Avian response to landscape pattern: The role of species' life histories. Landscape Ecology 7:163-180.

Hansen, P. L., K. Boggs, R. Pfister, and J. Joy. 1991. Classification and management of riparian-wetland sites in Montana. Montana Riparian Association, University of Montana, Missoula.

Hansen, A. J., S. L. Garman, B. Marks, and D. L. Urban. 1992. An approach for managing vertebrate diversity across multiple-use landscapes. Ecological Applications 3:481-496.

Hansen, A. J., J. J. Rotella, M. P. V. Kraska, and D. Brown. 1999. Dynamic habitat and population analysis: an approach to resolve the biodiversity manager's dilemma. Ecological Applications 9:14591476.

Hayward, G. D., and P. H. Hayward. 1993. Boreal Owl (Aegolius funereus). In The Birds of North America, No. 63, A. Poole and F. Gill, editors. The Birds of North America, Inc., Philadelphia, PA.

Hendricks, P., K. A. Jurist, D. L. Genter and J. D. Reichel. 1996. Bats of the Kootenai National Forest, Montana. Montana Natural Heritage Program, Helena. 99 pp.

Hill, G. E. 1995. Black-headed Grosbeak (Pheucticus melanocephalus). In The Birds of North America, No. 143, A. Poole and F. Gill, editors. The Birds of North America, Inc., Philadelphia, PA.

Hudon, J. 1999. Western Tanager (Piranga ludoviciana). In The Birds of North America, A. Poole and F. Gill, editors. The Birds of North America, Inc., Philadelphia, PA.

Humphrey, S. R, and T. H. Kunz. 1976. Ecology of a Pleistocene relict, the western big-eared bat (Plecotus townsendii), in the southern Great Plains. Journal of Mammalogy 57:470-494.

Hunter, W. C., M. F. Carter, D. N. Pashley, and K. Barker. 1993. The Partners In Flight prioritization scheme. Proceedings of the Symposium on Status and Management of Neotropical Migratory Birds, Estes Park, Colo. USDA Forest Service Rocky Mountain Range and Experiment Station General Technical Report RM-229.

Hutto, R. L. 1995. Composition of bird communities following stand-replacement fires in northern Rocky Mountain (U.S.A.) conifer forests. Conservation Biology 9:1041-1058.

Hutto, R. L., and J. S. Young. 1999. Habitat relationships of landbirds in the Northern Region, USDA Forest Service. General Technical Report RMRSGTS-32. USDA Forest Service, Rocky Mountain Research Station, Ogden, Utah. 72 pp.

Ingold, J. L., and G. E. Wallace. 1994. Ruby-crowned Kinglet (Regulus calendula). In The Birds of North America, A. Poole and F. Gill, editors. The Birds of North America, Inc., Philadelphia, PA.

Jones, C. R. S. Hoffmann, D. W. Rice, M. D. Engstrom, R. D. Bradley, D. J.Schmidly, C. A. Jones, and R.J. 
Baker. 1997. Revised checklist of North American Mammals north of Mexico. Museum of Texas Tech. University Occasional Papers Number 173, Lubbock. Johnsgard, P. A. 1986. Birds of the Rocky Mountains. Colorado Associated University Press, Boulder.

Jones, M. S., editor. 1999. Boreal toad research progress report. Colorado Division of Wildlife, Denver.

King, M. B., and D. Duvall. 1990. Prairie rattlesnake seasonal migrations: episodes of movement, vernal foraging, and sex differences. Animal Behavior 39:924-935.

Kingery, H. E. 1996. American Dipper (Cinclus mexicanus). In The Birds of North America, A. Poole and F. Gill, editors. The Birds of North America, Inc., Philadelphia, PA.

Klauber, L. M. 1997. Rattlesnakes. Volume 1. University of California Press, Berkeley.

Koch, E. D., and C. R. Peterson. 1995. Amphibians and reptiles of Yellowstone and Grand Teton National Parks. University of Utah Press, Salt Lake City. 188 pp.

Kunz, T. H, and R. A. Martin. 1982. Mammalian species, Plecotus townsendii. American Society of Mammalogists 175:1-6.

MacArthur, R. H., J. W. MacArthur, and J. Preer. 1962. On bird species diversity. II. Predictions of bird census from habitat measurements. American Naturalist 96:167-174.

Macartney, J. M., P. T. Gregory, and K. W. Larsen. 1988. A tabular source of data on movements and home ranges of snakes. Journal of Herpetology 22:61-73.

Mace, G. M., and N. J. Collar. 1995. Extinction risk assessment for birds through quantitative criteria. Ibis 137 (Supplement 1):S240-S246.

Mech, L. D. 1974. Mammalian species, Canis lupus. American Society of Mammalogists 37:1-6.

Mech, L. D. 1981. The Wolf: the Ecology and Behavior of an Endangered Species. University of Minnesota Press, Minneapolis. 384 pp.

Middleton, A. L. A. 1998. Chipping Sparrow (Spizella passerina). In The Birds of North America, No. 256, A. Poole and F. Gill, editors. The Birds of North America, Inc., Philadelphia, PA.

Millsap, B. A., J. A. Gore, D. E. Runde, and S. I. Cerulean. 1990. Setting priorities for the conservation of fish and wildlife species in Florida. Wildlife Monograph 111:1-57.

Millsap, B. A., P. L. Kennedy, M. A. Byrd, G. Court, J. H. Enderson, and R. N. Rosenfield. 1998. Review of the proposal to de-list the American peregrine falcon. Wildlife Society Bulletin 26:522-538.
Mitchell, C. D. 1994. Trumpeter Swan (Cygnus buccinator). In The Birds of North America, A. Poole and F. Gill, editors. The Birds of North America, Inc., Philadelphia, PA.

Montana Natural Resources Information System. 2000. URL: http://nris.state.mt.us and http:// nris.state.mt.us/mtnhp/index.html.

Montana Partners In Flight. 2000. Draft Bird Conservation Plan, Montana. URL: http://www.blm.gov/ wildlife/plan/pl_mt_10.pdf

Moskoff, W. 1995. Veery (Catharus fuscescens). In The Birds of North America, No. 142, A. Poole and F. Gill, editors. The Birds of North America, Inc., Philadelphia, PA.

Murphy, M. T. 1996. Eastern Kingbird (Tyrannus tyrannus). In The Birds of North America, A. Poole and F. Gill, editors. The Birds of North America, Inc., Philadelphia, PA.

National Geographic Society. 1987. Field guide to the Birds of North America. Second edition. National Geographic Society, Washington, D.C.

National Geographic Society. 1999. Field Guide to the Birds of North America. Third edition. National Geographic Society, Washington, D.C.

Nowak, R. M. 1991. Walker's mammals of the world. The Johns Hopkins University Press, Baltimore, Md.

O'Farrell, M. J., and E. H. Studier. 1980. Mammalian species, Myotis thysanodes. American Society of Mammalogists 137:1-5.

Oring, L. W., E. M. Gray, and J. M. Reed. 1997. Spotted Sandpiper (Actitis macularia). In The Birds of North America, No. 289, A. Poole and F. Gill, editors. The Birds of North America, Inc., Philadelphia, PA.

Pasitschniak-Arts, M. 1993. Mammalian species, Ursus arctos. American Society of Mammalogists 439:110.

Pasitschniak-Arts, M., and S. Lariviere. 1995. Mammalian species, Gulo gulo. American Society of Mammalogists 499:1-10.

Pierson, E. D., M. C. Wackenhut, J. S. Altenbach, P. Bradley, P. Call, D. L. Genter, C. E. Harris, B. L. Keller, B. Lengus, L. Lewis, B. Luce, K. W. Navo, J. M. Perkins, S. Smith, and L. Welch. 1999. Species conservation assessment and strategy for Townsend's big-eared bat (Coryhorhinus townsendii townsendii and Coryhorhinus townsendii pallescens). Idaho conservation effort. Idaho Department of Fish and Game, Boise. 63 pp.

Pitocchelli, J. 1995. MacGillivray's Warbler (Oporornis tolmiei). In The Birds of North America, No. 159, 
A. Poole and F. Gill, editors. The Birds of North America, Inc., Philadelphia, PA.

Place, C. B. 1992. Meet the nubber boa. Montana Outdoors 23(5): 35-37.

Redmond, R. L., M. M. Hart, J. C. Winne, W. A. Williams, P. C. Thornton, Z. Ma, C. M. Tobalske, M. M. Thornton, K. P. McLaughlin, T. P. Tady, F. B. Fisher, and S. W. Running. 1998. The Montana gap analysis Project: Final report. Montana Cooperative Wildlife Research Unit, University of Montana, Missoula. xiii + 136 pp. + appendices.

Reichel, J., and D. Flath. 1995. Identification of Montana's amphibians and reptiles. Montana Outdoors 26(3):15-34.

Reynolds, T. D. 1979. Response of reptile populations to different land management practices on the Idaho National Engineering Laboratory site. Great Basin Naturalist 39:255-262.

Rosen, P. C. 1991. Comparative ecology and life history of the racer Coluber constrictor in Michigan. Copeia 1991:20-26.

Rosenberg, K. V., J. D. Lowe, and A. A. Dhondt. 1999. Effects of forest fragmentation on breeding tanagers: A continental perspective. Conservation Biology 13:568-583.

Rossman, D. A., N. B. Ford, and R A. Seigel. 1996. The garter snakes: Evolution and ecology. University of Oklahoma Press, Norman.

Rotenberry, J. T., M. A. Patten, and K. L. Preston. 1999. Brewer's Sparrow (Spizella breweri). In The Birds of North America, No. 390, A. Poole and F. Gill, editors. The Birds of North America, Inc., Philadelphia, PA.

Saab, V. 1999. Importance of spatial scale to habitat use by breeding birds in riparian forests: A hierarchical analysis. Ecological Applications 9:135-151.

Sauer, J. R., J. E. Hines, I. Thomas, J. Fallon, and G. Gough. 2000. The North American Breeding Bird Survey, Results and Analysis 1966 - 1999. Version 98.1, USGS Patuxent Wildlife Research Center, Laurel, Md. URL: http://www.mbr.nbs.gov/bbs/bbs.html Scott, M. L., G. T. Auble, and J. M. Friedman. 1997. Flood dependency of cottonwood establishment along the Missouri River, Montana, USA. Ecological Applications 7:677-690.

Scott, M. L., J. M. Friedman, and G. T. Auble. 1996. Fluvial process and the establishment of bottomland trees. Geomorphology 14:327-339.
Scott, M. L., S. K. Skagen, and M. F. Merigliano. In review. Bird diversity and geomorphic change in riparian forests. Conservation Biology.

Secor, S. M. 1992. A preliminary analysis of the movement and home range size of the sidewinder Crotalus cerastes. Pages 389-393 in J. Campbell and E. Brodie, Jr., editors. Biology of the pitvipers. Selva, Tyler, Tex.

Sedgwick, J. A. 1993. Dusky Flycatcher (Empidonax oberholseri). In The Birds of North America, No. 78, A. Poole and F. Gill, editors. The Birds of North America, Inc., Philadelphia, PA.

Sedgwick, J. A. 1994. Hammond's Flycatcher (Empidonax hammondii). In The Birds of North America, No. 109, A. Poole and F. Gill, editors. The Birds of North America, Inc., Philadelphia, PA.

Servheen, C. 1983. Grizzly bear food habits, movements, and habitat selection in the Mission Mountains, Montana. Journal of Wildlife Management 47:1026-1035.

Sherry, T. W., and R. T. Holmes. 1997. American Redstart (Setophaga ruticilla). In The Birds of North America, No. 277, A. Poole and F. Gill, editors. The Birds of North America, Inc., Philadelphia, PA.

Skagen, S. K., C. P. Melcher, W. H. Howe, and F. L. Knopf. 1998. Comparative use of riparian corridors and oases by migrating birds in southeast Arizona. Conservation Biology 12:896-909.

Smith, D. 1980. River ice processes: Thresholds and geomorphic effects in northern and mountain rivers. Pages 323-343 in D. R. Coats and J. D. Vitek, editors. Thresholds in geomorphology. Allen and Unwin, Boston, Mass.

Sogge, M. K., W. M. Gilbert, and C. Van Riper, III. 1994. Orange-crowned Warbler (Vermivora celata). In The Birds of North America, No. 101, A. Poole and F. Gill, editors. The Birds of North America, Inc., Philadelphia, PA.

Squires, J. R., and S. H. Anderson. 1997. Changes in Trumpeter Swan (Cygnus buccinator) activities from winter to spring in the Greater Yellowstone Area. American Midland Naturalist 138:208-214.

Squires, J. R., and R. T. Reynolds. 1997. Northern Goshawk (Accipiter gentilis). In The Birds of North America, No. 298, A. Poole and F. Gill, editors. The Birds of North America, Inc., Philadelphia, PA.

Stebbins, R. C. 1985. A field guide to western reptiles and amphibians. Houghton Mifflin Company, Boston, Mass. 
Streubel, D. 1989. Small mammals of the Yellowstone ecosystem. Roberts Rinehart, Inc. Publishers, Boulder, Colo.

Tewksbury, J. J., S. J. Hejl, and T. E. Martin. 1998. Breeding productivity does not decline with increasing fragmentation in a western landscape. Ecology 79:2890-2903.

Thomas, D. W., and S. D. West. 1991. Forest age associations of bats in the Washington Cascades and Oregon Coast Ranges. Pages 295-303 in L. F. Ruggiero, K. B. Aubrey, A. B. Carey, and M. H. Huff, editors. Wildlife and vegetation of unmanaged Douglas-fir forests. U.S. Department of Agriculture Forest Service Pacific Northwest Research Station General Technical Report PNW-285, Portland.

Thompson, L. S. 1982. Distribution of Montana's amphibians, reptiles and mammals, preliminary mapping by latilong. Montana Audubon Council, Helena.

Tinkle, D. W., A. E. Dunham, and J. D. Congdon. 1993. Life history and demographic variation in the lizard Sceloporus graciosus: A long-term study. Ecology 74:2413-2429.

Tobalske, B. W. 1997. Lewis' Woodpecker (Melanerpes lewis). In The Birds of North America, No. 284, A. Poole and F. Gill, editors. The Birds of North America, Inc., Philadelphia, PA.

Tumlison, R. 1987. Mammalian species, Felis lynx. American Society of Mammalogists 269:1-8.
USGS Patuxent Wildlife Research Center. 2000. North American Breeding Bird Survey Internet data set, 21 November 2000. URL: http://www.mp2pwrc.usgs.gov/ bbs/retrieval/

Van Horn, M. A., and T. Donovan. 1994. Ovenbird (Seiurus aurocapillus). In The Birds of North America, No. 88, A. Poole and F. Gill, editors. The Birds of North America, Inc., Philadelphia, PA.

Waller, J. S., and R. D. Mace. 1997. Grizzly bear habitat selection in the Swan Mountains, Montana. Journal of Wildlife Management 61:1032-1039.

White, D., P. G. Minotti, M J. Barcak, J. C. Sifneos, K. E. Freemark, M. V. Santelmann, C. F. Steinitx, A. R. Kiester, and E. M. Preston. 1997. Assessing risks to biodiversity from future landscape change. Conservation Biology 11:349-360.

Willson, M. F. 1974. Avian community organization and habitat structure. Ecology 55:1017-1029.

Wilson, D. E., and S. Ruff, editors. 1999. The Smithsonian Book of North American Mammals. Smithsonian Institution Press. Washington, D.C.

Witmer, M. C., D. J. Mountjoy, and L. Elliot. 1997. Cedar Waxwing (Bombycilla cedrorum). In The Birds of North America, No. 309, A. Poole and F. Gill, editors. The Birds of North America, Inc., Philadelphia, PA.

Wyoming Bioinformation Node's Species Atlas. 1999. URL: http://www.sdvc.uwyo.edu/wbn/atlas/ 


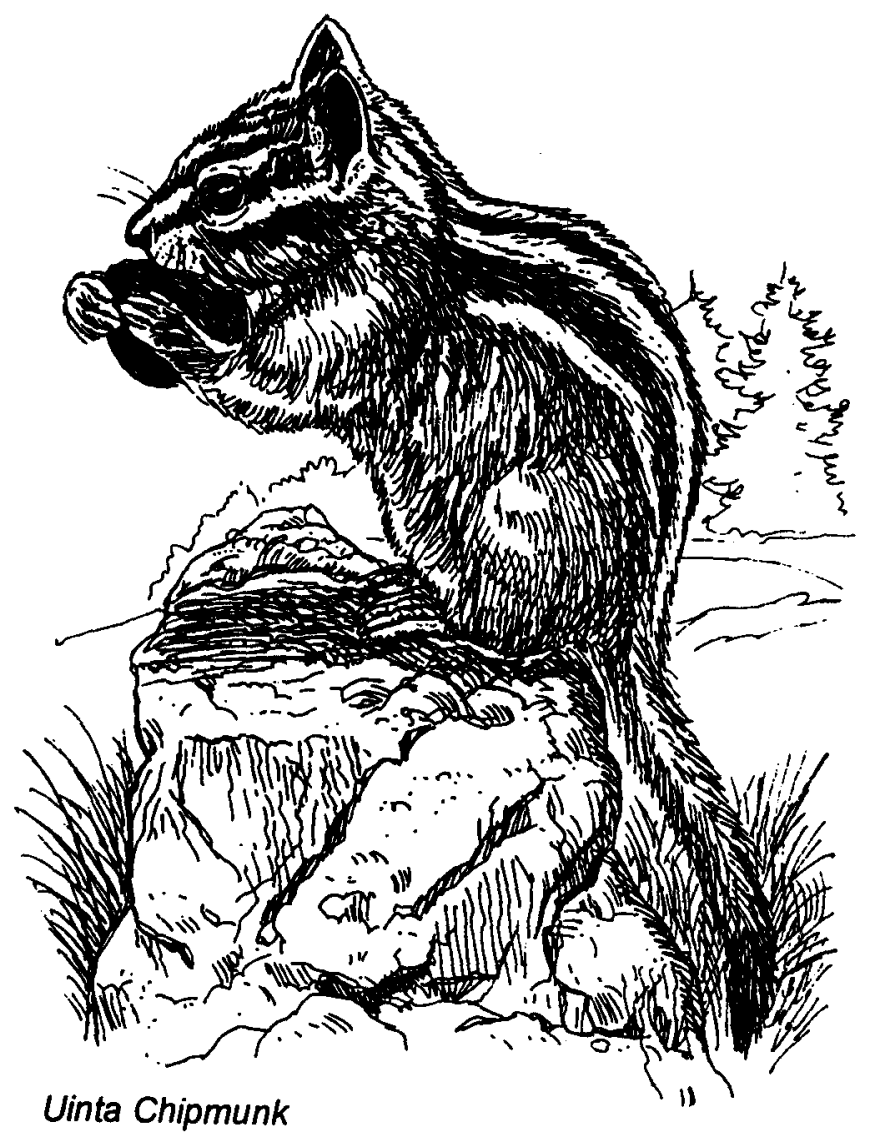


Appendix 1. Brief species accounts, including occurrence, abundance, and life history information for 69 bird species, 4 amphibians, 5 reptiles, and 9 mammals of the upper Yellowstone River, Montana.

\section{Birds}

\section{American White Pelican (Pelecanus erythrorhynchos)}

Occurrence: Migrates through Livingston latilong (Montana migration 18 April - 27 May and 15 August 18 October); there are transient/migrant records for QLL A, B, and C. Migrates through Bozeman latilong. Summer resident in Yellowstone latilong; breeding confirmed. Migrates through White Sulphur Springs latilong. Summer resident in Columbus latilong; indirect evidence of breeding. Montana and Wyoming egg records are from 17 May to 10 July (Johnsgard 1986:64, Ellis et al. 1996:15).

\section{Abundance: Common}

Diet: Fish; mainly "rough" fish of low economic value. Small schooling fish ( $<1.5$ bill length) predominate, but also takes larger sluggish bottom feeders, salamanders, and crayfish. Occurrence of regurgitated fish hooks and lures in colonies suggest they also take game fish injured or slowed by anglers (Evans and Knopf 1993).

Key Habitat Associations: Riparian associate. Freshwater obligate.

Foraging: Broad habitat preferences include shallow water $(0.3$ to $2.5 \mathrm{~m})$ of inland rivers, marshes, lakes, and reservoirs with shorelines ranging from mud/sand to gravel/rock, and with waters ranging from oligotrophic to eutrophic, muddy to clear. Some habitats are inherently unstable due to flooding and drying cycles (Evans and Knopf 1993). Most importantly, there must be large fish populations that can be reached by surface feeding (Johnsgard 1986); within $1 \mathrm{~m}$ of surface. Colonies may be located $80 \mathrm{~km}$ (50 miles) or more from the nearest food source, and pelicans may travel over $600 \mathrm{~km}$ (375 miles) round-trip to forage (Clark et al. 1989:55). Primary vegetation cover types in Wyoming are forest-dominated riparian, shrub-dominated riparian, and unclassified riparian (Wyoming Bioinformation Node's Species Atlas 1999).

Breeding: Primarily breeds on isolated islands in freshwater lakes. Molly Islands of Yellowstone Lake are a major western breeding area supporting about 180 nests/year (Johnsgard 1986, Evans and Knopf 1993); 401 nests recorded in 1988 (Clark et al. 1989:56). Nesting in shrub-dominated riparian area was also documented at Pathfinder Reservoir in Wyoming (Wyoming Bioinformation Node's Species Atlas 1999).

Elevation: 900-2,550 m (Wyoming Bioinformation Node's Species Atlas 1999).

Comments: Designated as a species of interest by the Technical Advisory Committee to the Upper Yellowstone River Task Force. Montana populations have been declining since early 1960 s, down from 10,000 breeders (Johnsgard 1986:64). Breeding colonies are highly sensitive to human disturbance and should not be approached within at least $0.4 \mathrm{~km}(0.25$ mile), especially in the early to middle stages of breeding which extend into late July (Clark et al. 1989:56). Altered fish populations would affect this species. 


\section{Trumpeter Swan (Cygnus buccinator)}

Occurrence: Migrates through Livingston latilong. Indirect evidence of breeding has been recorded for QLL $A$ and $\mathbf{C}$; there is a transient/migrant record for D. Summer resident in Columbus latilong; breeding confirmed. Year-round resident in Bozeman and Yellowstone latilongs; breeding confirmed. Migrates through White Sulphur Springs latilong. Typically, egg laying begins in late May, hatching in late June, and fledging in late September. Overwinters in Livingston latilong (Johnsgard 1986:77, Ellis et al. 1996:19).

Abundance: Common

Diet: Broad diet, consisting primarily of leaves, stems, roots, and tubers of submerged, floating, and emergent plants; secondarily, insects and crustaceans; rarely, vertebrates such as Coho salmon carcasses, fry, eggs, and small Rainbow trout (Mitchell 1994).

Key Habitat Associations: Riparian associate, freshwater obligate.

Foraging: Feeds in freshwater habitats, such as streams, rivers, ponds, lakes, and reservoirs. Food taken directly from water surface, water column, or substrate (if visible) (Mitchell 1994). Primary vegetation cover types in Wyoming are forest-dominated riparian and shrub-dominated riparian (Wyoming Bioinformation Node's Species Atlas 1999).

Breeding: Breeds occasionally on rivers but mostly on ponds, lakes, and marshes. Basic nesting habitat needs include room for take-off (approximately $100 \mathrm{~m}$ ), accessible forage, shallow stable levels of unpolluted freshwater, emergent vegetation, muskrat island or other structure for nest site, and low human disturbance. Prefers highly irregular shoreline, water depth of less than $1.2 \mathrm{~m}$, abundant and diverse communities of aquatic plants, early ice-off, and availability of many nest sites (Mitchell 1994). In the Rocky Mountains, usually limited to large ponds (over 30 acres) with considerable aquatic vegetation and seclusion from humans. Beaver ponds are sometimes used, and nests are sometimes built on beaver lodges (Johnsgard 1986:77).

Elevation: 900-2,400 m (Wyoming Bioinformation Node's Species Atlas 1999).

Comments: Designated as a species of interest by the Technical Advisory Committee to the Upper Yellowstone River Task Force. Priority I species designation (highest priority, recommendation of conservation action) by Montana Partners In Flight (2000). Historically, trumpeters nested across most of North America. By 1920, the species was nearly extinct due to the commercial swanskin trade, sport hunting, and habitat destruction. The Greater Yellowstone Ecosystem supported one of the few surviving populations and now supports virtually all wintering trumpeters of the Rocky Mountains (Clark et al. 1989:59-60); wintering populations have increased from 700 in 1974 to 2,200 in 1992 (Squires and Anderson 1997).

\section{Harlequin Duck (Histrionicus histrionicus)}

Occurrence: Summer resident in Livingston latilong; breeding confirmed. Indirect evidence of breeding has been recorded for QLL C and direct evidence for D. Summer resident in Yellowstone latilong; breeding confirmed. Summer resident in Bozeman, White Sulphur Springs, and Columbus latilongs; indirect evidence of breeding. There are Montana records of breeding in June; ducklings have been seen in July and August (Johnsgard 1986:98, Ellis et al. 1996:25).

Abundance: Uncommon 
Diet: Primarily aquatic invertebrates, such as crayfish and snails; also crustaceans, mollusks, and aquatic insects; rarely fish. Forages by walking on bottom of swift streams, searching among rocks (Ehrlich et al. 1988:88); stoneflies, mayflies, caddisflies, and dipterans; occasionally takes filamentous algae and sculpins (Clark et al. 1989:61).

Key Habitat Associations: Riparian obligate.

Foraging: Associated with clear, rapidly flowing streams where aquatic insects are abundant. Often found where dippers occur (Johnsgard 1986:98). Generally, streams are $10 \mathrm{~m}$ or wider with boulder substrate and mature to old growth overstory. Stream areas with grass or forb banks are used less frequently. Primary vegetation cover types in Wyoming are unclassified riparian, shrub-dominated riparian, and open water (Wyoming Bioinformation Node's Species Atlas 1999). Occurs in mid- to late seral stage coniferous riparian forest (Montana Partners In Flight 2000).

Breeding: Nest is usually $18-27 \mathrm{~m}$ from water, under a shrub. Occasionally, nests are in rock crevices among boulders or in tree cavities (Ehrlich et al. 1988:88). Nesting habitat features include very low gradient stream sections with dense shrubs lining the banks, braided channels, swift currents, and water rich in aquatic insect fauna; turbulent stream sections are used for security and foraging (Clark et al. 1989:61).

Elevation: 1,800-3,000 m (Wyoming Bioinformation Node's Species Atlas 1999).

Comments: Designated as a species of interest by the Technical Advisory Committee to the Upper Yellowstone River Task Force. Priority I species designation (highest priority, recommendation of conservation action) by Montana Partners in Flight (2000). Study site is at eastern edge of western breeding range (National Geographic Society 1999:90). Species is difficult to spot. Presence indicates high water quality (Johnsgard 1986:98).

\section{Bald Eagle (Haliaeetus leucocephalus)}

Occurrence: Year-round resident in Livingston latilong; breeding confirmed. Direct evidence of breeding has been recorded for QLL B and C. Year-round resident in Bozeman, Yellowstone, and Columbus latilongs; breeding confirmed. Winters and migrates through White Sulphur Springs latilong. Nesting records for Wyoming: hatching occurs near 1 May; fledging occurs near 10 July (Johnsgard 1986:112, Ellis et al. 1996:29).

\section{Abundance: Uncommon}

Diet: Fish, such as squawfish. Scavenges dying salmon (Johnsgard 1986:112); small mammals (especially rabbits), waterfowl, and carrion. Pirates food from other species and occasionally from conspecifics (Ehrlich et al. 1988:220). In the Greater Yellowstone area, adults forage primarily during early morning and late evening; immatures forage throughout the day (Clark et al. 1989:66).

Key Habitat Associations: Riparian associate.

Foraging: Broad habitat preferences include riparian, shrub-steppe, open grassland, coniferous and mixed forests. During breeding season, uses riparian and lacustrine habitats of coniferous and mixed forests (lodgepole pine, Douglas fir, spruce-fir, cottonwood). Forages in open habitats during winter (Wyoming Bioinformation Node's Species Atlas 1999).

Breeding: Nest is usually within 0.9 miles of shore, within forest corridor (Wyoming Bioinformation Node's Species Atlas 1999). Nests are often in fork of tall tree. Nests are used repeatedly, known to be used more than 35 years (Ehrlich et al. 1988:220). Nest is usually in a taller tree of a large stand. 
Density of eagle pairs is higher along river sections that are more braided and sinuous (Clark et al. 1989:66).

Elevation: 900-3,000 m (Wyoming Bioinformation Node's Species Atlas 1999).

Comments: Designated as a species of interest by the Technical Advisory Committee to the Upper Yellowstone River Task Force. Priority II species designation (second highest priority, recommendation of monitoring and/or conservation action) by Montana Partners in Flight (2000). Historically, Bald Eagles bred throughout North America. In the 1960s, populations shrank due primarily to effects of DDT. Since the 1973 banning of DDT use, populations have rebounded (Clark et al. 1989:65).

\section{Northern Goshawk (Accipiter gentilis)}

Occurrence: Year-round resident in Livingston latilong; breeding confirmed. There are transient/migrant records for QLL A, C, and D. Year-round resident in Bozeman, Yellowstone, and White Sulphur Springs latilongs; breeding confirmed. Migrates through Columbus latilong. Wyoming egg records are from 10 May to 17 June; nestlings reported from 17 June onwards (Johnsgard 1986:116, Ellis et al. 1996:30).

\section{Abundance: Uncommon}

Diet: Ground and tree squirrels, rabbits and hares, large passerines, woodpeckers, game birds, and corvids; occasionally reptiles and insects. Opportunist; kills a wide diversity of prey, depending on region, season, vulnerability, and availability (Squires and Reynolds 1997).

Key Habitat Associations: Limited use of riparian habitats.

Foraging: Forest-associate. Forest types range from oldest stands of timber (greater than $20.6 \mathrm{~cm}$ diameter at breast height) with no understory in breeding season, to low woodlands, riparian woods, and sage areas in non-breeding season. Associated strongly with Douglas fir, lodgepole pine, and aspen, but also uses fir-whitebark pine, spruce-fir, riparian, and juniper woodlands (Wyoming Bioinformation Node's Species Atlas 1999). Wintering habitats possibly determined by prey abundance, not woodland habitat; will hunt in riparian areas (Squires and Reynolds 1997). Foraging microhabitat guild is terrestrial generalist (Skagen et al. 1998).

Breeding: Typically nests in mature to old-growth forests of mostly large trees, with closed canopy and slight ground cover, near bottom of moderate hill slopes; but habitat characteristics vary across range; free water (e.g., rivers) is often near nests but not required (Squires and Reynolds 1997).

Elevation: 900-3,750 m (Wyoming Bioinformation Node's Species Atlas 1999).

Comments: Designated as a species of interest by the Technical Advisory Committee to the Upper Yellowstone River Task Force. Priority II species designation (second highest priority, recommendation of monitoring and/or conservation action) by Montana Partners In Flight (2000).

\section{American Kestrel (Falco sparverius)}

Occurrence: Summer resident in Livingston latilong; breeding confirmed: direct evidence of breeding has been recorded for QLL A, B, and C; there is a transient/migrant record for D. Year-round resident in Bozeman and White Sulphur Springs latilongs; breeding confirmed. Summer resident in Yellowstone latilong; breeding confirmed. Summer resident in Columbus latilong; indirect evidence of breeding. Occurs in Montana from March to November, overwintering in mild winters. Overwintering is suspected in 
Livingston latilong. In Montana, fledging occurs in July and August (Johnsgard 1986:124, Ellis et al. 1996:32).

\section{Abundance: Common}

Diet: Primarily insects, also small vertebrates and small mammals; occasionally birds (Ehrlich et al. 1988:244).

Key Habitat Associations: Occasional use of riparian habitats.

Foraging: Associated with open-country habitats, including agricultural areas, grasslands, sagebrush, and desert scrub. Avoids forests but sometimes forages in mountain meadows (Johnsgard 1986:124). In Wyoming, found in grasslands and shrublands interspersed with woodland (Wyoming Bioinformation Node's Species Atlas 1999). Associated patch and landscape-level features (for southeastern Idaho) are open canopies and subcanopies, herbaceous ground cover, bare ground, natural (non-agricultural) landscapes, and areas in which cottonwood patches are near each other (Saab 1999). Foraging microhabitat guild is terrestrial generalist (Skagen et al. 1998).

Breeding: Nest is typically in a tree cavity and occasionally on a cliff (Ehrlich et al. 1988:244).

Elevation: 900-2,850 m (Wyoming Bioinformation Node's Species Atlas 1999).

\section{Peregrine Falcon (Falco peregrinus)}

Occurrence: Year-round resident in Livingston latilong; breeding confirmed. There is a transient/migrant record for QLL A; direct evidence of breeding has been recorded for B, and indirect evidence of breeding has been recorded for C. Year-round resident in Bozeman and Yellowstone latilongs; breeding confirmed. Indirect evidence of breeding in White Sulphur Springs latilong. Migrates through Columbus latilong. Nestlings have been recorded in Montana from 10 July to 17 July (Johnsgard 1986:126, Ellis et al. 1996:33).

\section{Abundance: Rare}

Diet: Birds, especially doves and pigeons, shorebirds, waterfowl, and passerines (Ehrlich et al. 1988:248). A 16-km (10-mile) hunting radius is common (Clark et al. 1989:68).

Key Habitat Associations: Limited use of riparian habitats.

Foraging: Occurs typically in wooded habitats with cliffs, but non-breeders occur over a wide habitat range: mountain meadows, grasslands, marshes, riparian. Other habitats are ponds, grain croplands, pastures, gorges, basin-exposed rock, and desert shrubs (Wyoming Bioinformation Node's Species Atlas 1999).

Breeding: Nests are found on dominant cliffs at heights greater than $60 \mathrm{~m}$. Also uses bridges and buildings (Wyoming Bioinformation Node's Species Atlas 1999). Cliff sites are used traditionally for many years (Ehrlich et al. 1988:248).

Elevation: 900-2,700 m (Wyoming Bioinformation Node's Species Atlas 1999).

Comments: Designated as a species of interest by the Technical Advisory Committee to the Upper Yellowstone River Task Force. Priority II species designation (second highest priority, recommendation of monitoring and/or conservation action) by Montana Partners In Flight (2000). Serious population decline since the 1940s as a result of eggshell thinning from pesticides and PCB poisoning (Ehrlich et al. 1988:248). Although still absent from most of its historic breeding range in the mid-1980s (Johnsgard 1986:126), the species has made a remarkable recovery (Enderson et al. 1995, Millsap et al. 1998). In the Greater 
Yellowstone Ecosystem in 1989, 19 pairs were defending territories, and 22 young were fledged (Clark et al. 1989:69).

\section{Ruffed Grouse (Bonasa umbellus)}

Occurrence: Year-round resident in Livingston latilong; breeding confirmed: direct evidence of breeding has been recorded for QLL A and C; there is a transient/migrant record for D. Year-round resident in Bozeman, Yellowstone, White Sulphur Springs, and Columbus latilongs; breeding confirmed. In Wyoming, hatching occurs from mid-June to mid-July (Johnsgard 1986:137, Ellis et al. 1996:35).

\section{Abundance: Uncommon}

Diet: Omnivorous. Approximately $80 \%$ of diet is buds, leaves, flowers, seeds, and fruits; $20 \%$ insects, spiders, snails, and small vertebrates (Ehrlich et al. 1988:250).

Key Habitat Associations: Riparian associate in the West (Hutto and Young 1999).

Foraging: Highly associated with aspen woodlands, the buds and catkins of which provide a major food source. Also occurs up to the spruce-fir zone of coniferous forests (Johnsgard 1986:137). In Wyoming, found in middle-aged to younger stands of aspen, willow, cottonwood, mountain maple, and chokecherry trees, bordered by coniferous forests characteristic of western Wyoming (Wyoming Bioinformation Node's Species Atlas 1999).

Breeding: Nest is often concealed at base of tree, under branches of fallen tree, or next to $\log$ (Ehrlich et al. 1988:250).

Elevation: 900-3,150 m (Wyoming Bioinformation Node's Species Atlas 1999).

Comments: Priority II species designation (second highest priority, recommendation of monitoring and/or conservation action) by Montana Partners In Flight (2000). At high risk of extinction in the Greater Yellowstone Ecosystem (Hansen et al. 1999).

\section{Sage Grouse (Centrocercus urophasianus)}

Occurrence: Year-round resident in Livingston latilong; breeding confirmed prior to 1991 . Year-round resident in Yellowstone and White Sulphur Springs latilongs; breeding confirmed prior to 1991. Summer resident in Bozeman and Columbus latilongs; breeding confirmed prior to 1991. Wyoming egg records are from 18 April to 27 July (Johnsgard 1986:138, Ellis et al. 1996:35).

Abundance: Uncommon

Diet: Primarily plant greens, including flowers and buds from forbs; secondarily, insects. In autumn and winter, almost exclusively sagebrush leaves (Ehrlich et al. 1988:258).

Key Habitat Associations: Limited use of riparian habitats.

Foraging: Closely associated with sagebrush in a variety of semi-arid areas, including bitterbrushsagebrush steppe, basin-prairie and mountain-foothills shrubland, wet-moist meadows, alfalfa, irrigated native meadows, dry-land crops, desert shrub, and vegetated dunes. In central Montana, open areas were used for feeding and dense sagebrush for roosting. In Colorado, percent shrub cover is 
between 10 and $50 \%$ and average height of shrubs is between 10 and $40 \mathrm{~cm}$. Primary vegetation cover type in Wyoming is Wyoming big sagebrush (Wyoming Bioinformation Node's Species Atlas 1999). Breeding: Nest is a shallow depression slightly lined with grass and sage leaves, concealed under sagebrush (Ehrlich et al. 1988:258).

Elevation: 900-2,550 m (Wyoming Bioinformation Node's Species Atlas 1999).

Comments: Priority I species designation (highest priority, recommendation of conservation action) by Montana Partners In Flight (2000). Extent of habitat is slowly decreasing as sagebrush areas are cleared for irrigated cultivation. Wyoming has the nation's largest population (Johnsgard 1986:138).

\section{Spotted Sandpiper (Actitis macularia)}

Occurrence: Summer resident in Livingston latilong; breeding confirmed. Direct evidence of breeding has been recorded for QLL A, C, and D. Summer resident in Bozeman, Yellowstone, White Sulphur Springs, and Columbus latilongs; breeding confirmed. Occurs in Wyoming from 26 April to 5 October. Wyoming egg records are from 23 May to 7 August (Johnsgard 1986:161, Ellis et al. 1996:42).

Abundance: Common

Diet: Flying insects (captured from air and gleaned from water's surface), secondarily worms, fish, crustaceans, mollusks, carrion (Ehrlich et al. 1988:130).

Key Habitat Associations: Riparian obligate.

Foraging: Broad habitat preferences (within $200 \mathrm{~m}$ of water) include shoreline, sagebrush, grassland, and forest; sandy or firm substrate is preferred (Oring et al. 1997). Rocky shorelines are suitable, from lowland to alpine meadows, with water shallow and open (Wyoming Bioinformation Node's Species Atlas 1999). Water is usually shaded and may be rapidly flowing (Johnsgard 1986:161). Primary vegetation cover types in Wyoming are forest-dominated and shrub-dominated riparian (Wyoming Bioinformation Node's Species Atlas 1999). Foraging microhabitat guild is shoreline gleaner and prober (Skagen et al. 1998).

Breeding: Nest is located within $300 \mathrm{~m}$ (normally within $100 \mathrm{~m}$ ) of water's edge, normally under or next to herbaceous vegetation, which provides some shade. When predators are abundant, nest may be in forest or other dense vegetation. Broad strips of vegetation are preferred (Oring et al. 1997).

Elevation: 900-3,450 m (Wyoming Bioinformation Node's Species Atlas 1999).

Comments: The generalist nature of food and habitat selection possibly lowers susceptibility to disturbances on water's edge.

\section{Mourning Dove (Zenaida macroura)}

Occurrence: Year-round resident in Livingston latilong; breeding confirmed prior to 1991: indirect evidence of breeding has been recorded for QLL A; there is a transient/migrant record for C. Year-round resident in Bozeman latilong; breeding confirmed prior to 1991. Summer resident in Yellowstone, White Sulphur Springs, and Columbus latilongs; breeding confirmed prior to 1991. Occurs in Montana from mid-April to October. Montana egg records are from early June to 11 September (Johnsgard 1986:199, Ellis et al. 1996:56). 


\section{Abundance: Abundant}

Diet: Seeds (>99\%), including waste grain from agricultural fields; young are fed crop milk for first 3 days (Ehrlich et al. 1988:278).

Key Habitat Associations: Occasional use of riparian habitats.

Foraging: Occurs in a wide variety of habitats, including riparian woodlands, cultivated areas, grasslands, sagebrush, woodlands, aspen groves, open coniferous forest, and urban areas (Johnsgard 1986:199). In Wyoming, found in all habitats below $2,590 \mathrm{~m}$, both open woods and open country. In Colorado, associated with whitebark pine, Gambel oak, and cottonwood-willow (Wyoming Bioinformation Node's Species Atlas 1999). Associated patch and landscape-level features (for southeastern Idaho) are herbaceous ground cover, bare ground, and agricultural landscapes (Saab 1999). Foraging microhabitat guild is gleaner in forb layer, ground, and litter (Skagen et al. 1998).

Breeding: Nest is in fork of horizontal tree branch, on ground, on deserted nest of other species, or anyplace providing support; nest is flimsy (Ehrlich et al. 1988:278).

Elevation: 900-2,550 m (Wyoming Bioinformation Node's Species Atlas 1999).

\section{Black-billed Cuckoo (Coccyzus erythropthalmus)}

Occurrence: Summer resident in Livingston latilong; indirect evidence of breeding prior to 1991 . Summer resident in Bozeman latilong; breeding confirmed. Vagrant in Yellowstone latilong. Summer resident in Columbus latilong; indirect evidence of breeding. Occurs in Montana from late May to early October and nests in June (Johnsgard 1986:200, Ellis et al.1996:57).

\section{Abundance: Uncommon}

Diet: Insects, especially caterpillars, also mollusks, fish, small vertebrates, bird eggs, fruits, and berries (Ehrlich et al. 1988:286).

Key Habitat Associations: Riparian associate.

Foraging: Prefers dense cover during breeding season, in deciduous and mixed forests, open woodland (especially cottonwood riparian), and urban areas. Prefers forests but uses wooded edges, willow thickets, hedges, windrows, orchards, shrubs grown over by vines, and human settlements. Pure conifer stands are questionable habitats (Wyoming Bioinformation Node's Species Atlas 1999).

Breeding: Nest is typically 0.8 to $2 \mathrm{~m}$ above ground in deciduous tree or shrub, located horizontally against trunk. Nests may also be on logs, in vine tangles, and on ground (Ehrlich et al. 1988:286). Elevation: 800-2,400 m (Wyoming Bioinformation Node's Species Atlas 1999).

Comments: Designated as a species of interest by the Technical Advisory Committee to the Upper Yellowstone River Task Force. Priority II species designation (second highest priority, recommendation of monitoring and/or conservation action) by Montana Partners In Flight (2000). Study site is on western edge of range (National Geographic Society 1999:244). One known breeding area near study site (Johnsgard 1986:200).

\section{Great Gray Owl (Strix nebulosa)}

Occurrence: Summer resident in Livingston latilong; indirect evidence of breeding has been recorded for QLL A; there is a transient/migrant record for D; direct evidence of breeding was recorded for the latilong 
prior to 1991. Year-round resident in Bozeman and Yellowstone latilongs; breeding confirmed prior to 1991. Indirect evidence of breeding in White Sulphur Springs latilong prior to 1991. Transient in Columbus latilong (Johnsgard 1986:210, Ellis et al. 1996:60).

\section{Abundance: Rare}

Diet: Primarily voles; also shrews, moles, mice, pocket gophers, squirrels, lemmings, chipmunks, weasels, and hares. Secondarily birds: ducks, hawks, grouse, jays, robins (Ehrlich et al. 1988:294, Bull and Duncan 1993).

Key Habitat Associations: Limited use of riparian habitats.

Foraging: Forest-associate. Forages along the edges of meadows, clearcuts, and in open forests (Clark et al. 1989:82). Most sightings in Idaho and Wyoming (90\%) were in zone of lodgepole pine, Douglas fir, aspen (Bull and Duncan 1993). In Wyoming, associated with Douglas fir, spruce-fir, lodgepole pine, other conifers, aspen, subalpine meadows, and mountain-foothills grasslands near swamps and clearings. Prefers mature trees. Leaning trees and snags are important for juveniles (Wyoming Bioinformation Node's Species Atlas 1999).

Breeding: In southern range, breeds in deciduous or coniferous forests up to $2,800 \mathrm{~m}$ elevation. Nests most frequently in old raptor nests. Nests also in snags, mistletoe brooms, and human-made platforms. Nesting habitat probably limited by availability of nest structures and prey (Bull and Duncan 1993). In Yellowstone and Grand Teton National Parks and adjacent National Forests, most nests have been found in the lodgepole pine/Douglas fir/aspen zone (Wyoming Bioinformation Node's Species Atlas 1999).

Elevation: 1,500-3,000 m (Wyoming Bioinformation Node's Species Atlas 1999).

Comments: Designated as a species of interest by the Technical Advisory Committee to the Upper Yellowstone River Task Force. Study site is on southem edge of range. Egg laying peak is from beginning of April to end of May. Nestling stage peak is from late April to mid-July (Bull and Duncan 1993). Not commonly seen throughout most of their range (Clark et al. 1989:82). One of North America's most diurnal owls (Ehrlich et al. 1988:294).

\section{Boreal Owl (Aegolius funereus)}

Occurrence: Summer resident in Livingston latilong: indirect evidence of breeding has been recorded for QLL B. Summer resident in Bozeman, Yellowstone, and White Sulphur Springs latilongs; indirect evidence of breeding (Johnsgard 1986:213, Ellis et al. 1996:61).

\section{Abundance: Rare}

Diet: Voles (especially red-backed vole), mice, shrews, pocket gophers, squirrels, chipmunks, birds, insects (Hayward and Hayward 1993); rarely frogs and insects (Ehrlich et al. 1988:304).

Key Habitat Associations: Limited use of riparian habitats.

Foraging: Forest-associate. Mature-old forest stands of spruce-fir are important foraging habitat year round (Wyoming Bioinformation Node's Species Atlas 1999). In winter, the owls favor mature forest because uncrusted snow facilitates access to prey; in summer, mature forests have less herbaceous cover than open habitats, allowing greater access to prey. After spring thaw and before herbaceous 
vegetation becomes dense, owls shift to openings where vole densities exceed densities in forested stands (Hayward and Hayward 1993). Primary vegetation cover types in Wyoming are lodgepole pine and spruce-fir (Wyoming Bioinformation Node's Species Atlas 1999).

Breeding: In Rocky Mountains, breeding range is in subalpine forests of subalpine fir and Engelmann spruce, mostly above $1,580 \mathrm{~m}$. Uses secondary cavities made by woodpeckers. Prefers older forest stands but will use younger stands when boxes are provided (Hayward and Hayward 1993). Small patches of large aspen or ponderosa pine that have abundant cavities and are within spruce-fir zone may be ideal habitat (Wyoming Bioinformation Node's Species Atlas 1999).

Elevation: 1,350-3,600 m (Wyoming Bioinformation Node's Species Atlas 1999).

Comments: Designated as a species of interest by the Technical Advisory Committee to the Upper Yellowstone River Task Force. Study site is on southern tip of range (National Geographic Society 1999:256). Due to nocturnal activity and winter courtship, the owl's distribution has been difficult to determine. Prior to 1981, the North American range was believed limited to Canada and Alaska, but since then breeding populations have been documented in Washington, Idaho, Montana, and more southern areas (Clark et al. 1989:84-85). Singing begins mid-February to mid-April, depending on year. Egg laying peak is from early April to end of May. Nestling stage peak is from second week of May to end of June (Hayward and Hayward 1993).

\section{Belted Kingfisher (Ceryle alcyon)}

Occurrence: Year-round resident in Livingston latilong; breeding confirmed: direct evidence of breeding has been recorded for QLL A and C. Year-round resident in Bozeman and Yellowstone latilongs; breeding confirmed prior to 1991. Summer resident in Columbus latilong; breeding confirmed prior to 1991; indirect evidence of breeding in White Sulphur Springs latilong. Montana nesting records are for 17 April to 4 June (Johnsgard 1986:229, Ellis et al. 1996:65).

\section{Abundance: Uncommon}

Diet: Primarily fish inhabiting shallows or near water surface; crayfish in turbid waters (Hamas 1994). Also takes aquatic invertebrates, amphibians, reptiles, insects, young birds, mice, rarely berries (Ehrlich et al. 1988:336).

Key Habitat Associations: Riparian obligate.

Foraging: Requires clear waters and abundant perches for prey detection. Habitats include streams, rivers, ponds, lakes, and estuaries or calm marine waters. Primary vegetation cover types in Wyoming are forest-dominated and shrub-dominated riparian (Wyoming Bioinformation Node's Species Atlas 1999). Foraging microhabitat guild is aquatic bird (Skagen et al. 1998).

Breeding: Breeds near waters that are typically open and nunning, not turbid or overgrown with vegetation. Nests are tunneled into banks. Bank composition is generally sandy clay. (Banks composed primarily of clay, gravel, or rocks are generally unsuitable.) Banks with herbaceous vegetation are preferred to banks with tree roots, since tree roots impede nest excavation. Nests are near top of bank (within 35-64 cm), possibly to deter predation and to preclude flooding (Hamas 1994). Nests are occasionally in tree cavities (Ehrlich et al. 1988:336).

Elevation: 900-3,000 m (Wyoming Bioinformation Node's Species Atlas 1999).

Comments: Surrounding landscape may include a wide variety of terrestrial communities; availability of suitable nesting sites is likely a critical factor determining local abundance (Hamas 1994). 


\section{Lewis' Woodpecker (Melanerpes lewisi)}

Occurrence: Summer resident in Livingston latilong; indirect evidence of breeding was recorded prior to 1991. Year-round resident in Bozeman latilong; breeding confirmed prior to 1991. Summer resident in Yellowstone, White Sulphur Springs, and Columbus latilongs breeding confirmed prior to 1991. Occurs in Montana from early May to early October (Johnsgard 1986:230, Ellis et al. 1996:65).

\section{Abundance: Rare}

Diet: Insects older than larval stage, principally ants, bees, and wasps; also beetles and grasshoppers. Vegetable foods include acorns, cultivated nuts, and cultivated and wild fruits (Tobalske 1997).

Key Habitat Associations: Limited use of riparian habitats.

Foraging: Forest-associate. Three principal habitats are open riparian woodland dominated by cottonwood, open ponderosa pine forest, and logged or burned pine forest. Breeding birds also occur in oak woodland, nut and fruit orchards, pinyon pine-juniper woodland, a variety of pine and fir forests, and agricultural areas including farmland and ranchland (Tobalske 1997). Associated primarily with pine forests that are open and with burned areas having abundant snags or stumps (Johnsgard 1986:230). Primary vegetation cover types in Wyoming are ponderosa pine and lodgepole pine forests (Wyoming Bioinformation Node's Species Atlas 1999).

Breeding: Nests in tree cavities that are naturally occurring or excavated by other woodpeckers, or in highly decayed wood (LEWO has weak excavation morphology relative to other woodpeckers). Important breeding habitat features are open canopy, brushy understory offering ground cover, dead or downed woody material, available perches, and abundant insects (Tobalske 1997).

Elevation: 900-2,700 m (Wyoming Bioinformation Node's Species Atlas 1999).

Comments: Designated as a species of interest by the Technical Advisory Committee to the Upper Yellowstone River Task Force. Priority II species designation (second highest priority, recommendation of monitoring and/or conservation action) by Montana Partners in Flight (2000). Study site is in northeastern edge of range (Johnsgard 1986:230, Tobalske 1997).

\section{Red-naped Sapsucker (Sphyrapicus nuchalis)}

Occurrence: Summer resident in Livingston latilong; breeding confirmed: direct evidence of breeding has been recorded for QLL A and C. Summer resident in Bozeman, Yellowstone, White Sulphur Springs, and Columbus latilongs; breeding confirmed prior to 1991. In Montana, occurs from mid-April to mid-October. Nestlings have been observed in Montana from late June to mid-July (Johnsgard 1986:233, Ellis et al. 1996:66).

\section{Abundance: Uncommon}

Diet: Primarily insects; secondarily tree sap and pine pitch; also cambium, fruit, and berries (Ehrlich et al. 1988:350).

Key Habitat Associations: Occasional use of riparian habitats.

Foraging: Associated with forests, coniferous, deciduous, and mixed. Aspens are a preferred habitat in the Rocky Mountains (Johnsgard 1986:233). In Wyoming, found in aspen and cottonwood riparian 
habitats from 2,300 to $3,000 \mathrm{~m}$. During migration, coniferous forests and lower elevation habitats are used. Appears to be restricted to certain local habitat conditions rather than latitudinal zones (Wyoming Bioinformation Node's Species Atlas 1999). Associated patch and landscape-level features (for southeastern Idaho) are open canopies, natural (non-agricultural) landscapes, and areas in which cottonwood patches are near each other (Saab 1999). Foraging microhabitat guild is gleaner on trunk and branches (Skagen et al. 1998).

Breeding: Nests are cavities in live deciduous trees, including birch, cottonwood, and aspen, often near water. Same tree is often used perennially, though same hole may not be (Ehrlich et al. 1988:350). Elevation: 1,200-2,700 m (Wyoming Bioinformation Node's Species Atlas 1999).

Comments: Priority II species designation (second highest priority, recommendation of monitoring and/or conservation action) by Montana Partners in Flight (2000). At high risk of extinction in the Greater Yellowstone Ecosystem (Hansen et al. 1999).

\section{Downy Woodpecker (Picoides pubescens)}

Occurrence: Year-round resident in Livingston latilong; breeding confirmed: direct evidence of breeding has been recorded for QLL A; there is a transient/migrant record for C. Year-round resident in Bozeman, Yellowstone, White Sulphur Springs, and Columbus latilongs; breeding confirmed prior to 1991. Wyoming egg records are from as early as 15 April, and nestlings have been recorded as late as 20 July (Johnsgard 1986:235, Ellis et al. 1996:66).

\section{Abundance: Uncommon}

Diet: Insects (75-85\%); fruit, seeds, and sap from sapsucker holes (Ehrlich et al. 1988:350).

Key Habitat Associations: Occasional use of riparian habitats.

Foraging: Occurs in a wide variety of habitats, ranging from riparian forests to pinyon-juniper woodlands, oak-mountain mahogany scrub, and aspen or coniferous forests; also occurs in farm lots, orchards, and city parks (Johnsgard 1986:235). In Wyoming, found in all forested riparian types and in clearcut forests in northwestern Wyoming (Wyoming Bioinformation Node's Species Atlas 1999). Associated patch and landscape-level features (for southeastern Idaho) are bare ground and agricultural landscapes (Saab 1999). In cottonwood riparian habitats of Montana, strongly associated with stands with understory (Scott et al., in review).

Breeding: Nest is in cavity of a snag, often with entrance camouflaged by surrounding fungus, lichen, or moss. A new hole is built yearly (Ehrlich et al. 1988:350).

Elevation: 900-3,000 m (Wyoming Bioinformation Node's Species Atlas 1999).

\section{Black-backed Woodpecker (Picoides arcticus)}

Occurrence: Summer resident in Livingston latilong; direct evidence of breeding was recorded prior to 1991. Summer resident in Bozeman latilong; indirect evidence of breeding. Year-round resident in Yellowstone latilong; breeding confirmed. In Montana, fledglings have been observed in mid-July (Johnsgard 1986:239, Ellis et al. 1996:67). 
Diet: Mostly larvae of wood boring beetles, ants; some fruit, mast, and cambium (Ehrlich et al. 1988:354).

Key Habitat Associations: Limited use of riparian habitats.

Foraging: A fire-adapted species, typically moving into a burned forest area immediately after a fire, breeding, and then dispersing 4 or 5 years later (Johnsgard 1986:238-239). Associated with aspen, lodgepole pine, jack pine, Larix species, Douglas fir, and juniper. Found in bur oak woodlands in Black Hills region of Wyoming, and mesic upland shrubs south of Flaming Gorge reservoir. Primary vegetation cover types in Wyoming are lodgepole pine, ponderosa pine, and burned conifer (Wyoming Bioinformation Node's Species Atlas 1999, Clark et al. 1989:88).

Breeding: Nests in cavities, often in firs (Ehrlich et al. 1988:354). Nest cavities are often conspicuous for two reasons: they are excavated at low heights, typically 1 to $5 \mathrm{~m}$ from the ground; and bark around the cavity is removed, exposing the yellow cambium (Clark et al. 1989:89).

Elevation: 900-2,700 m; upper elevation range depends on montane subalpine division (Wyoming Bioinformation Node's Species Atlas 1999).

Comments: Designated as a species of interest by the Technical Advisory Committee to the Upper Yellowstone River Task Force. Priority I species designation (highest priority, recommendation of conservation action) by Montana Partners in Flight (2000). At high risk of extinction in the Greater Yellowstone Ecosystem (Hansen et al. 1999). Study site is in southern tip of year-round range (Johnsgard 1986:239, National Geographic Society 1999:282).

\section{Northern Flicker (Colaptes auratus)}

Occurrence: Year-round resident in Livingston latilong; breeding confirmed: direct evidence of breeding has been recorded for QLL A and C; there is a transient/migrant record for D. Year-round resident in Bozeman, White Sulphur Springs, and Yellowstone latilongs; breeding confirmed prior to 1991. Summer resident in Columbus latilong; breeding confirmed prior to 1991. Wyoming egg records are from 1 May to 4 June (Johnsgard 1986:240, Ellis et al. 1996:68).

\section{Abundance: Common}

Diet: Insects, especially ants; occasionally seeds, acoms, nuts, and grains (Ehrlich et al. 1988:338).

Key Habitat Associations: Occasional use of riparian habitats.

Foraging: Associated with open woodlands with grassy areas used in foraging for ants (Johnsgard 1986:240). In Wyoming, uses most habitats where trees or poles are present for nesting, including suburban areas (Wyoming Bioinformation Node's Species Atlas 1999). Associated patch and landscape-level features (for southeastern Idaho) are open canopies and subcanopies, and areas in which cottonwood patches are near each other (Saab 1999). Foraging microhabitat guild is gleaner in forb layer, ground, and litter (Skagen et al. 1998).

Breeding: Nest is usually in a snag but may be in other cavities: posts, houses, banks, haystacks, and boxes. Nest is perennial. Flickers occasionally usurp the burrows of Belted kingfishers and Bank swallows (Ehrlich et al. 1988:338).

Elevation: 900-3,150 m (Wyoming Bioinformation Node's Species Atlas 1999). 


\section{Olive-sided Flycatcher (Contopus borealis)}

Occurrence: Summer resident in Livingston latilong; indirect evidence of breeding has been recorded for QLL A; direct evidence of breeding was recorded for the latilong prior to 1991. Summer resident in Bozeman and Yellowstone latilongs; breeding confirmed. Summer resident in White Sulphur Springs and Columbus latilongs; indirect evidence of breeding. Occurs in Wyoming from 16 May to 18 September. Colorado egg records are from 16 June to 20 July (Johnsgard 1986:242, Ellis et al. 1996:69).

Abundance: Uncommon

Diet: Insects that can be captured in air; many honeybees (Ehrlich et al. 1988:376).

Key Habitat Associations: Occasional use of riparian habitats.

Foraging: Associated with coniferous montane forests, burned-over forests, and muskeg areas. Tall conifers and open, often boggy or meadow-like areas are typically present in these habitats (Johnsgard 1986:242). In Colorado, associated with edges between mature conifers and meadows; also associated with dead-topped trees and little canopy cover. Found near lake edges, streams, and agricultural lands during migration. Primary vegetation cover types in Wyoming are lodgepole pine, subalpine meadow, and spruce-fir (Wyoming Bioinformation Node's Species Atlas 1999).

Breeding: Nest is high in a coniferous tree (occasionally deciduous), from 1.5 to $23 \mathrm{~m}$ above ground (Ehrlich et al. 1988:376).

Elevation: 1,350-3,300 m (Wyoming Bioinformation Node's Species Atlas 1999).

Comments: Priority I species designation (highest priority, recommendation of conservation action) by Montana Partners in Flight (2000). At high risk of extinction in the Greater Yellowstone Ecosystem (Hansen et al. 1999).

\section{Western Wood-pewee (Contopus sordidulus)}

Occurrence: Summer resident in Livingston latilong; indirect evidence of breeding has been recorded for QLL A; there are transient/migrant records for B and C; direct evidence of breeding was recorded for the latilong prior to 1991. Summer resident in Bozeman, Yellowstone, and Columbus latilongs; breeding confirmed prior to 1991. Breeding confirmed in White Sulphur Springs latilong. Occurs in Montana from mid-May to mid-September. Wyoming egg records are from 20 June to 15 July (Johnsgard 1986:243, Ellis et al. 1996:69).

\section{Abundance: Common}

Diet: Almost entirely insects; rarely berries (Ehrlich et al 1988:378).

Key Habitat Associations: Riparian associate.

Foraging: Forest-associate. Associated primarily with open coniferous forests but also riparian forests, aspens, and various open deciduous or mixed woodland habitats (Johnsgard 1986:243). In Montana, occur mostly in riparian areas and open conifers (Hutto and Young 1999). In Wyoming, found in mature pine forest but notably absent from dense spruce forest. Found in burned conifer areas in Yellowstone National Park and Bighorn mountains. A study in southern Wyoming found higher abundances in aspen than in mixed or coniferous forests (Wyoming Bioinformation Node's Species Atlas 
1999). Associated patch and landscape-level features (for southeastern Idaho) are open canopies, willow subcanopies, agricultural and homogeneous landscapes, and areas in which cottonwood patches are near each other (Saab 1999). In cottonwood riparian habitats of Montana, strongly associated with complex stands with understory (Scott et al., in review). Foraging microhabitat guild is aerial insectivore-sallying and hawking (Skagen et al. 1998).

Breeding: Nests in conifers (Ehrlich et al. 1988:378). In Colorado, nests in mixed woods near water (Wyoming Bioinformation Node's Species Atlas 1999).

Elevation: 900-3,000 m. Common at all elevations but especially 1,520-1,830 m (Wyoming Bioinformation Node's Species Atlas 1999).

Comments: At high risk of extinction in the Greater Yellowstone Ecosystem (Hansen et al. 1999).

\section{Willow Flycatcher (Empidonax traillii)}

Occurrence: Summer resident in Livingston latilong; breeding confirmed: indirect evidence of breeding has been recorded for QLL A; direct evidence for B. Summer resident in Bozeman and Columbus latilongs indirect evidence of breeding. Summer resident in Yellowstone and White Sulphur Springs latilongs; breeding confirmed. Occurs in Montana from mid-May to early September (Johnsgard 1986:246, Ellis et al. 1996:70).

Abundance: Uncommon

Diet: Insects, berries, and rarely seeds (Ehrlich et al. 1988:388).

Key Habitat Associations: Riparian obligate.

Foraging: An edge-adapted species associated with riparian or wetland habitats. Needs at least $20 \%$ shrub cover, which may include willow, alder, water birch, and hawthorne. Also uses mesic upland shrub. Found in bur oak woodlands of Black Hills region of Wyoming, dryland crops (CRP acreage) in southeast Wyoming, and irrigated hayfields of southwest Wyoming (Wyoming Bioinformation Node's Species Atlas 1999). Foraging microhabitat guild is aerial insectivore-sallying and hawking (Skagen et al. 1998).

Breeding: Breeds in river bottom aspen stands, whereas Dusky and Hammond's flycatchers inhabit upland aspen forests. According to Colorado sources, breeds in aspen, cottonwood-willow, mountain meadows, mountain shrubs, riparian areas, woodlands, and alder near streams and ponds (Wyoming Bioinformation Node's Species Atlas 1999). Nest is built in an upright or slanting fork of a shrub or deciduous tree, approximately 1 to $3 \mathrm{~m}$ above ground (Ehrlich et al. 1988:388).

Elevation: 900-2,850 m (Wyoming Bioinformation Node's Species Atlas 1999).

Comments: Designated as a species of interest by the Technical Advisory Committee to the Upper Yellowstone River Task Force. Priority II species designation (second highest priority, recommendation of monitoring and/or conservation action) by Montana Partners In Flight (2000). At high risk of extinction in the Greater Yellowstone Ecosystem (Hansen et al. 1999).

\section{Least Flycatcher (Empidonax minimus)}

Occurrence: Summer resident in Livingston latilong; indirect evidence of breeding was recorded prior to 1991. Summer resident in Bozeman and Columbus latilongs; breeding confirmed prior to 1991. Indirect 
evidence of breeding in Yellowstone and White Sulphur Springs latilongs. Occurs in Montana in early May to late August (Johnsgard 1986:247, Ellis et al. 1996:70).

Abundance: Common

Diet: Primarily arthropods; also berries and rarely seeds (Ehrlich et al. 1988:384, Briskie 1994).

Key Habitat Associations: Riparian associate.

Foraging: Broad habitat preferences associated with open and edge-dominated habitats (Johnsgard 1986:247). Habitats include semi-open, second-growth, and mature deciduous and mixed woods; occasionally conifer groves, burns, swamps and bog edges, orchards, shrubby fields; occurs near open spaces (forest clearings and edges, water, roads, cottage clearings); also abundant in dense and closed canopy forests (Briskie 1994). According to Colorado sources, requires open woods near water. Found in mesic upland shrub types near Devil's Tower National Monument (Wyoming Bioinformation Node's Species Atlas 1999). In cottonwood riparian habitats of Montana, prefers stands with understory (Scott et al., in preparation). Foraging microhabitat guild is aerial insectivore-sallying and hawking (Skagen et al. 1998).

Breeding: Nests are generally built in lower to middle portion of canopy, in a wide variety of trees and some shrubs (Ehrlich et al. 1988:384, Briskie 1994).

Elevation: 900-3,000 m (Wyoming Bioinformation Node's Species Atlas 1999).

Comments: Designated as a species of interest by the Technical Advisory Committee to the Upper Yellowstone River Task Force. At high risk of extinction in the Greater Yellowstone Ecosystem (Hansen et al. 1999).

\section{Hammond's Flycatcher (Empidonax hammondii)}

Occurrence: Summer resident in Livingston latilong; breeding confirmed: indirect evidence of breeding has been recorded for QLL A; direct evidence for C. Summer resident in Bozeman, Yellowstone, and White Sulphur Springs latilongs; breeding confirmed prior to 1991 in Bozeman latilong. There is a transient/ migrant record for Columbus latilong. Occurs in Montana from early May to late August (Johnsgard 1986:248, Ellis et al. 1996:70).

Abundance: Uncommon

Diet: Insects (Ehrlich et al. 1988:386).

Key Habitat Associations: Occasional use of riparian habitats.

Foraging: Occurs in cool forest and woodland. Prefers dense fir forests but also inhabits ponderosa and lodgepole pine, spruce, Douglas fir, aspen, alder, and dogwood (Sedgwick 1994). Other habitats are willow- and alder-lined mountain streams, edges of clearings, timbered riparian sites and ravines, and mesic upland shrub areas. Canopy can range from closed to open. Primary vegetation cover types in Wyoming are lodgepole pine, spruce-fir, and Douglas fir (Wyoming Bioinformation Node's Species Atlas 1999).

Breeding: In western Montana, all nests $(n=8)$ were observed in mature Douglas firs or ponderosa pines and saddled on horizontal branches at approximately $7.5 \mathrm{~m}$ above ground (Sedgwick 1994).

Elevation: 1,350-3,300 m, elevations may be lower outside of breeding season (Wyoming Bioinformation Node's Species Atlas 1999). 
Comments: Designated as a species of interest by the Technical Advisory Committee to the Upper Yellowstone River Task Force. Priority II species designation (second highest priority, recommendation of monitoring and/or conservation action) by Montana Partners in Flight (2000). Study site is on eastern edge of breeding range (Johnsgard 1986:248, Sedgwick 1994).

\section{Dusky Flycatcher (Empidonax oberholseri)}

Occurrence: Summer resident in Livingston latilong; breeding confirmed: indirect evidence of breeding has been recorded for QLL A, B, and D; direct evidence for C. Summer resident in Bozeman and Yellowstone latilongs; breeding confirmed in both latilongs prior to 1991. Indirect evidence of breeding in White Sulphur Springs and Columbus latilongs. Occurs in Montana from early May to late August. Montana egg records are from mid- to late July (Johnsgard 1986:249, Ellis et al. 1996:71).

\section{Abundance: Common}

Diet: Insects during breeding season; unknown for nonbreeding season (Sedgwick 1993).

Key Habitat Associations: Occasional use of riparian habitats.

Foraging: Associated with open woodland and shrubby habitats, including riparian edges, oak-mountain mahogany woodlands, aspen groves, and open ponderosa pine woods. In Montana, commonly found in brushy, logged-over slopes (Johnsgard 1986:249). In western Montana, occurs in mixed ponderosa pine/Douglas-fir forest, thinned coniferous forest, logged-over slopes, with shrubby openings preferred (Sedgwick 1993). In Wyoming, observed in thickets of chokecherry, dogwood, willow and aspen. In southwest Wyoming, occurs in burned conifer and forested areas near water (Wyoming Bioinformation Node's Species Atlas 1999). Associated patch and landscape-level features (for southeastern Idaho) are litter ground cover, bare ground, natural (non-agricultural) landscapes, and large patch size (Saab 1999). Foraging microhabitat guild is aerial insectivore-sallying and hawking (Skagen et al. 1998).

Breeding: Nest is usually in an upright crotch of a shrub, less than $5 \mathrm{~m}$ above ground and typically around $2 \mathrm{~m}$ above ground. In western Montana, nests are often in mallow ninebark and Rocky Mountain maple bushes (Sedgwick 1993).

Elevation: 900-3,000 m (Wyoming Bioinformation Node's Species Atlas 1999).

Comments: At high risk of extinction in the Greater Yellowstone Ecosystem (Hansen et al. 1999).

\section{Cordilleran Flycatcher (Empidonax occidentalis)}

Occurrence: Summer resident in Livingston latilong; there is a transient/migrant record for QLL A and indirect evidence of breeding for C. Summer resident in Yellowstone latilong; breeding confirmed. Indirect evidence of breeding in Bozeman, White Sulphur Springs, and Columbus latilongs. Occurs in Montana from late May to August (Johnsgard 1986:251, Ellis et al. 1996:71).

\section{Abundance: Uncommon}

Diet: Insects; rarely berries and seeds (Ehrlich et al. 1988:390). 
Key Habitat Associations: Riparian associate.

Foraging: Occurs in a variety of habitats associated with water, including moist wooded canyons, mountain meadows, canyon bottoms, and riparian woodlands. Structure varies from tall trees to low shrubs. Avoids dense thickets. May be found in aspen and coniferous zones, including spruce-fir. Moves up slope to meadow-forest edge and into sagebrush areas after breeding. Found in bur oak woodlands in Black Hills region of Wyoming and human settlements such as Green River and Rock Springs, Wyoming (Wyoming Bioinformation Node's Species Atlas 1999). Foraging microhabitat guild is aerial insectivore-sallying and hawking (Skagen et al. 1998).

Breeding: Nests in a wide variety of situations, from stream bank or roots of upturned tree to eaves, cliff ledges, and cavities in small trees (Ehrlich et al. 1988:390). According to Colorado sources, breeds in Gambel oak, aspen, cottonwood-willow, lodgepole, spruce fir, ponderosa pine, Douglas fir, sage, and rabbitbrush (Wyoming Bioinformation Node's Species Atlas 1999).

Elevation: 1,050-2,700 m (Wyoming Bioinformation Node's Species Atlas 1999).

Comments: Designated as a species of interest by the Technical Advisory Committee to the Upper Yellowstone River Task Force. Priority II species designation (second highest priority, recommendation of monitoring and/or conservation action) by Montana Partners in Flight (2000).

\section{Eastern Kingbird (Tyrannus tyrannus)}

Occurrence: Summer resident in Livingston latilong; indirect evidence of breeding has been recorded for QLL A and B; there is a transient/migrant record for C; direct evidence of breeding was recorded for the latilong prior to 1991. Summer resident in Bozeman, Yellowstone, and Columbus latilongs; breeding confirmed prior to 1991. Direct evidence of breeding in White Sulphur Springs latilong. Occurs in Montana from early May to mid-September (Johnsgard 1986:258, Ellis et al. 1996:73).

Abundance: Common

Diet: Insects during breeding season; supplemented with fruit as summer progresses and during nonbreeding season (Murphy 1996).

Key Habitat Associations: Riparian associate.

Foraging: Associated with open environments, including fields with scattered shrubs and trees, orchards, shelterbelts, and especially woodland edges in forested regions (Murphy 1996). In Wyoming, associated with low elevation riparian areas, including peripheries of pastures, fields, ponds, lakes, and streams (Wyoming Bioinformation Node's Species Atlas 1999). Associated patch features (for southeastern Idaho) include open canopies (Saab 1999).

Breeding: Apparently attracted to water; nests often occur in trees overhanging water or in snags surrounded by water, perhaps to moderate temperature fluctuations (Murphy 1996).

Elevation: 900-2,400 m (Wyoming Bioinformation Node's Species Atlas 1999).

Comments: Tolerant of ecological change (Wyoming Bioinformation Node's Species Atlas 1999).

\section{Plumbeous Vireo (Vireo plumbeus); formerly a subspecies of Solitary Vireo (Vireo solitarius)}

Occurrence: Summer resident in Livingston latilong; indirect evidence of breeding has been recorded for QLL A. Summer resident in Bozeman, Yellowstone, White Sulphur Springs, and Columbus latilongs; 
breeding unconfirmed. Occurs in Montana from early to mid-May to mid-September. Active nests have been observed in Montana from mid-June to mid-July (Johnsgard 1986:319, Ellis et al. 1996:89).

Abundance: Uncommon

Diet: Almost entirely insects; fleshy fruits compose $25 \%$ of diet in January, but only $4 \%$ year-round (Ehrlich et al. 1988:494).

Key Habitat Associations: Occasional use of riparian habitats.

Foraging: Open, coniferous, or mixed forests with considerable undergrowth seem to be favored. Forests are typically dry and warm rather than cool and moist. Trees typically have open branches for foraging at low to medium tree levels. Forest types include conifer forests with aspen stands, cottonwood-riparian, Gambel's oak-mountain mahogany woodland, bur oak woodland, and pine-juniper. Primary vegetation cover types in Wyoming are ponderosa pine and juniper woodland (Wyoming Bioinformation Node's Species Atlas 1999).

Breeding: Nests are usually in lower branches of pines or oaks, often less than $2 \mathrm{~m}$ above ground (Johnsgard 1986:319).

Elevation: 900-2,550 m (Wyoming Bioinformation Node's Species Atlas 1999).

Comments: Study site is on northern edge of breeding range (National Geographic Society 1999:308).

\section{Warbling Vireo (Vireo gilvus)}

Occurrence: Summer resident in Livingston latilong; breeding confirmed. Direct evidence of breeding has been recorded for QLL A, B, and C; indirect evidence for D. Summer resident in Bozeman, Yellowstone, and White Sulphur Springs latilongs; breeding confirmed. Indirect evidence of breeding in Columbus latilong. Occurs in Montana from mid-May to early to mid-September. Wyoming and Montana egg records are from 15 June to 13 July (Johnsgard 1986:320, Ellis et al. 1996:89).

\section{Abundance: Common}

Diet: Almost entirely insects; some spiders; few berries (Ehrlich et al. 1988:498).

Key Habitat Associations: Riparian associate.

Foraging: Associated with open woodlands, especially of deciduous trees. Common along riparian forests supporting tall trees, in aspen groves, and in well-wooded residential or park areas where tall cottonwoods are present. In coniferous forests, deciduous trees such as aspen and birch are preferred; foraging is done near the crowns (Johnsgard 1986:320). In Wyoming, occurs in streamside thickets in canyons, hollows, and gulches. Often shares same habitat with red-eyed vireo (Wyoming Bioinformation Node's Species Atlas 1999). Associated patch and landscape-level features (for southeastern Idaho) are herbaceous ground cover, natural (non-agricultural) landscapes, and large patch size (Saab 1999). Foraging microhabitat guild is foliage gleaner in middle and upper canopy (Skagen et al. 1998).

Breeding: Nest is typically high in a deciduous tree or shrub, ranging from 1 to $27 \mathrm{~m}$ above ground (Ehrlich et al. 1988:498).

Elevation: $900-3,000 \mathrm{~m}$; up to 2,650 $\mathrm{m}$ in Yellowstone (Wyoming Bioinformation Node's Species Atlas 1999). 
Comments: Most common and widespread vireo of the Rocky Mountains from Colorado to Montana (Johnsgard 1986:320).

\section{Red-eyed Vireo (Vireo olivaceus)}

Occurrence: Summer resident in Livingston latilong; there is a transient/migrant record for QLL A; indirect evidence of breeding was recorded for the latilong prior to 1991. Summer resident in Bozeman latilong; breeding confirmed prior to 1991. Indirect evidence of breeding in Yellowstone, White Sulphur Springs, and Columbus latilongs. Occurs in Montana from mid-May to early September. Active nests have been recorded in Montana from mid-June to early August (Johnsgard 1986:322, Ellis et al. 1996:90).

Abundance: Uncommon

Diet: Almost entirely insects; snails, spiders fed to young. Entirely fruit on wintering grounds (Ehrlich et al. 1988:496).

Key Habitat Associations: Riparian obligate.

Foraging: Primarily associated with deciduous forests. In Rocky Mountains, largely limited to broadleaved riparian forests in prairie areas, aspen groves and poplars growing among conifers, and to planted areas in city parks and farmsteads (Johnsgard 1986:322). In Montana, restricted to cottonwood bottomland forests (Hutto and Young 1999). Associated with semi-open canopies and a shrubby stratum or thicket of young trees. Generally prefers dense understory. Primary vegetation cover types in Wyoming are forest-dominated riparian and unclassified riparian (Wyoming Bioinformation Node's Species Atlas 1999).

Breeding: Nest is typically in shrub or deciduous tree. It averages 1.5 to $11 \mathrm{~m}$ above ground and is often located fairly conspicuously (Ehrlich et al. 1988:496, Johnsgard 1986:322).

Elevation: 900-2,250 m (Wyoming Bioinformation Node's Species Atlas 1999).

Comments: Designated as a species of interest by the Technical Advisory Committee to the Upper Yellowstone River Task Force. Priority II species designation (second highest priority, recommendation of monitoring and/or conservation action) by Montana Partners in Flight (2000). Study site is on southern edge of breeding range (Johnsgard 1986:322, National Geographic Society 1987).

\section{Black-billed Magpie (Pica pica)}

Occurrence: Year-round resident in Livingston latilong; breeding confirmed. Direct evidence of breeding has been recorded for QLL A, B, and C. Year-round resident in Bozeman, Yellowstone, White Sulphur Springs, and Columbus latilongs; breeding confirmed. Montana egg records range from late March to late May, peaking between 6 May and 12 May (Johnsgard 1986:275, Ellis et al. 1996:77).

\section{Abundance: Common}

Diet: Omnivorous. 85\% insects, carrion, invertebrates, and small vertebrates; $15 \%$ fruit and seeds (Ehrlich et al. 1988:414). 
Key Habitat Associations: Riparian associate.

Foraging: Occurs widely, but especially common in riparian areas with thickets, agricultural areas with scattered trees, sagebrush, aspen groves, and the lower levels of coniferous forest zones (Johnsgard 1986:275). In Wyoming, other habitats are sagebrush-grasslands, riparian habitats, juniper, limber pine, human settlements, bur oak woodland, foothills grassland, desert shrub, saltbrush, greasewood fans and flats, Douglas fir forests, subalpine meadows, and basin exposed rock/soil and surface mining (Wyoming Bioinformation Node's Species Atlas 1999). Associated patch and landscape-level features (for southeastern Idaho) are herbaceous ground cover, bare ground, heterogeneous landscapes, small patches, and areas in which cottonwood patches are near each other (Saab 1999).

Breeding: Nest is built in deciduous or coniferous tree or shrub. It is large and conspicuous, with a bulky dome covering the entire structure (Ehrlich et al. 1988:414). Small, thorny trees are favored nest sites, but junipers and similar trees are also used (Johnsgard 1986:275). Nest is frequently along rivers and near ponds (Wyoming Bioinformation Node's Species Atlas 1999).

Elevation: 900-2,700 m (Wyoming Bioinformation Node's Species Atlas 1999).

\section{American Crow (Corvus brachyrhynchos)}

Occurrence: Year-round resident in Livingston latilong; breeding confirmed. Indirect evidence of breeding has been recorded for QLL A and B; direct evidence for C. Year-round resident in Bozeman and Yellowstone latilongs; breeding confirmed prior to 1991. Summer resident in White Sulphur Springs and Columbus latilongs; breeding confirmed prior to 1991. Occurs in Montana from late March to October, with a few overwintering in most years. Wyoming egg records are from 5 May to 1 July (Johnsgard 1986:276, Ellis et al. 1996:77).

\section{Abundance: Common}

Diet: Omnivorous. Insects, other invertebrates, carrion, small vertebrates, bird eggs, nestlings, seeds (especially com), fruits, and nuts (Ehrlich et al. 1988:416).

Key Habitat Associations: Occasional use of riparian habitats.

Foraging: Occurs in a wide variety of habitats, including forested areas, wooded river bottoms, orchards, woodlots, large parks, and suburban areas. Often replaced by ravens in rocky canyons and higher montane areas (Johnsgard 1986:276). In Wyoming, habitats include agricultural areas, riparian areas, desert scrub and sagebrush areas, bur oak woodlands, basin exposed rock/soil, and foothills grasslands (Wyoming Bioinformation Node's Species Atlas 1999). Associated patch and landscapelevel features (for southeastern Idaho) are open subcanopies, willow subcanopies, and natural (nonagricultural) landscapes (Saab 1999).

Breeding: Nest is built in deciduous or coniferous tree or shrub; rarely on ground (Ehrlich et al. 1988:414).

Elevation: 900-2,700 m (Wyoming Bioinformation Node's Species Atlas 1999).

\section{Black-capped Chickadee (Poecile atricapillus)}

Occurrence: Year-round resident in Livingston latilong; breeding confirmed. Direct evidence of breeding has been recorded for QLL A and C; there is a transient/migrant record for B. Year-round resident in Bozeman, Yellowstone, White Sulphur Springs, and Columbus latilongs; breeding confirmed. Montana egg records range from 12 May to 28 July (Johnsgard 1986:278, Ellis et al. 1996:78). 


\section{Abundance: Common}

Diet: Primarily insects, spiders, and spider eggs; secondarily conifer seeds and fruit (Ehrlich et al. 1988:424).

Key Habitat Associations: Riparian associate.

Foraging: Associated with a wide variety of wooded habitats, both coniferous and deciduous (Johnsgard 1986:278). In Wyoming, habitats include pine and spruce forests, aspen groves, river thickets and canyons, riparian habitats at foothills zone, bur oak woodlands, mesic upland shrubs, and montane forests near water. Colorado sources indicate association with cottonwoods along streams and a canopy closure of less than 70\% (Wyoming Bioinformation Node's Species Atlas 1999). Associated patch and landscape-level features (for southeastern Idaho) are bare ground, agricultural landscapes, and areas in which cottonwood patches are near each other (Saab 1999). In cottonwood riparian habitats of Montana, strongly associated with complex stands with understory (Scott et al., in review).

Breeding: Typically, nests are in old woodpecker holes but sometimes nests are excavated in rotted wood of dead stumps. Bird houses are occasionally used. In the Rocky Mountains, aspen groves and riparian woodlands are frequent nesting areas (Johnsgard 1986:278).

Elevation: 900-2,700 m (Wyoming Bioinformation Node's Species Atlas 1999).

\section{House Wren (Troglodytes aedon)}

Occurrence: Summer resident in Livingston latilong; breeding confirmed. Direct evidence of breeding has been recorded for QLL A and C; indirect evidence for D. Summer resident in Bozeman, Yellowstone, White Sulphur Springs, and Columbus latilongs breeding confirmed. Occurs in Montana from early May to late October. Wyoming egg records are from 1 June to 15 July (Johnsgard 1986:291, Ellis et al. 1996:81).

\section{Abundance: Abundant}

Diet: Insects, spiders, and snails (Ehrlich et al. 1988:438).

Key Habitat Associations: Riparian associate.

Foraging: Most abundant in lower elevation forests but occasionally reaching timberline. At lower elevations, habitats include riparian woodlands, aspen groves, open coniferous forests, and areas of human habitation (Johnsgard 1986:291). In Wyoming, populations appear to be limited by climatic factors and predation rather than by rigorous environmental requirements. Occurs throughout Wyoming except in desert areas with no trees (Wyoming Bioinformation Node's Species Atlas 1999). Associated patch and landscape-level features (for southeastern Idaho) are closed canopies, bare ground, agricultural and homogeneous landscapes, large patch size, and areas in which cottonwood patches are near each other (Saab 1999). In cottonwood riparian habitats of Montana, strongly associated with understory (Scott et al., in review). Foraging microhabitat guild is foliage gleaner in lower canopy and shrub layer (Skagen et al. 1998).

Breeding: Nest is usually in a natural hole but also woodpecker holes and birdhouses (Ehrlich et al. 1988:438, Johnsgard 1986:291). A study of snags used by house wrens found mean nest height to be $4 \mathrm{~m}$, mean nest tree height $15 \mathrm{~m}$, and mean nest tree diameter at breast height $40 \mathrm{~cm}$ (Wyoming Bioinformation Node's Species Atlas 1999).

Elevation: 900-2,850 m (Wyoming Bioinformation Node's Species Atlas 1999). 


\section{American Dipper (Cinclus mexicanus)}

Occurrence: Year-round resident in Livingston latilong; breeding confirmed. Indirect evidence of breeding has been recorded for QLL A; there is a transient/migrant record for B; direct evidence for C and D. Yearround resident in Bozeman and Yellowstone latilongs breeding confirmed. Summer resident in White Sulphur Springs and Columbus latilongs; breeding confirmed. In Glacier National Park, nest-building has been observed as early as 21 April (Johnsgard 1986:294, Ellis et al. 1996:82).

\section{Abundance: Common}

Diet: Stream insect fauna, particularly larval life stages: caddisflies, mayflies, stoneflies, and Diptera, including midges, craneflies, mosquitoes, etc. Rare food items: beetles, dragonflies, segmented worms, small fish, fish eggs, and tadpoles. Feeds almost exclusively in water by walking, swimming, and diving (Kingery 1996).

Key Habitat Associations: Riparian obligate.

Foraging: Throughout year, inhabits fast-moving, clear, unpolluted streams with cascades, riffles, and waterfalls. Aquatic vegetation is not favored. Stream bottoms contain rocks, sand, and rubble (habitats of aquatic invertebrates). Instream or streamside boulders are necessary for perches. Rocks, fallen trees, and driftwood provide cover for escape from predators and refuges for molting. Streamside landscape is not a critical factor, ranging from coniferous forest to prairie, sagebrush, urban areas, or barren ground (Kingery 1996). Primary vegetation cover types in Wyoming are unclassified riparian, shrub-dominated riparian, and forest-dominated riparian (Wyoming Bioinformation Node's Species Atlas 1999).

Breeding: Streams selected for breeding rarely exceed $15 \mathrm{~m}$ in width or $2 \mathrm{~m}$ in depth (in winter, stream width and depth may be greater). Stream banks must contain cliffs, large rocks, and boulders (especially those with overhanging ledges and crevices) for nest sites. Fallen logs and tree roots are sometimes used for nesting and roosting. Basic nest site requirements: close to water (usually fast and loud), inaccessible to predators (e.g., by being near deep, fast water), protected from floods, and a horizontal ledge or crevice for support. Nest is typically 1 to $3 \mathrm{~m}$ above water. Nests are frequently reused, with or without repairs (Kingery 1996).

Elevation: 1,200-3,150 m (Wyoming Bioinformation Node's Species Atlas 1999).

Comments: Availability of suitable nest sites is probably the principal limiting factor for distribution and abundance (Kingery 1996). Often shares habitat with Harlequin ducks (Johnsgard 1986:294).

\section{Ruby-crowned Kinglet (Regulus calendula)}

Occurrence: Summer resident in Livingston latilong; breeding confirmed. Direct evidence of breeding in QLL C, indirect evidence of breeding in QLL A and D. Year-round resident in Bozeman latilong; breeding confirmed. Summer resident in Yellowstone, White Sulphur Springs, and Columbus latilongs; breeding confirmed (Johnsgard 1986:296, Ellis et al. 1996:82).

\section{Abundance: Abundant}

Diet: Mostly small arthropods, including spiders, insects, and their eggs; small amounts of fruit, seeds, and other vegetable matter (Ingold and Wallace 1994). 
Key Habitat Associations: Occasional use of riparian habitats, especially in migration and winter. Foraging: Associated with tall dense coniferous forests. During winter moves to lower elevations, prairie stream bottoms, sometimes cities/towns (Johnsgard 1986). In Yellowstone, uses limber pinejuniper, Douglas fir, lodgepole pine, fir-whitebark pine, and spruce-fir. Colorado sources: occurs in aspen-conifer-willow and mixed conifer-aspen with openings around clearcuts, burns. Prefers low to intermediate canopy cover; open stands and edge. During migration and winter occupies a variety of habitats (Ingold and Wallace 1994) and is found in riparian, ponderosa pine and pine-juniper, farmstead trees, urban (Wyoming Bioinformation Node's Species Atlas 1999).

Breeding: In the western U.S., nests in spruce-fir, lodgepole pine, and Douglas fir trees. Elongated pensile nest is constructed an average of $12 \mathrm{~m}$ above ground (Ingold and Wallace 1994).

Elevation: $1,200-3,000 \mathrm{~m}$; lower elevations in migration.

\section{Veery (Catharus fuscescens)}

Occurrence: Summer resident in Livingston latilong; indirect evidence of breeding has been recorded for QLL A and B; direct evidence of breeding was recorded for the latilong prior to 1991. Summer resident in Bozeman, Yellowstone, and Columbus latilongs breeding confirmed prior to 1991. Indirect evidence of breeding in White Sulphur Springs latilong. Occurs in Montana from early May to early September and occasionally into early October (Johnsgard 1986:302, Ellis et al. 1996:84).

\section{Abundance: Common}

Diet: Roughly $60 \%$ insects and $40 \%$ fruit. Feeds primarily on insects during breeding and primarily fruit in late summer and fall. Small frogs and salamanders are sometimes eaten (Moskoff 1995).

Key Habitat Associations: Riparian associate.

Foraging: Primarily occurs in damp deciduous forests, preferring riparian habitats in parts of its range. A preference for disturbed forests is likely due to associated dense understory (Moskoff 1995). In Wyoming, uses wooded river valleys and canyons that range from deciduous gallery forests in prairie areas to aspen forests of foothills and willow-lined mountain streams. Areas with heavy thicket undergrowth are typical. In Colorado, willow and alder thickets near streams are commonly used (Wyoming Bioinformation Node's Species Atlas 1999). Moisture regime is main factor in habitat selection in mature woodlands, whereas shrub cover seems to be main consideration in disturbed woodlands (Moskoff 1995, Wyoming Bioinformation Node's Species Atlas 1999). Associated patch and landscape-level features (for southeastern Idaho) are open canopies, litter ground cover, willow subcanopies, large patch size, and areas in which cottonwood patches are near each other (Saab 1999).

Breeding: Nest is typically on or near ground, in (or at base of) shrub or small tree. Typical conditions are moist and shady, though nests are occasionally built on high, dry hillsides (Moskoff 1995).

Elevation: 900-2,700 m (Wyoming Bioinformation Node's Species Atlas 1999).

Comments: Designated as a species of interest by the Technical Advisory Committee to the Upper Yellowstone River Task Force. Priority II species designation (second highest priority, recommendation of monitoring and/or conservation action) by Montana Partners in Flight (2000). At high risk of extinction in the Greater Yellowstone Ecosystem (Hansen et al. 1999). Frequently parasitized by Brown-headed cowbirds (Johnsgard 1986:302). 


\section{Swainson's Thrush (Catharus ustulatus)}

Occurrence: Summer resident in Livingston latilong; breeding confirmed. Indirect evidence of breeding has been recorded for QLL A and D; direct evidence for C. Summer resident in Bozeman and Yellowstone latilongs; breeding confirmed prior to 1991. Indirect evidence of breeding in White Sulphur Springs and Columbus latilongs. Occurs in Wyoming from 9 May to 20 October. Montana egg records are from midJune onward (Johnsgard 1986:304, Ellis et al. 1996:85).

\section{Abundance: Common}

Diet: Insects and spiders; berries, especially in winter (Ehrlich et al. 1988:458).

Key Habitat Associations: Occasional use of riparian habitats.

Foraging: Occurs in high-elevation, shaded canyons with large areas of tangled brushy undergrowth: riparian thickets of alders and willow, and aspen slopes. On migration, may be found in any dense woodland (Johnsgard 1986:304). In Wyoming, habitats include aspen with thick understory and streamside thickets in mountains, deciduous woods and thickets at low elevations, bur oak and juniper woodlands, spruce forests, and occasionally mixed forests of spruce, aspen and birch (Wyoming Bioinformation Node's Species Atlas 1999). Associated patch and landscape-level features (for southeastern Idaho) are open canopies, dense willow subcanopies, and natural (non-agricultural) landscapes (Saab 1999). Foraging microhabitat guild is forest generalist (Skagen et al. 1998).

Breeding: Nest is usually in a small tree near water, from . 6 to $6 \mathrm{~m}$ above ground (Johnsgard 1986:304). Elevation: 1,200-3,000 m; lower elevations during migration (Wyoming Bioinformation Node's Species Atlas 1999).

Comments: Study area is in eastern edge of Rocky Mountain breeding range (Johnsgard 1986:304, National Geographic Society 1999:348).

\section{American Robin (Turdus migratorius)}

Occurrence: Year-round resident in Livingston latilong; breeding confirmed. Direct evidence of breeding has been recorded for QLL A, B, and C. Year-round resident in Bozeman and Yellowstone latilongs; breeding confirmed. Summer resident in White Sulphur Springs and Columbus latilongs; breeding confirmed. Where not year-round in Montana, occurrence is from February to November. In Montana, nestlings have been reported from late May to mid-August (Johnsgard 1986:306, Ellis et al. 1996:85).

\section{Abundance: Abundant}

Diet: Insects, earthworms, and snails; much fruit (Ehrlich et al. 1988:462).

Key Habitat Associations: Riparian associate.

Foraging: Occurs almost anywhere there are these three features: soft ground suitable for probing for insects and worms, mud available for nest building, and trees. Typical habitats are open woodlands (natural or artificial), such as those occurring in suburbs, city parks, and farmsteads (Johnsgard 1986:306). In Montana, most commonly detected in riparian habitats and early successional forests (Hutto and Young 1999). In Wyoming, habitats include pine and spruce forests, scrub oaks, aspen 
stands, cottonwoods, orchards, and residential areas. In winter, occurs in sheltered bottomlands and residential areas. In Yellowstone, occurs in foothills riparian, montane riparian, limber pine-juniper, Douglas fir, lodgepole pine, fir-whitebark pine, and spruce-fir forests. Grass-dominated areas are also suitable, including short, mixed, and foothill grasslands, meadow tundra, and grass-dominated wetlands. (Wyoming Bioinformation Node's Species Atlas 1999). Associated patch and landscape-level features (for southeasterm Idaho) are open canopies, bare ground, agricultural landscapes, small patches, and areas in which cottonwood patches are near each other (Saab 1999). In cottonwood riparian habitats of Montana, prefer stands with understory (Scott et al., in review). Foraging microhabitat guild is forest generalist (Skagen et al. 1998).

Breeding: Nests in deciduous or coniferous trees or shrubs, buildings, and occasionally on ground (Ehrlich et al. 1988:462).

Elevation: 900-3,150 m (Wyoming Bioinformation Node's Species Atlas 1999).

\section{Gray Catbird (Dumetella carolinensis)}

Occurrence: Summer resident in Livingston latilong; breeding confirmed. Direct evidence of breeding has been recorded for QLL A; indirect evidence for B; there is a transient/migrant record for C. Summer resident in Bozeman, Yellowstone, and Columbus latilongs; breeding confirmed. Indirect evidence of breeding in White Sulphur Springs latilong. Occurs in Montana from late May to September. Active nests have been recorded in Montana as late as the end of July (Johnsgard 1986:308, Ellis et al. 1996:86).

Abundance: Common

Diet: Primarily insects and spiders; secondarily fruit (though fruit can sometimes compose $>50 \%$ of diet); young fed almost 100\% insects (Ehrlich et al. 1988:468).

Key Habitat Associations: Riparian associate.

Foraging: Associated with habitats of dense thickets, including riverine forests, prairie coulees, city parks and suburbs, orchards, woodland edges, shrubby marsh borders, aspen groves, and overgrown areas. Coniferous forests are avoided (Johnsgard 1986:308). In Wyoming, occurs in thick stands of chokecherry, dogwood, and willow along streams. Also found in hedgerows in cropland. Absent from xeric upland shrub habitat (Wyoming Bioinformation Node's Species Atlas 1999). Associated patch features (for southeastern Idaho) are willow subcanopies and large patch size (Saab 1999).

Breeding: Nest is bulky and often in a dense thicket (Ehrlich et al. 1988:468).

Elevation: 900-2,550 m (Wyoming Bioinformation Node's Species Atlas 1999).

\section{Sage Thrasher (Oreoscoptes montanus)}

Occurrence: Summer resident in Livingston latilong; indirect evidence of breeding was recorded prior to 1991. Summer resident in Bozeman and Yellowstone latilongs; breeding confirmed prior to 1991. Indirect evidence of breeding in White Sulphur Springs and Columbus latilongs. Occurs in Wyoming from late March to early October. Wyoming egg records are from 17 May to mid-July (Johnsgard 1986:310, Ellis et al. 1996:86).

\section{Abundance: Uncommon}

Diet: Primarily insects; some berries (Ehrlich et al. 1988:470). 
Key Habitat Associations: Limited use of riparian habitats. Considered sagebrush obligate (Montana Partners In Flight 2000).

Foraging: Closely associated with sage-dominated grasslands and, much less so, with other shrublands dominated by shrubs of similar growth-forms such as rabbitbrush and greasewood (Johnsgard 1986:310). In Wyoming, typical habitats are basin-prairie and mountain-foothills shrubland, with tall sagebrush and greasewood. Dry-land crops and short grass prairie habitats are also used. Juniper is a marginal habitat. Primary vegetation cover types in Wyoming are Wyoming big sagebrush, desert shrub, and mountain big sagebrush (Wyoming Bioinformation Node's Species Atlas 1999).

Breeding: Nest is concealed in or occasionally beneath sagebrush (Ehrlich et al. 1988:470).

Elevation: $900-3,000 \mathrm{~m}$. Most commonly found below 2,400 m, though they have been known to range up to 3,800 $\mathrm{m}$ in Colorado (Wyoming Bioinformation Node's Species Atlas 1999).

Comments: Designated as a species of interest by the Technical Advisory Committee to the Upper Yellowstone River Task Force.

\section{Cedar Waxwing (Bombycilla cedrorum)}

Occurrence: Year-round resident in Livingston latilong; breeding confirmed. Direct evidence of breeding has been recorded for QLL A and B; there is a transient/migrant record for C. Year-round resident in Bozeman latilong and summer resident in White Sulphur Springs latilong; breeding confirmed prior to 1991. Indirect evidence of breeding in Yellowstone and Columbus latilongs. Occurs in Wyoming from early May to November. Montana egg records are from 11 June to 19 August (Johnsgard 1986:315, Ellis et al. 1996:88).

\section{Abundance: Common}

Diet: Primarily fleshy fruits (approximately 70\%); secondarily insects, taken by fly-catching or gleaning from vegetation. Young fed insects initially; berries after a few days (Ehrlich et al. 1988:484, Witmer et al. 1997).

Key Habitat Associations: Riparian associate.

Foraging: Highly associated year-round with fruiting shrubs and trees. Habitats include open woodlands (deciduous, coniferous, and mixed), old-fields, and riparian areas. Forest interiors are avoided. In winter, habitats with junipers are frequently used (Witmer et al. 1997). Occurs in non-natural environments, including farmsteads, parks, and shelterbelts (Johnsgard 1986:315). In Montana, relatively restricted to riparian vegetation types (Hutto and Young 1999). In Wyoming, found in open aspen stands but not mountainous aspen stands (Wyoming Bioinformation Node's Species Atlas 1999). Associated patch features (for southeastern Idaho) are open canopies, willow subcanopies, and litter ground cover (Saab 1999). In cottonwood riparian habitats of Montana, strongly associated with understory (Scott et al., in review). Foraging microhabitat guild is foliage gleaner in middle and upper canopy (Skagen et al. 1998).

Breeding: Often nests in riparian areas that have short, dense trees that provide cover for nests, fruitbearing shrubs and trees, and emerging aquatic insects. Nest is bulky (Witmer et al. 1997).

Elevation: $900-3,000 \mathrm{~m}$. Up to 2,135 $\mathrm{m}$ in Yellowstone (Wyoming Bioinformation Node's Species Atlas 1999).

Comments: A relatively late breeder, with peak activity from mid-June to early September (Witmer et al. 1997). 


\section{Orange-crowned Warbler (Vermivora celata)}

Occurrence: Summer resident in Livingston latilong; direct evidence of breeding has been recorded for QLL B. Summer resident in Yellowstone latilong; breeding confirmed. Indirect evidence of breeding in Yellowstone, White Sulphur Springs, and Columbus latilongs. Occurs in Montana from early May to late September or early October. Active nests have been recorded in Montana as late as 17 August (Johnsgard 1986:325, Ellis et al. 1996:91).

\section{Abundance: Uncommon}

Diet: Primarily invertebrates; secondarily, berries, fruit, nectar, and sap (Ehrlich et al. 1988:504, Sogge et al. 1994).

Key Habitat Associations: Occasional use of riparian habitats.

Foraging: Associated with a variety of woodland and brushy habitats, including riparian woodlands, pinyon-juniper habitats, and aspen groves. In montane areas, commonly uses willow or alder thickets near streams, or willow thickets at treeline. At lower elevations, occurs in riverine woods or in brushy vegetation near beaver ponds in northern coniferous woodlands. Brushy areas are also used during migration (Johnsgard 1986:325). In Colorado, uses burns, cutover areas, clearings, thickets, woodland edge, and overgrown pastures (Wyoming Bioinformation Node's Species Atlas 1999). More common in valley bottoms than on slopes or ridges. Typically, ground is partly shaded (Sogge et al. 1994, Wyoming Bioinformation Node's Species Atlas 1999). Foraging microhabitat guild is foliage gleaner in lower canopy and shrub layer (Skagen et al. 1998).

Breeding: Nest is well-concealed and may occur in a variety of locations: on or near ground, in small crevices or depression in ground or rock, along shady hillsides, on slopes or steep banks, in shrubby bushes, ferns, vines, and trees. Nest is usually sheltered by overhanging vegetation (Sogge et al. 1994).

Elevation: $900-2,700 \mathrm{~m}$. Up to 2,400 $\mathrm{m}$ in Yellowstone; in hills during summer and lower elevations in winter (Wyoming Bioinformation Node's Species Atlas 1999).

Comments: At high risk of extinction in the Greater Yellowstone Ecosystem (Hansen et al. 1999). Easily overlooked due to weak song and drab plumage (Johnsgard 1986:325).

\section{Yellow Warbler (Dendroica petechia)}

Occurrence: Summer resident in Livingston latilong; breeding confirmed. Indirect evidence of breeding has been recorded for QLL A and D; direct evidence for B and C. Summer resident in Bozeman, Yellowstone, White Sulphur Springs, and Columbus latilongs; breeding confirmed. Occurs in Montana from second week of May to mid-September. Colorado egg records are from 18 June to 6 July (Johnsgard 1986:329, Ellis et al. 1996:91).

Abundance: Abundant

Diet: Insects; few berries (Ehrlich et al. 1988:532).

Key Habitat Associations: Riparian obligate. 


\begin{abstract}
Foraging: Associated with moist habitats, including riparian woodlands and brush, brushy edges of marshes, swamps, or beaver ponds; also drier areas, including roadside thickets, hedgerows, orchards, and forest edges. The combination of open areas and dense shrubbery seems to be an important factor for breeding (Johnsgard 1986:329). In Montana, considered a riparian obligate (Hutto and Young 1999). In Wyoming, associated with willow and Russian olive. Not associated with grasslands or xeric upland shrub unless near water (Wyoming Bioinformation Node's Species Atlas 1999). Associated patch and landscape-level features (for southeastern Idaho) are dense shrub layers, agricultural landscapes, landscape heterogeneity, small patch size, and areas in which cottonwood patches are distant from each other (Saab 1999). In cottonwood riparian habitats of Montana, strongly associated with understory (Scott et al., in review). Foraging microhabitat guild is foliage gleaner in middle and upper canopy (Skagen et al. 1998).
\end{abstract}

Breeding: Nest is primarily in shrubs; secondarily, trees (Ehrlich et al. 1988:532).

Elevation: 900-2,400 m (Wyoming Bioinformation Node's Species Atlas 1999).

\title{
Yellow-rumped Warbler (Dendroica coronata)
}

Occurrence: Year-round resident in Livingston latilong; breeding confirmed. Indirect evidence of breeding has been recorded for QLL A and D; direct evidence for B and C. Year-round resident in Bozeman latilong; breeding confirmed prior to 1991. Summer resident in Yellowstone, White Sulphur Springs, and Columbus latilongs; breeding confirmed. Occurs in Montana from late April to early October. Overwintering is suspected in Livingston latilong (Johnsgard 1986:333, Ellis et al. 1996:93).

\section{Abundance: Abundant}

Diet: Primarily insects; secondarily, berries (Ehrlich et al. 1988:518).

Key Habitat Associations: Occasional use of riparian habitats, especially during migration.

Foraging: Highly associated with coniferous forests, including forest riparian. During breeding season, occurs from ponderosa pine zone to timberline (Johnsgard 1986:333). In Yellowstone, found in foothills and montane riparian, aspen and aspen-willow, limber pine-juniper, Douglas fir, lodgepole pine, fir-whitebark pine, and spruce-fir. Not found in mountain sagebrush in Wyoming. During migration, occurs in coniferous forests, mountain meadows, aspen groves, agricultural and urban areas, and riparian lowlands (Wyoming Bioinformation Node's Species Atlas 1999). Associated patch and landscape-level features (for southeastern Idaho) are natural (non-agricultural) landscapes and large patch size (Saab 1999). Foraging microhabitat guild is foliage gleaner in middle and upper canopy (Skagen et al. 1998).

Breeding: Nest is in a coniferous tree, from 1-15 m above ground (Ehrlich et al. 1988:518).

Elevation: $900-3,150 \mathrm{~m}$. Found up to tree line during breeding season; lower elevations in migration (Wyoming Bioinformation Node's Species Atlas 1999).

Comments: Forages from lowest branches to highest crown levels (Johnsgard 1986:333).

\section{American Redstart (Setophaga ruticilla)}

Occurrence: Summer resident in Livingston latilong; breeding confirmed. Direct evidence of breeding has been recorded for QLL A; there is a transient/migrant record for B. Summer resident in Bozeman, Yellowstone, and Columbus latilongs; breeding confirmed. Indirect evidence of breeding in White Sulphur 
Springs latilong. Occurs in Montana from mid-May to latter half of September. In Montana, active nests have been reported from 5 June to 30 June (Johnsgard 1986:343, Ellis et al. 1996:96).

\section{Abundance: Uncommon}

Diet: Insects; rarely seeds and berries (Ehrlich et al. 1988:548).

Key Habitat Associations: Riparian obligate.

Foraging: Associated with wooded habitats, including moist bottomland woodlands, margins or openings of mature forests, young or second-growth stands of various types of forests, and especially deciduous forests. Nearby water and a brush layer seem to be important habitat features (Johnsgard 1986:343). In western North America, found most frequently in willow and alder thickets, riparian woodlands, and coniferous woodlands (Sherry and Holmes 1997). In Montana, considered a riparian obligate (Hutto and Young 1999). In Colorado, found in the three habitats mentioned above, plus residential areas, grasslands with trees, mountain shrubs, and forests containing aspen, cottonwood, lodgepole pine, ponderosa pine, Douglas fir, and juniper (Wyoming Bioinformation Node's Species Atlas 1999). In cottonwood riparian habitats of Montana, strongly associated with understory (Scott et al., in review).

Breeding: Nest is often in fork of low tree, from 3-6.5 m above ground; also may be in shrub; rarely on ground (Ehrlich et al. 1988:548). In western North America, nest is often in vegetation near or over water. Nest is generally near central trunk (Sherry and Holmes 1997).

Elevation: 900-3,000 m (Wyoming Bioinformation Node's Species Atlas 1999).

Comments: Study site is in a narrow band of breeding range. Relatively short breeding season, peaking between the end of May and first week of July (Sherry and Holmes 1997). At high risk of extinction in the Greater Yellowstone Ecosystem (Hansen et al. 1999).

\section{Ovenbird (Seiurus aurocapillus)}

Occurrence: Summer resident in Livingston latilong; indirect evidence of breeding was recorded prior to 1991. Summer resident in Bozeman, White Sulphur Springs, and Columbus latilongs evidence of breeding indirect. No record for Yellowstone latilong. Occurs in Montana from second or third week of May to latter half of September. In Montana, nesting has been recorded in June and young observed in July (Johnsgard 1986:346, Ellis et al. 1996:97).

Abundance: Rare

Diet: Insects, worms, spiders, and snails (Ehrlich et al. 1988:542).

Key Habitat Associations: Riparian associate.

Foraging: Associated with deciduous forests or mixed forests composed chiefly of deciduous trees. In Montana, primarily occurs in riparian cottonwood/aspen stands (Hutto and Young 1999). Requires a large area of contiguous, interior forested habitat (100-885 ha minimum). Important parameters are a canopy height of 16-22 m and a canopy closure of 60-90\%. Habitats must be humid enough to sustain invertebrate food supplies in the leaf litter (Van Horn and Donovan 1994). Found on northfacing slopes and shady ravines (presumably for humid conditions). In Alberta, associated with woods with less than dense undergrowth for ground foraging (Johnsgard 1986:346). In Wyoming, occurs in canyons and gulches among relatively dense stands of aspen and of birch where birch merges with pine 
or spruce; less frequent in cottonwoods, elders, and other riparian trees at lower elevations. During migration, uses prairie trees, shrubland, and farmland (Wyoming Bioinformation Node's Species Atlas 1999).

Breeding: Nest is on ground in woodlands with sparse understory and placed on a thick leaf layer. Nest may be in the open or beneath herbaceous vegetation or at base of bush, tree, or log. Nest is domed and well-camouflaged (Van Horn and Donovan 1994).

Elevation: 900-3,000 m (Wyoming Bioinformation Node's Species Atlas 1999).

Comments: Study site is on western edge of breeding range and migratory pathway (Van Horn and Donovan 1994, National Geographic Society 1999:386).

\section{Northern Waterthrush (Seiurus noveboracensis)}

Occurrence: Summer resident in Livingston latilong; indirect evidence of breeding has been recorded for QLL A. Summer resident in Bozeman latilong; breeding confirmed prior to 1991. Migrant in Yellowstone latilong. Summer resident in White Sulphur Springs latilong; breeding confirmed. Indirect evidence of breeding in Columbus latilong. Occurs in Montana from mid-May to late September. No egg records for Montana, Wyoming, or Colorado (Johnsgard 1986:347, Ellis et al. 1996:97).

Abundance: Uncommon

Diet: Aquatic and terrestrial insects, mollusks, crustaceans, and occasionally small fish (Ehrlich et al. 1988:544).

Key Habitat Associations: Riparian obligate.

Foraging: Associated with northern woodlands near ponds, lakes, and streams, especially those with brushy bogs and swampy areas of forest. Found in habitats with standing water more so than in those with running water (Johnsgard 1986:347). Two most important habitat requirements appear to be dense cover near ground level and presence of water (Eaton 1995). In Wyoming, probably limited to riparian and wetland areas. Migrates through riparian lowlands, agricultural lands (orchards), urban areas, marshes, bogs, and wet hummocks. Primary vegetation cover types in Wyoming are unclassified riparian, forest-dominated riparian, and shrub-dominated riparian (Wyoming Bioinformation Node's Species Atlas 1999). Foraging microhabitat guild is gleaner in forb layer, ground, and litter (Skagen et al. 1998).

Breeding: Nest is usually hidden in roots of uprooted tree or under overhanging bank, close to water (Ehrlich et al. 1988:544).

Elevation: $900-3,000 \mathrm{~m}$; up to $2,400 \mathrm{~m}$ in Yellowstone (Wyoming Bioinformation Node's Species Atlas 1999).

Comments: Study site touches southern tip of breeding range (Eaton 1995, National Geographic Society 1999:386). Spends much time walking on ground, along water's edge, and wading; feeding behavior is similar to that of a small sandpiper (Ehrlich et al. 1988:544). At high risk of extinction in the Greater Yellowstone Ecosystem (Hansen et al. 1999).

\section{MacGillivray's Warbler (Oporornis tolmiei)}

Occurrence: Summer resident in Livingston latilong; breeding confirmed. Indirect evidence of breeding has been recorded for QLL A and D; direct evidence for C. Summer resident in Bozeman, White Sulphur 
Springs, and Yellowstone latilongs; breeding confirmed prior to 1991. Indirect evidence of breeding in Columbus latilong. Occurs in Wyoming from 7 May to 13 October (Johnsgard 1986:348, Ellis et al. 1996:98).

\section{Abundance: Common}

Diet: Insects, including true bugs, leaf hoppers, beetles, weevils, caterpillars, bees, wasps, and ants (Pitocchelli 1995).

Key Habitat Associations: Riparian associate.

Foraging: Associated with dense undergrowth and moderate cover in riparian habitats. Occurs primarily in coniferous-forest clearcuts of spruce and Douglas fir or mixed deciduous forests with birch, aspen, and poplar (Pitocchelli 1995). In Wyoming, occurs especially in riparian woodlands with dense undergrowth and less often in woodlands on upland slopes or in river bottoms. In migration, uses riparian, shrub, urban, pine-juniper, agricultural land, grasslands, big sage, and wetlands (Wyoming Bioinformation Node's Species Atlas 1999). Associated patch landscape-level features (for southeastern Idaho) are dense shrub layers and natural (non-agricultural) landscapes (Saab 1999). Foraging microhabitat guild is foliage gleaner in lower canopy and shrub layer (Skagen et al. 1998).

Breeding: Nests along river and stream banks. Nest is always concealed in dense undergrowth. Mean height of nest is $46.3 \mathrm{~cm}$; extremes are ground level to $274.3 \mathrm{~cm}$ above ground (Pitocchelli 1995).

Elevation: 900-2,700 m (Wyoming Bioinformation Node's Species Atlas 1999).

Comments: Designated as a species of interest by the Technical Advisory Committee to the Upper Yellowstone River Task Force. At high risk of extinction in the Greater Yellowstone Ecosystem (Hansen et al. 1999).

\section{Common Yellowthroat (Geothlypis trichas)}

Occurrence: Summer resident in Livingston latilong; breeding confirmed. Indirect evidence of breeding has been recorded for QLL A; there is a transient/migrant record for B; direct evidence for C. Summer resident in Bozeman, White Sulphur Springs, and Yellowstone latilongs; breeding confirmed prior to 1991. Indirect evidence of breeding in Columbus latilong. Occurs in Montana from mid-May to mid- or late September. In Montana, active nests have been reported from 28 May to 29 June (Johnsgard 1986:349, Ellis et al. 1996:98).

\section{Abundance: Common}

Diet: Insects and spiders; few seeds (Ehrlich et al. 1988:546).

Key Habitat Associations: Riparian obligate, except during migration.

Foraging: Found in moist to wet habitats, with tall grasses, shrubs, and small trees (Johnsgard 1986:349). In Wyoming, found in thickets of willow, bog birch, gooseberry, and raspberry, often near open wet ground with sedges, rushes, and other tall herbaceous plants. Uses urban areas, forest edges, and shrubs in migration. Primary vegetation cover types in Wyoming are forest-dominated riparian and shrub-dominated riparian (Wyoming Bioinformation Node's Species Atlas 1999). In cottonwood riparian habitats of Montana, strongly associated with understory (Scott et al., in review). Foraging microhabitat guild is foliage gleaner in lower canopy and shrub layer (Skagen et al. 1998).

Breeding: Nest is in a shrub, from 0-1 $\mathrm{m}$ above ground (Ehrlich et al. 1988:546). 
Elevation: 900-2,400 m (Wyoming Bioinformation Node's Species Atlas 1999).

Comments: Possibly the most abundant warbler, and one of the three most frequent cowbird hosts (Ehrlich et al. 1988:546). At high risk of extinction in the Greater Yellowstone Ecosystem (Hansen et al. 1999).

\section{Wilson's Warbler (Wilsonia pusilla)}

Occurrence: Summer resident in Livingston latilong. There are transient/migrant records for QLL A and B; indirect evidence of breeding has been recorded for $\mathrm{C}$. Summer resident in Yellowstone latilong; breeding confirmed. Indirect evidence of breeding in Bozeman and in Columbus latilongs. Transient records in White Sulphur Springs latilong. Occurs in Montana from mid-May to late September or early October. Montana egg records are from 6 June to 27 June (Johnsgard 1986:351, Ellis et al. 1996:98).

\section{Abundance: Uncommon}

Diet: Insects; occasionally berries (Ehrlich et al. 1988:538).

Key Habitat Associations: Riparian obligate.

Foraging: Associated with densely vegetated and well-watered habitats, including willow and alder thickets along rivers or beaver ponds, brushy edges of lakeshores, edges of mountain meadows, timberline areas of low shrubby vegetation, and aspen thickets (Johnsgard 1986:351). In Montana, relatively common in riparian areas within high-elevation conifer forests (Hutto and Young 1999). In Colorado, found in willow-grown valleys, mountain streams, and lakes. In migration, uses thickets, shrubs, parks, gardens, agricultural lands, urban areas, and trees in grassland (Wyoming Bioinformation Node's Species Atlas 1999). Foraging microhabitat guild is foliage gleaner in lower canopy and shrub layer (Skagen et al. 1998).

Breeding: At high elevations, nest is on the ground (Ehrlich et al. 1988:538). Nests in thickets and saplings, near streams and ponds (Wyoming Bioinformation Node's Species Atlas 1999).

Elevation: Up to 2,400 m in Yellowstone area (Wyoming Bioinformation Node's Species Atlas 1999).

Comments: Study site is on eastern edge of breeding range (National Geographic Society 1999:384). At high risk of extinction in the Greater Yellowstone Ecosystem (Hansen et al. 1999).

\section{Yellow-breasted Chat (Icteria virens)}

Occurrence: Summer resident in Livingston latilong; indirect evidence of breeding was recorded prior to 1991. Indirect evidence of breeding in Bozeman, White Sulphur Springs, and Columbus latilongs. No record for Yellowstone latilong. Occurs in Montana from 10 May to early September. Montana egg records are from 11 June to 23 July (Johnsgard 1986:353, Ellis et al. 1996:99).

\section{Abundance: Common}

Diet: Insects and berries about equally (Ehrlich et al. 1988:548).

Key Habitat Associations: Riparian associate.

Foraging: Associated with shrubby habitats, including alder-and willow-lined prairie creeks, oak and mountain mahogany woodlands, brushy forest edges, overgrown pasturelands, and shrubby coulee 
areas of the plains (Johnsgard 1986:353). In Wyoming, uses streamside thickets, especially where willow is dominant, and uses dense brush in draws and hollows. In Colorado, uses urban and agricultural areas during migration. Habitats are similar to those used by catbirds (Wyoming Bioinformation Node's Species Atlas 1999). Associated patch and landscape-level features (for southeastern Idaho) are herbaceous ground cover, dense shrub layers, and areas in which cottonwood patches are near each other (Saab 1999). In cottonwood riparian habitats of Montana, strongly associated with understory (Scott et al., in review). Foraging microhabitat guild is foliage gleaner in lower canopy and shrub layer (Skagen et al. 1998).

Breeding: Nest is in shrubs, from $.3-1.5 \mathrm{~m}$ above ground. Nest is large but well concealed (Ehrlich et al. 1988:548).

Elevation: 900-2,400 m (Wyoming Bioinformation Node's Species Atlas 1999).

\section{Western Tanager (Piranga ludoviciana)}

Occurrence: Summer resident in Livingston latilong, breeding confirmed. Occurs in all four QQL. Breeding confirmed in Bozeman, Yellowstone, and Columbus latilongs. Indirect evidence of breeding in White Sulphur Springs latilong (Johnsgard 1986:356, Ellis et al. 1996:100).

Abundance: Common

Diet: Mainly insects, some fruit. Relies on diet for external source of rhodoxanthin, a rare plumage pigment (Hudon 1999).

Key Habitat Associations: Occasional use of riparian habitats.

Foraging: Associated primarily with pine forests; secondarily deciduous woods along streams and in gulches and canyons. Breeds in riparian woodlands, aspen groves, ponderosa pine, occasionally Douglas fir, pine-juniper or oak-mountain mahogany (Johnsgard 1986). Colorado sources: most riparian habitats and open areas, edges (Wyoming Bioinformation Node's Species Atlas 1999).

Breeding: Prefers forests with open canopies, meadow edges. Loosely woven open bowl nest primarily placed in conifer trees but also some in deciduous trees generally 2-20 m from ground (Hudon 1999).

Elevation: Up to $2,400 \mathrm{~m}$ in Yellowstone.

\section{Green-tailed Towhee (Pipilo chlorurus)}

Occurrence: Summer resident in Livingston latilong, breeding confirmed. Direct evidence of breeding in QQL $C$ and indirect evidence of breeding in QQL A, B, and D. Summer resident in Bozeman, Yellowstone, White Sulphur Springs, and Columbus latilongs; breeding confirmed (Johnsgard 1986:363, Ellis et al. 1996:102).

\section{Abundance: Common}

Diet: Seeds, small insects, some fruit.

Key Habitat Associations: Occasional use of riparian habitats, especially during migration.

Foraging: Brushy foothills dominated by sagebrush, scrub oaks, saltbush and greasewood flats. Second growth after disturbances; low brush cover with very scattered trees (Montana Partners In Flight 
2000). Riparian woodlands in semi-arid areas. Forested areas are avoided, but scattered trees are used as singing posts (Johnsgard 1986). Colorado sources: most commonly associated with scrub oak mountain mahogany and sagebrush of the transition zone; also open stands of pine-juniper and ponderosa pine- Douglas fir (Wyoming Bioinformation Node's Species Atlas 1999).

Breeding: Dry shrubby hillsides, post-disturbance shrubby growth; mixed species shrub communities (Dobbs et al. 1998). Nests are bulky, thick-walled and well concealed in dense shrubs (Dobbs et al. 1998, Montana Partners in Flight 2000).

Elevation: $1,200-3,450 \mathrm{~m}$. Breeding is primarily restricted to below $2,700 \mathrm{~m}$; after the nesting season they may wander up to alpine areas (Wyoming Bioinformation Node's Species Atlas 1999).

Comments: Common migrant on the plains.

\section{Spotted Towhee (Pipilo maculatus)}

Occurrence: Summer resident in Livingston latilong, breeding confirmed. Direct evidence of breeding in QQL B and indirect evidence of breeding in QQL A. Summer resident in Bozeman, Yellowstone, and Columbus latilongs. Indirect evidence of breeding in White Sulphur Springs latilongs (Johnsgard 1986:364, Ellis et al. 1996:102).

\section{Abundance: Abundant}

Diet: Primarily terrestrial arthropods including beetles and grasshoppers during the breeding season. Seeds and fruits more common in diet during non-breeding season.

Key Habitat Associations: Occasional use of riparian.

Foraging: Breeding is in brushy fields, thickets, woodland openings or edges, second-growth forests, city parks, and suburbs (Johnsgard 1986). Dry deciduous thickets along streams or on adjacent lower slopes in hollows, gulches; open pine woods with brushy understory; burned areas with secondary growth of shrubs and aspens (Wyoming Bioinformation Node's Species Atlas 1999).

Breeding: Preference for dense nesting cover. Nests on ground or up to $3.6 \mathrm{~m}$ above ground. May nest in riparian areas on prairies and in foothills (Greenlaw 1996).

Elevation: $900-2,400 \mathrm{~m}$.

Comments: At high risk of extinction in the Greater Yellowstone Ecosystem (Hansen et al. 1999).

\section{Chipping Sparrow (Spizella passerina)}

Occurrence: Summer resident in Livingston latilong, breeding confirmed. Direct evidence of breeding in QQL C, and indirect evidence of breeding in QQL A and D. Breeding confirmed in Bozeman, White Sulphur Springs, Yellowstone, and Columbus latilongs (Johnsgard 1986:367, Ellis et al. 1996:103).

Abundance: Abundant

Diet: Seeds of grass and forbs throughout the year and insects during the breeding season.

Key Habitat Associations: Occasional use of riparian habitats. 
Foraging: Breeds in open deciduous or mixed forests, forest margins, timberline scrub, riparian woodlands, pine-juniper or oak-mountain mahogany woodlands. Sparse ground covering and unshaded forest floor are important in general (Johnsgard 1986). Transient though fields, brushy areas, and roadsides. In Yellowstone, uses riparian habitat, juniper-sagebrush, limber pine-juniper, aspen, and aspen willow, Douglas fir, lodgepole pine, and willow thickets (Wyoming Bioinformation Node's Species Atlas 1999).

Breeding: Prefers shrubby coniferous habitats bordering open grassy spaces, aspen groves, river and lake shorelines. Loosely woven cup nest 1-3 m above ground, usually in conifers (Middleton 1998). Elevation: $900-3,000 \mathrm{~m}$.

Comments: Now more common in suburban areas and around rural residences and farms than in undisturbed habitats (Middleton 1998).

\section{Brewer's Sparrow (Spizella breweri)}

Occurrence: Summer resident in Livingston latilong; breeding confirmed. Indirect evidence of breeding has been recorded for QLL A; direct evidence for C. Summer resident in Bozeman, Yellowstone, and White Sulphur Springs latilongs; breeding confirmed prior to 1991. Indirect evidence of breeding in Columbus latilongs. Occurs in Montana from early May to late September. Montana egg records are from 24 May to 16 June, with nestlings observed into late July (Johnsgard 1986:369, Ellis et al. 1996:103).

Abundance: Common

Diet: Primarily insects, including few spiders; secondarily seeds of forbs and grasses (Ehrlich et al. 1988:588).

Key Habitat Associations: Limited use of riparian habitats.

Foraging: Associated with dry habitats, including shortgrass prairies with sage or other semi-arid shrubs present, mountain mahogany and currant bushes along hillsides, mesa edges, sagebrush flats, serviceberry-covered slopes of mountain ridges, and stunted spruces, firs, willows, and alders near timberline (Johnsgard 1986:369). Throughout most of the U.S. range, most closely associated with landscapes dominated by big sagebrush (Artemisia tridentata), where it is usually the most abundant bird species (Rotenberry et al. 1999). In Montana, found commonly in silver sage and sagebrush grassland. Primary vegetation cover types in Wyoming are Wyoming big sagebrush, mixed grass prairie, mountain big sagebrush, and desert shrub (Wyoming Bioinformation Node's Species Atlas 1999). Foraging microhabitat guild is gleaner in forb layer, ground, and litter (Skagen et al. 1998).

Breeding: Nest is in shrub or low tree, from 0-1.3 m above ground (Ehrlich et al. 1988:588). Nest shrubs are usually alive or mostly alive, the foliage of which provides concealment from predators and protection from elements (Rotenberry et al. 1999).

Elevation: Range $900-3,000 \mathrm{~m}$; up to 2,073 $\mathrm{m}$ in Yellowstone (Wyoming Bioinformation Node's Species Atlas 1999).

Comments: At high risk of extinction in the Greater Yellowstone Ecosystem (Hansen et al. 1999).

\section{Fox Sparrow (Passerella iliaca)}

Occurrence: Year-round resident in Livingston latilong; indirect evidence of breeding has been recorded for QLL A. Summer resident in Yellowstone latilong; breeding confirmed. Indirect evidence of breeding in 
Bozeman and White Sulphur Springs latilongs No record for Columbus latilong. Occurs in Montana from early April to mid-October. Colorado egg records are from 8-28 June (Johnsgard 1986:380, Ellis et al. 1996:106).

Abundance: Uncommon

Diet: Primarily insects, including a few spiders and millipedes; secondarily seeds, berries, and buds (Ehrlich et al. 1988:596).

Key Habitat Associations: Riparian associate.

Foraging: Associated with dense, brushy habitats, including the brushy margins of thick forests, riparian thickets of willows or alders, alder clumps on mountain slopes, and twisted and stunted conifers near timberline. Requires space underneath thickets for ground foraging, with a mat of leaves and litter for scratching towhee-like (Johnsgard 1986:380). In Wyoming, found in riparian shrub with adjacent coniferous forest or woodland-chaparral. Primary vegetation cover types in Wyoming are aspen groves and forest-dominated riparian (Wyoming Bioinformation Node's Species Atlas 1999). Associated patch and landscape-level features (for southeastern Idaho) are litter ground cover and natural (non-agricultural) landscapes (Saab 1999).

Breeding: Nest is on ground or in low shrub (typically below $1 \mathrm{~m}$ ), and rarely in trees (Ehrlich et al. 1988:596).

Elevation: $900-3,000 \mathrm{~m}$; up to $1,890 \mathrm{~m}$ in Yellowstone (Wyoming Bioinformation Node's Species Atlas 1999).

\section{Song Sparrow (Melospiza melodia)}

Occurrence: Year-round resident in Livingston latilong; breeding confirmed. Indirect evidence of breeding has been recorded for QLL A; direct evidence for C. Year-round resident in Bozeman latilong and summer resident in Columbus latilong; evidence of breeding indirect. Year-round resident in Yellowstone latilong and summer resident in White Sulphur Springs latilong; breeding confirmed. Montana egg records are from 1-22 June (Johnsgard 1986:381, Ellis et al. 1996:107).

\section{Abundance: Common}

Diet: Primarily insects; also seeds of grasses and forbs; some berries (Ehrlich et al. 1988:576).

Key Habitat Associations: Riparian obligate.

Foraging: Associated with woodland edge habitats, including brushy margins of forest openings, edges of ponds or lakes, shelterbelts, farmsteads, coulees on prairies, and aspen groves. Forages mostly on ground, both in open and leaf-covered areas (Johnsgard 1986:381). In Montana, relatively restricted to streamsides, bottomlands, and marshlands (Hutto and Young 1999). In Wyoming, associated with aspen groves of large, well-spaced trees with moderate shrub cover and nearby surface water. Found in brushy edges of marshes and streamside thickets at all elevations (Wyoming Bioinformation Node's Species Atlas 1999). Associated patch and landscape-level features (for southeastern Idaho) are open canopies, willow subcanopies, natural (non-agricultural) landscapes, heterogeneous landscapes, small patch size, and areas in which cottonwood patches are distant from each other (Saab 1999). In cottonwood riparian habitats of Montana, strongly associated with understory (Scott et al., in review). Foraging microhabitat guild is gleaner in forb layer, ground, and litter (Skagen et al. 1998). 
Breeding: Nest is typically on ground, beneath grass tuft, shrub, or brushpile. If above ground, nest is usually no higher than $1 \mathrm{~m}$ (Ehrlich et al. 1988:576).

Elevation: $900-3,000 \mathrm{~m}$; up to 2,400 $\mathrm{m}$ in Yellowstone (Wyoming Bioinformation Node's Species Atlas 1999).

\section{Lincoln's Sparrow (Melospiza lincolnii)}

Occurrence: Summer resident in Livingston latilong, breeding confirmed. Direct evidence of breeding in QQL C, and indirect evidence of breeding in QQL A and D. Breeding confirmed in Yellowstone latilong. Indirect evidence of breeding in Bozeman, White Sulphur Springs, and Columbus latilongs (Johnsgard 1986:382, Ellis et al. 1996:107).

Abundance: Common

Diet: Grass and forb seeds, spiders and millipedes.

Key Habitat Associations: Riparian obligate.

Foraging: Commonly found in boggy mountain meadows, especially those fringed with willow thickets and supporting a tall growth of grasses, sedges, and herbs (Johnsgard 1986). Riparian thickets, aspen-willow-sedge, spruce-fir; also found in subalpine meadows, in aspen understory not necessarily close to water; but not found in spruce-fir except near water (Wyoming Bioinformation Node's Species Atlas 1999).

Breeding: Is a distinct microsite specialist, preferring low willow cover with dense ground vegetation. Builds nest in wet sites on the ground on elevated mounts (Ammon 1995).

Elevation: $900-3,750 \mathrm{~m}$; found between 2,100-3,600 m during breeding, and lower elevations during migration.

\section{White-crowned Sparrow (Zonotrichia leucophrys)}

Occurrence: Year-round resident in Livingston latilong; breeding confirmed. Indirect evidence of breeding has been recorded for QLL A, B, and D; direct evidence for C. Summer resident in Bozeman, Yellowstone, White Sulphur Springs, and Columbus latilongs breeding confirmed prior to 1991. Occurs in Montana from late April to early or mid-October. Active nests have been recorded in Montana from 24 June to 8 August (Johnsgard 1986:386, Ellis et al. 1996:108).

\section{Abundance: Common}

Diet: Arthropods (mostly insects) and seeds (Chilton et al. 1995).

Key Habitat Associations: Occasional use of riparian habitats.

Foraging: Associated with shrubby habitats, including riparian brush, coniferous forests with welldeveloped wooded undergrowth, aspen groves with shrubby understory, willow thickets around beaver ponds or marshes, mountain meadows with alders or similar low and thick shrubbery, often to timberline (Johnsgard 1986:386). Five necessary habitat features are grass (pure or mixed with other plants), bare ground for foraging, dense shrubs or small conifers for roost and nest concealment, standing or running water on or near territory, and tall coniferous trees (typically located on edge of territory) (Chilton et al. 1995). In Yellowstone, found in willow thickets, fir-whitebark pine, spruce- 
fir, and alpine tundra (Wyoming Bioinformation Node's Species Atlas 1999). Foraging microhabitat guild is gleaner in forb layer, ground, and litter (Skagen et al. 1998).

Breeding: Nest is typically on ground or in a low shrub (Chilton et al. 1995).

Elevation: 1,900-3,000 m (Wyoming Bioinformation Node's Species Atlas 1999).

\section{Black-headed Grosbeak (Pheucticus melanocephalus)}

Occurrence: Summer resident in Livingston latilong; breeding confirmed. Direct evidence of breeding has been recorded for QLL A. Indirect evidence of breeding in Bozeman, Yellowstone, White Sulphur Springs, and Columbus latilongs Occurs in Montana from mid- or late May to late August or early September. Active nests in Montana have been recorded from 5 June to late July. Overwintering is suspected in Livingston latilong (Johnsgard 1986:358, Ellis et al. 1996:101).

\section{Abundance: Common}

Diet: Insects, including snails and spiders; wild and cultivated fruit and grain (Hill 1995).

Key Habitat Associations: Occasional use of riparian habitats.

Foraging: Occurs in diverse habitats, including cottonwood and willow groves, deciduous growth in mountain valleys and canyons, aspen groves, openings in mature pine forests, and pinyon-juniper woodlands. Associated with local diversity of plant growth and edge conditions (Hill 1995). Found in woodlands with well-developed shrubby understories (Johnsgard 1986:358; Wyoming Bioinformation Node's Species Atlas 1999). Associated patch features (for southeastern Idaho) include willow subcanopies (Saab 1999). In cottonwood riparian habitats of Montana, strongly associated with understory (Scott et al., in review). Foraging microhabitat guild is foliage gleaner in middle and upper canopy (Skagen et al. 1998).

Breeding: Nest is typically located in the outer branches of a small deciduous tree or bush, often near a stream, and usually 3-4 $\mathrm{m}$ above ground (Hill 1995).

Elevation: 900-2,400 m (Wyoming Bioinformation Node's Species Atlas 1999).

\section{Lazuli Bunting (Passerina amoena)}

Occurrence: Summer resident in Livingston latilong; breeding confirmed. Indirect evidence of breeding has been recorded for QLL A and D; direct evidence for B and C. Summer resident in Yellowstone and Columbus latilongs breeding confirmed prior to 1991. Indirect evidence of breeding in Bozeman and White Sulphur Springs latilongs. Occurs in Montana from mid-May to early September. Montana egg records are from 1 June to 2 August (Johnsgard 1986:360, Ellis et al. 1996:101).

\section{Abundance: Common}

Diet: Arthropods, including small spiders, caterpillars, butterflies, grasshoppers, beetles, ants, and bugs. Also, berries and seeds (Greene et al. 1996).

Key Habitat Associations: Occasional use of riparian habitats.

Foraging: In the mountains, associated with edges of deciduous forests on gentle valley slopes, including aspen groves and thickets of willow or alder. In the foothills and plains, associated with riparian woodlands supporting a mix of shrubs, low trees, and herbaceous vegetation. Important habitat features 
seem to be high plant diversity and discontinuity of cover (Johnsgard 1986:360). In Wyoming, found in low deciduous thickets along streams and roadsides, in hollows and prairie draws, and occasionally in residential areas. During migration, found in all types of shrubs, riparian and urban areas (Wyoming Bioinformation Node's Species Atlas 1999). Associated patch and landscape-level features (for southeastern Idaho) are herbaceous ground cover, dense shrub layers, willow subcanopies, and homogeneous landscapes (Saab 1999). Foraging microhabitat guild is forest generalist (Skagen et al. 1998).

Breeding: Nest is typically low in a dense, well-shaded bush (Greene et al. 1996).

Elevation: 900-3,000 m (Wyoming Bioinformation Node's Species Atlas 1999; Montana Partners In Flight 2000).

Comments: Priority II species designation (second highest priority, recommendation of monitoring and/or conservation action) by Montana Partners in Flight (2000).

\section{Brown-headed Cowbird (Molothrus ater)}

Occurrence: Summer resident in Livingston latilong; breeding confirmed. Direct evidence of breeding has been recorded for QLL A and C. Summer resident in Bozeman, Yellowstone, White Sulphur Springs, and Columbus latilongs; breeding confirmed prior to 1991. Occurs in Montana from late April or early May to late August (Johnsgard 1986:400, Ellis et al. 1996:112).

Abundance: Abundant

Diet: Primarily insects, spiders, and snails; secondarily grains and seeds of grasses and forbs (Ehrlich et al. 1988:616).

Key Habitat Associations: Occasional use of riparian habitats.

Foraging: Associated with woodland edge habitats, including brushy thickets, forest clearings, brushy creek bottoms in prairies, aspen groves, sagebrush, desert scrub, agricultural lands, and open coniferous forests (Johnsgard 1986:400). In Wyoming, occurs nearly everywhere except in dense forest (Wyoming Bioinformation Node's Species Atlas 1999). Associated patch and landscape-level features (for southeastern Idaho) are dense shrub layers, willow subcanopies, agricultural landscapes, homogeneous landscapes, and small patch size (Saab 1999). In cottonwood riparian habitats of Montana, strongly associated with understory (Scott et al., in review). Foraging microhabitat guild is gleaner in forb layer, ground, and litter (Skagen et al. 1998).

Breeding: Builds no nest, depositing its eggs in nests of other species, especially flycatchers, warblers, finches, and vireos (Ehrlich et al. 1988:616).

Elevation: 900-2,700 m (Wyoming Bioinformation Node's Species Atlas 1999).

\section{Bullock's Oriole (Icterus bullockii)}

Occurrence: Summer resident in Livingston latilong; breeding confirmed. Direct evidence of breeding has been recorded for QLL A. Summer resident in Bozeman, Yellowstone, and Columbus latilongs; breeding confirmed prior to 1991. Indirect evidence of breeding in White Sulphur Springs latilong. Occurs in Montana from 8 May to 8 September. Active nests have been recorded in Montana from 29 May to early July (Johnsgard 1986:402, Ellis et al. 1996:113). 


\section{Abundance: Common}

Diet: Primarily insects, spiders, and snails; secondarily fruit and nectar (Ehrlich et al. 1988:624).

Key Habitat Associations: Riparian associate.

Foraging: Occurs in a variety of habitats, including river bottom forests of willows and cottonwoods, plains or foothills slopes, valleys with aspen, poplars, birches, and similar vegetation, and city parks (Johnsgard 1986:402). Primary vegetation cover types in Wyoming are juniper woodlands, forestdominated riparian, and shrub-dominated riparian (Wyoming Bioinformation Node's Species Atlas 1999). Associated patch and landscape-level features (for southeastern Idaho) are dense shrub layers, agricultural landscapes, homogeneous landscapes, and small patch size (Saab 1999). Foraging microhabitat guild is foliage gleaner in middle and upper canopy (Skagen et al. 1998).

Breeding: Nest is pendulous, typically located in a deciduous tree (rarely coniferous) between 4.5 and $9 \mathrm{~m}$ (Ehrlich et al. 1988:624).

Elevation: 900-3,000 m (Wyoming Bioinformation Node's Species Atlas 1999).

Comments: At high risk of extinction in the Greater Yellowstone Ecosystem (Hansen et al. 1999).

\section{Cassin's Finch (Carpodacus cassinii)}

Occurrence: Year-round resident in Livingston latilong; breeding confirmed. Direct evidence of breeding has been recorded for QLL A and C; indirect evidence for D. Year-round resident in Bozeman and Yellowstone latilongs; breeding confirmed prior to 1991. Indirect evidence of breeding in White Sulphur Springs and Columbus latilongs. No dates of occurrence reported. In Montana, nest-building or incubation activities have been reported from 20 May to 17 July (Johnsgard 1986:406, Ellis et al. 1996:115).

Abundance: Common

Diet: Mostly vegetable matter, particularly buds, berries and other fruits, and seeds; some insects (Hahn 1996).

Key Habitat Associations: Occasional use of riparian habitats.

Foraging: Associated with open coniferous forests, over a broad elevational range. Often found in mature forests of lodgepole pine and ponderosa pine. Also breeds in Jeffrey pine, limber pine, Douglas-fir, Engelmann spruce, and quaking aspen (Hahn 1996). In Wyoming, found in coniferous forests, including burns. Uses urban areas and riparian lowlands during winter. In Colorado, forages in meadows adjacent to coniferous forests in spring and summer. Primary vegetation cover types in Wyoming are lodgepole pine, spruce-fir, and aspen (Wyoming Bioinformation Node's Species Atlas 1999). Associated landscape-level features (for southeastern Idaho) include homogeneous landscapes (Saab 1999).

Breeding: Brief breeding season, peaking from late May to early July. Nest is typically in a conifer, usually near end of a lateral branch or near crown (Hahn 1996).

Elevation: $900-3,150 \mathrm{~m}$; breeding at higher elevations, migrating at lower elevations (Wyoming Bioinformation Node's Species Atlas 1999).

Comments: Study site is on eastern edge of year-round range and near eastern edge of breeding range (National Geographic Society 1999:448). 


\section{Red Crossbill (Loxia curvirostra)}

Occurrence: Summer resident in Livingston latilong; breeding confirmed. Direct evidence of breeding has been recorded for QLL A. Year-round resident in Bozeman and Yellowstone latilongs; breeding confirmed prior to 1991. Indirect evidence of breeding in White Sulphur Springs and Columbus latilongs. Occurs in Montana year-round but migrates from high elevations in winter. Active nests in Montana have been observed from 30 April to 27 July (Johnsgard 1986:408, Ellis et al. 1996:115).

Abundance: Common

Diet: Primarily conifer seeds; secondarily deciduous seeds and buds, spruce buds, forb seeds, insects, and berries (Ehrlich et al. 1988:638, Adkisson 1996).

Key Habitat Associations: Occasional use of riparian habitats.

Foraging: Associated with mature coniferous forests where large cone crops are produced by spruce, hemlock, Douglas fir, and/or pine (Adkisson 1996). In Yellowstone ecosystem, occurs in Douglas fir, lodgepole pine, fir-whitebark pine, and spruce-fir. Presence or absence usually depends on the coniferous cone crop. In years of abundant cone seed crop, "invades" areas in large numbers and stays to breed. In migration, uses cottonwood riparian and urban areas. Primary vegetation cover types in Wyoming are lodgepole pine, ponderosa pine, and spruce-fir (Wyoming Bioinformation Node's Species Atlas 1999).

Breeding: Highly variable breeding season, from late December to early October, determined by conifer seed availability. Nest is well-concealed in a coniferous tree, from 2-20 m above ground (Adkisson 1996). Usually breeds from late winter to early spring. In the Rocky Mountains, may breed in year hatched (Ehrlich et al. 1988:638).

Elevation: $900-3,000 \mathrm{~m}$; up to 2,500 m in Yellowstone (Wyoming Bioinformation Node's Species Atlas 1999).

Comments: Migration may occur at any time of year, with peaks from May to third week of July, October to early December, and late January to third week of February (Adkisson 1996).

\section{American Goldfinch (Carduelis tristis)}

Occurrence: Year-round resident in Livingston latilong; breeding confirmed. Direct evidence of breeding has been recorded for QLL A; indirect evidence for B; there is a transient/migrant record for C. Year-round resident in Bozeman latilong; breeding confirmed prior to 1991. Summer resident in Yellowstone, White Sulphur Springs, and Columbus latilongs; breeding confirmed. Occurs in Montana from May to September or October. Active nests in Montana have been observed from mid-July to early September (Johnsgard 1986:414, Ellis et al. 1996:117).

\section{Abundance: Common}

Diet: Primarily seeds; secondarily insects (Ehrlich et al. 1988:636).

Key Habitat Associations: Riparian associate.

Foraging: Associated with open grazing country where thistles are abundant and cattails are present. Ideal nesting habitats are riparian woodlands near weed-infested fields (Johnsgard 1986:414; Wyoming 
Bioinformation Node's Species Atlas 1999). Associated patch and landscape-level features (for southeastern Idaho) are closed canopies, dense shrub layers, and agricultural landscapes (Saab 1999). In cottonwood riparian habitats of Montana, strongly associated with understory (Scott et al., in review). Foraging microhabitat guild is gleaner in forb layer, ground, and litter (Skagen et al. 1998). Breeding: A relatively late breeder, timed with thistle seed production. Thistle "down" is used in nest construction, and thistle seeds are fed to nestlings (Johnsgard 1986:414). Nest is in a shrub or tree, from 3 to $10 \mathrm{~m}$ above ground (Ehrlich et al. 1988:636).

Elevation: 900-2,400 m (Wyoming Bioinformation Node's Species Atlas 1999).

\section{Amphibians}

\section{Tiger Salamander (Ambystoma tigrinum)}

Occurrence: Specimens have not been collected in Livingston latilong. Specimens have been collected in Bozeman and Columbus latilongs (Thompson 1982). More recently, specimens have not been reported for Livingston or Bozeman latilongs (Montana Natural Resources Information System 2000). Specimens have been recorded for Park and Gallatin Counties. Predicted to occur throughout Livingston, Bozeman (except NW comer), and Columbus latilongs (Redmond et al. 1998).

Abundance and Status: Common in Montana east of the Continental Divide (Flath 1984). Not a "Species of Special Concern" or "watchlisted" by the Montana Natural Heritage Program: global rank G5; state rank S5. Montana Fish, Wildlife and Parks status: nongame wildlife.

Diet: Adults eat metamorphosed salamanders, tadpoles, earthworms, snails, bugs, beetles, larval mayflies, dragonflies, caddisflies, midges, and small vertebrates. Larval salamanders will eat large zooplankton (e.g., water fleas, copepods, larval midges); larger larvae eat almost anything they can catch and swallow.

Key Habitat Associations: Riparian obligate. Water is necessary for breeding and larval development. Occurs in almost any habitat where a body of non-flowing water is available for breeding. Associated with prairie and agricultural habitats. Usually absent where predatory fishes, turtles, bullfrogs, and/or crayfish are present. Adults spend a lot of time underground in burrows made by ground squirrels, badgers, and gophers and tend to emerge only briefly to breed. Adults may be found under objects near water; they move to and from breeding sites at night. Occurs in sewage sedimentation ponds and turbid ponds badly polluted by cattle manure (Hammerson 1999). Spring and late summer migrations (from a few individuals to many thousands) generally occur after a rainstorm and at night; migrations often occur in sagebrush areas and along roads (Koch and Peterson 1995).

Elevation (throughout range): From sea level to $3,660 \mathrm{~m}$.

Comments: Size of home range is unknown, but they probably do not range farther than $3 \mathrm{~km}^{2}$. Most widely distributed of all North American salamanders, from British Columbia to northern Florida (Koch and Peterson 1995).

\section{Boreal (Western) Toad (Bufo boreas)}

Occurrence: Specimens have been collected in Livingston and Bozeman latilongs. Neither specimens nor other evidence were reported for Columbus latilong in 1982 but have been reported since then (Thompson 
1982, Montana Natural Resources Information System 2000). Occurs in western third of Montana (Reichel and Flath 1995). Museum specimens exist for Gallatin and Park Counties. Predicted to occur throughout Livingston, Bozeman, and Columbus (except NE quadrant) latilongs (Redmond et al. 1998).

Abundance and Status: Uncommon and local in western Montana, though formerly common and widespread. Does not currently meet criteria of the Montana Natural Heritage Program's "Species of Special Concern" but is included on a "watchlist," indicating that it may meet the criteria in the near future: global rank G4; state rank S3S4. Montana Fish, Wildlife and Parks status: nongame wildlife.

Diet: Insects, especially ants.

Key Habitat Associations: Riparian obligate. Water is necessary for breeding and tadpole development. Associated with a variety of habitats, including desert streams and springs, grassland, woodland, and mountain meadows. Found in wet meadows, beaver ponds, glacial kettle ponds, and lakes within subalpine forests of lodgepole pine, Englemann spruce, subalpine fir, and aspen. Found near water during the breeding season, May-July, depending on elevation. Adult range expands during summer to include drier, upland habitats. Hibernation takes place in small mammal burrows, under creek banks, or in cavities of dams in beaver ponds (Hammerson 1999). Water chemistry at breeding sites typically has a high pH (>8.0), high conductivity, and high acid-neutralizing capacity; hence, risk of acidification is low (Koch and Peterson 1995).

Elevation (throughout range): $2,600-3,500 \mathrm{~m}$.

Comments: Nocturnal in warm, low-lying areas; diurnal at high elevations and in the north. Home range information is limited. Jones (1999) reported a mean of $46,185 \mathrm{~m}^{2}$, but this study was restricted to one population in Colorado. Declines in distribution and abundance are reported for the western U.S., including Colorado, eastern Wyoming, and eastern Utah (Koch and Peterson 1995, Carey et al., in press).

\section{Western Chorus Frog (Pseudacris triseriata)}

Occurrence: Evidence has been reported for Livingston, Bozeman, and Columbus latilongs (Thompson 1982, Montana Natural Resources Information System 2000). Occurs throughout eastern two-thirds of Montana (Reichel and Flath 1995). Museum specimens exist for Sweetgrass County. Predicted to occur throughout Livingston, Bozeman, and Columbus latilongs (Redmond et al. 1998).

Abundance and Status: Common on the prairies of eastern Montana, with a finger of presence along the Upper Yellowstone River corridor. Not a "Species of Special Concern" or "watchlisted" by the Montana Natural Heritage Program. Montana Fish, Wildlife and Parks status: nongame wildlife. Ubiquitous in the Greater Yellowstone Ecosystem (Koch and Peterson 1995).

Diet: Wide variety of invertebrates, including daddy longlegs, springtails, thrips, ants, centipedes, and worms (Christian 1976, 1982).

Key Habitat Associations: Riparian obligate. Water is necessary for breeding and tadpole development. Associated with a variety of habitats containing moving or still water. Generally found in grassy pools, lakes, and marshes of mountains and prairies. In the mountains, occurs along edges of water and ranges 
into wet meadows. May spend inactive periods in more upland habitats, either in rodent burrows or under wetland vegetation in or near water (Hammerson 1999). Breeds in shallow water with emergent vegetation to which eggs can be attached (Koch and Peterson 1995).

Elevation (throughout range): Sea level to $3,670 \mathrm{~m}$.

Comments: Adults are rarely found farther than $700 \mathrm{~m}$ from water and breeding sites (Hammerson 1999). Not arboreal. Calls from April to as late as early July in higher elevations (Koch and Peterson 1995).

\section{Spotted Frog (Rana pretiosa)}

Occurrence: Specimens have been collected in Livingston and Bozeman latilongs. Neither specimens nor other evidence has been reported for Columbus latilong (Thompson 1982). Occurs throughout western Montana (Reichel and Flath 1995). Museum specimens exist for Gallatin, Park, and Sweetgrass Counties as well as other observations for Gallatin and Park Counties. Predicted to occur in drainages throughout Livingston, Bozeman, and Columbus (except center and NE quadrant) latilongs (Redmond et al. 1998).

Abundance and Status: Most common anuran in western Montana although declines have been reported elsewhere (Reichel and Flath 1995). Not a "Species of Special Concern" or "watchlisted" by the Montana Natural Heritage Program. Montana Fish, Wildlife and Parks status: nongame wildlife. Common to abundant throughout Yellowstone and Grand Teton National Parks but declining in southern and western portions of the range (Koch and Peterson 1995).

Diet: Wide variety of invertebrates, including spiders, ants, beetles, moths, dragonflies, mayflies, caddisflies, snails, mosquitoes, worms, grasshoppers, and crickets (Koch and Peterson 1995).

Key Habitat Associations: Riparian obligate. Water is necessary for breeding and tadpole development. Highly aquatic amphibian. Usually occurs near cool, generally permanent water such as springs, pools, rivers, and streams. Highly associated with ponds and quiet waters in mixed coniferous and subalpine forests, and with wetlands near treeline. Also found in grasslands and brushlands. May move considerable distances from water after breeding (Stebbins 1985). In Montana, not found far from open water (Reichel and Flath 1995).

Elevation (throughout range): Sea level to $3,050 \mathrm{~m}$.

Comments: Adults are found in association with some water although they may spend some time in upland habitats. May move frequently, especially at certain times of the year, making it impractical to determine a home range (Koch and Peterson 1995).

\section{Reptiles}

\section{Sagebrush Lizard (Sceloporus graciosus)}

Occurrence: Specimens have been collected in Livingston and Columbus latilongs. Neither specimens nor other evidence has been reported in Bozeman latilong (Thompson 1982, Montana Natural Resources 
Information System 2000). Museum specimens exist for Park County. Predicted to occur in Livingston and Columbus latilongs in areas along Yellowstone River (Redmond et al. 1998). Known to occur along the Yellowstone River near Gardiner (Koch and Peterson 1995).

Abundance and Status: Common locally along the southern border of Montana from Yellowstone National Park eastward. Does not currently meet criteria of the Montana Natural Heritage Program's "Species of Special Concern" but is included on a "watchlist," indicating that it may meet the criteria in the near future: global rank G5; state rank S3S4. Montana Fish, Wildlife and Parks status: nongame wildlife.

Diet: Insects; primarily ants, also termites, leaf bugs, beetles, butterflies, moths, spiders, flies, leafhoppers, pseudoscorpions, and ticks.

Key Habitat Associations: Limited use of riparian habitats. Associated with sagebrush over most of its range, but can also occur in manzanita brushland, open montane forests, mountain shrublands, and pinyon-juniper forests. Habitat requirements are thought to be open ground, good light, and scattered low bushes (Stebbins 1985). Primarily a ground dweller and seeks shelter in rocks and thick brush. Often found at the base of rocky ledges (Hammerson 1999).

Elevation (throughout range): $150-2,530 \mathrm{~m}$.

Comments: Rangeland "improvements" such as clearing sagebrush followed by replacement by grass communities have resulted in population declines in Idaho (Reynolds 1979). Sagebrush lizard is territorial, and survival of immigrants is lower than residents (Tinkle et al. 1993); this life history characteristic may be important if habitat is destroyed and sagebrush lizards are forced to find new territories. Size of home range is unknown.

\section{Rubber Boa (Charina bottae)}

Occurrence: Specimens have been collected in Livingston and Bozeman latilongs. Neither specimens nor evidence has been reported for Columbus latilong (Thompson 1982, Montana Natural Resources Information System 2000). Occurs in western third of Montana. Museum specimens and other observations exist for Park and Gallatin Counties. Predicted to occur in drainages in Livingston, Bozeman, and Columbus (except center and NE quadrant) latilongs (Redmond et al. 1998). Known to occur along the Yellowstone River near Gardiner (Koch and Peterson 1995).

Abundance and Status: Common. Not a "Species of Special Concern" or "watchlisted" by the Montana Natural Heritage Program: global rank G5; state rank S4. Montana Fish, Wildlife and Parks status: nongame wildlife.

Diet: Lizards, birds, small mammals (especially mice and shrews), and occasionally salamanders and other snakes.

Key Habitat Associations: Riparian associate. Generally found in montane riparian habitats at higher elevations, in sandy areas along rocky streams, and in damp grass meadows (Place 1992). Can also be found in grassland, broken chaparral, woodland, and coniferous forests. Uses spaces under rotting logs, rocks, and bark of fallen trees. It is a good swimmer, burrower, and climber (Stebbins 1985). Associated 
with rocky areas, loose soil, and leaf litter, near shrubs and trees, typically near riparian areas adjacent to streams and in meadows (Koch and Peterson 1995).

Elevation (throughout range): Sea level to $3,050 \mathrm{~m}$.

Comments: Home range is unknown. An unpublished estimate is small, only a few hectares (M. Dorcas, personal communication). Difficult to detect due to being nocturnal, fossorial (burrowing), and slowmoving (Koch and Peterson 1995).

\section{Racer (Coluber constrictor)}

Occurrence: Specimens have been collected in Livingston, Bozeman, and Columbus latilongs (Thompson 1982, Montana Natural Resources Information System 2000). Occurs statewide in open and semi-open habitats (Flath 1984). Observations have been reported from Gallatin County and museum specimens exist from Sweetgrass County; no records from Park County. Predicted to occur in Livingston and Columbus latilongs in areas along Yellowstone River and in much of Bozeman latilong (Redmond et al. 1998). Localized in western Montana valleys. Stebbins (1985) shows the range of two subspecies in all but the NW quarter of the state. Known to occur along the Yellowstone River near Gardiner (Koch and Peterson 1995).

Abundance and Status: Not a "Species of Special Concern" or "watchlisted" by the Montana Natural Heritage Program: global rank G5; state rank S5. Montana Fish, Wildlife and Parks status: nongame wildlife.

Diet: Large insects and small vertebrates, including mice and reptiles (e.g., lizards and frogs).

Key Habitat Associations: Riparian associate. Associated with semi-arid as well as moist habitats. Occurs in semi-open to open habitat in shortgrass prairie, sagebrush flats, riparian woodlands, shrubby foothill canyons, and other forested and agricultural areas. Frequents basking sites used by lizards (lizards are a prey species for the racer) and grassy areas. Primarily a ground dweller and can often be found in streamside grasses. Apparent continuity of home ranges: in Utah, $93 \%$ of 283 racers returned to hibernate in the same burrow used the previous year (Brown and Parker 1976).

Elevation (throughout range): Sea level to $2,550 \mathrm{~m}$.

Comments: Home range size ranges from 0.18 to 9.3 ha (Macartney et al. 1988). In Michigan, maximum distance moved between captures that were at least 2 days apart was $881 \mathrm{~m}$ (Rosen 1991).

\section{Western Terrestrial Garter Snake (Thamnophis elegans)}

Occurrence: Specimens have been collected in Livingston and Bozeman latilongs. Evidence has been reported for Columbus latilongs (Thompson 1982, Montana Natural Resources Information System 2000). Occurs in the western and southern part of Montana. Museum specimens exist for Park, Gallatin, and Sweetgrass Counties. Predicted to occur throughout Livingston, Bozeman, and Columbus latilongs (Redmond et al. 1998). Known to occur along the Yellowstone River near Gardiner (Koch and Peterson 1995). 
Abundance and Status: Common. Not a "Species of Special Concern" or "watchlisted" by the Montana Natural Heritage Program: global rank G5; state rank S5. Montana Fish, Wildlife and Parks status: nongame wildlife. Most abundant and commonly observed reptile in Yellowstone and Grand Teton National Parks (Koch and Peterson 1995).

Diet: Opportunistic, both on land and in water. Eats earthworms, slugs, leeches, various fishes, larval and metamorphosed frogs and toads, small birds, small rodents, and new-born conspecifics (Rossman et al. 1996).

Key Habitat Associations: Riparian associate. Associated with streams, ponds, and borders of mountain lakes. Primarily terrestrial but the wandering subspecies (found in Montana) is also aquatic. Most common at lower elevations around flowing or non-flowing water, but are not restricted to riparian areas. Will inhabit terrestrial habitats far from water (Hammerson 1999). Rarely found in alpine tundra (Hammerson 1999). From late fall through early spring, hibernates continually, typically in rocky areas with southerm exposures near water; sometimes beneath human-made structures. Usually breeds in the spring near the den site and later disperses to foraging sites near water (Koch and Peterson 1995).

Elevation (throughout range): Generally below 3,355 m.

Comments: Home range size in British Columbia was estimated at 10-10,000 $\mathrm{m}^{2}$ (Farr 1988). Most common snake in most of Montana (Reichel and Flath 1995).

\section{Western Rattlesnake (Crotalus viridis)}

Occurrence: Specimens have been collected in Livingston and Bozeman latilongs. Evidence has been reported for Columbus latilongs (Thompson 1982). More recently, no evidence has been reported for Livingston latilong (Montana Natural Resources Information System 2000). Museum specimens exist from Sweetgrass and Gallatin Counties but not Park County. Occurs in most of Montana. Predicted to occur throughout most of Livingston, Bozeman, and Columbus latilongs (Redmond et al. 1998). Known to occur along the Yellowstone River near Gardiner (Koch and Peterson 1995).

Abundance and Status: Locally common. Not a "Species of Special Concern" or "watchlisted" by the Montana Natural Heritage Program: global rank G5; state rank S4. Montana Fish, Wildlife and Parks status: nongame wildlife.

Diet: Mice, ground squirrels, rabbits, other small to medium mammals, nestling birds, lizards, other snakes, and amphibians. Cannibalism is uncommon, but a female rattlesnake found in Montana had eaten a smaller rattlesnake (Genter 1984).

Key Habitat Associations: Limited use of riparian habitats. Associated with a variety of habitats. Often found in open and arid country, but also found in ponderosa pine stands and mixed grass-coniferous forests. Terrestrial, occurring on rocky outcrops, ledges, talus slopes, and rocky stream courses. Apparently avoids high mountains and areas that are perennially wet. Uses crevices, brushy vegetation, small mammal burrows, and woodpiles as retreats. Hibernates in rodent burrows or crevices in rocky outcrops (Stebbins 1985). Movements to maternity rookeries in Wyoming were found to be spatially direct, with the females generally sedentary once in the rookeries (Graves and Duvall 1993). 
Elevation (throughout range): Sea level to $3,350 \mathrm{~m}$.

Comments: Tends to wander during summer $<1$ mile per day (Klauber 1997). The related sidewinder in the Mojave desert averaged $128.3 \mathrm{~m}$ of daily movement and had a home range of $14.7 \mathrm{~m}^{2}$ (Secor 1992). Spring foraging migrations of rattlesnakes in Wyoming averaged 5,640 m (Duvall et al. 1985). Mating occurs in July and August in Wyoming (King and Duvall 1990).

\section{Mammals}

\section{Water Shrew (Sorex palustris)}

Occurrence: Specimens have been collected in Livingston, Bozeman, and Columbus latilongs (Thompson 1982, Montana Natural Resources Information System 2000). Predicted to occur throughout drainages in Livingston and Bozeman latilongs and NW, SW, and SE quadrants of Columbus latilong (Redmond et al. 1998). Year-round resident in central and western Montana (Hall 1981).

Abundance and Status: Common. Not a "Species of Special Concern" or "watchlisted" by the Montana Natural Heritage Program.

Diet: Aquatic insect larvae and adult aquatic invertebrates; also, terrestrial insects, snails, earthworms, and fungi.

Key Habitat Associations: Riparian obligate. Usually found less than $1 \mathrm{~m}$ from water. Water provides food and escape from predators. Associated with water and various structures that provide cover. Found in Montana near streams with banks composed of large boulders and tree roots (Streubel 1989). Associated with northerm forests and Canadian or Hudsonian life-zone montane forests to south. Associated with heavy vegetative cover, logs, rocks, and crevices that afford high humidity (Wilson and Ruff 1999). Most commonly found in habitats with approximately $75 \%$ ground cover. Water needs to be open and moving. Associated with grass-sedge marshes and willow-alder shrub zones along creeks and ponds. Not associated with sedge-moss or heather-moss bogs or with tamarack swamps (Beneski and Stinson 1987).

Elevation (throughout range): $1,829-2,590 \mathrm{~m}$.

Comments: Size of home range is unknown.

\section{Preble's Shrew (Sorex preblei)}

Occurrence: Specimens have not been collected in Livingston or Bozeman latilongs; two have been collected in Columbus latilong (Thompson 1982, Montana Natural Resources Information System 2000). Predicted to occur in NE quadrant of Livingston latilong, SE quadrant of Bozeman latilong, and NW, SW, and SE quadrant of Columbus latilong (Redmond et al. 1998). Up to two records have been reported for the Greater Yellowstone Ecosystem; one report at Hebgen Lake, Gallatin National Forest (Clark et al. 1989). 
Abundance and Status: Rare. A Montana Natural Heritage Program "Species of Special Concem": global rank G4; state rank S3.

Diet: Insects.

Key Habitat Associations: Occasional use of riparian habitats. Associated with arid and semi-arid shrubgrass habitats and openings in coniferous forests dominated by sagebrush (Artemisia tridentata). Rarely reported in wet meadow, marsh, and riparian habitats. In Montana, found in arid shrub-grasslands (Cornely et al. 1992). In Washington, found in fir and pine forests. In Utah, found in wet alkaline habitat. In Colorado, found in habitat of Gambel's oak and sparse grass. In New Mexico, found in open stands of ponderosa pine with understory of Gambel's oak and grass (Wilson and Ruff 1999).

Elevation (throughout range): 900-2,750 m.

Comments: Distributed in widely separated, small localities in the western U.S. The biology and life history of this uncommon shrew, including the size of its home range, are virtually unknown (Wilson and Ruff 1999). Among smallest members of the genus Sorex.

\section{Fringed Myotis (Myotis thysanodes)}

Occurrence: Specimens have not been collected in Livingston or Columbus latilongs. Specimens have been collected in Bozeman latilong (Thompson 1982); however, more recent literature shows them absent from the latilong (Montana Natural Resources Information System 2000). Predicted to occur throughout Bozeman latilong and to be absent from Livingston and Columbus latilongs (Redmond et al. 1998). Occurrence is suspected in Gallatin County but not in Park or Sweetgrass Counties (Flath 1984). Occurs in southwestem Montana (Hall 1981). Specimens exist for Ravalli, Missoula, and Lewis and Clark Counties (Hendricks et al. 1996).

Abundance and Status: Rare (Flath 1984). A Montana Natural Heritage Program "Species of Special Concern": global rank G5; state rank S3.

Diet: Insects, especially small beetles gleaned from the surface of vegetation (Wilson and Ruff 1999).

Key Habitat Associations: Occasional use of riparian habitats. Associated with a variety of habitats, from desert to grassland to woodland (e.g., Thomas and West 1991). In Montana, associated with montane and upland forests but also appears in desert scrub and some non-wooded areas. Frequently observed at dusk foraging along water courses and over standing water (Hendricks et al. 1996). Throughout range, oak and pinyon woodlands appear to be most commonly used vegetative associations (O'Farrell and Studier 1980). Tends to roost in buildings, rock crevices, caves, mines, and under bridges. Often seeks drinking water soon after evening emergence from roosts (Christy and West 1993).

Elevation (throughout range): $1,200-2,400 \mathrm{~m}$

Comments: Generally uncommon at edges of range (Clark et al. 1989). Study site is at northern edge of range. Maternity roosts (occupied solely by females and young) are typically used from late April to late September. Commonly coexists with Townsend's big-eared bat (Wilson and Ruff 1999). Easily disturbed 
by human presence (O'Farrell and Studier 1980). Easily capturèd at cave entrances and roost sites (Clark et al. 1989).

\section{Townsend's Big-eared Bat (Corynorhinus townsendii)}

Occurrence: Specimens have not been collected in Livingston or Columbus latilongs. Specimens have been collected in Bozeman latilong (Thompson 1982, Montana Natural Resources Information System 2000). Predicted to occur throughout Livingston, Bozeman, and Columbus latilongs (Redmond et al. 1998). Occurrence is suspected in Park, Gallatin, and Sweetgrass Counties (Flath 1984). They have been detected in all districts of the Kootenai National Forest (Hendricks et al. 1996) and have been found at locations in western and south-central to eastern Montana (Pierson et al. 1999).

Abundance and Status: Uncommon to rare over most of its wide range (Clark et al. 1989). A Montana Natural Heritage Program "Species of Special Concern": global rank G4; state rank S2S3. USFS: sensitive. BLM: special status. Montana Fish, Wildlife and Parks status: unprotected nongame species. Considered common in highland areas of western North America (Kunz and Martin 1982). More commonly observed in winter than in summer (Wilson and Ruff 1999).

Diet: Lepidopteran specialists; diet consists of $>90 \%$ moths (Pierson et al. 1999 and references therein).

Key Habitat Associations: Riparian associate. Associated with moist forests, arid savannah, and shrubsteppe. In Greater Yellowstone Ecosystem, forages over sagebrush-grassland, riparian areas, open pine forests, and arid scrub. Roosts in rocky outcrops, caves, and old mines (Clark et al. 1989). Common in mesic habitats characterized by coniferous and deciduous forests (Kunz and Martin 1982); coniferous forests may also be wet (Hendricks et al. 1996). Forages in edge habitats between forests and openings. Typically feeds over open pastures. Roosts in buildings, caves, mines, and sometimes under bridges. Often seeks drinking water soon after evening emergence from roosts. Emerges from 30 minutes to 1 hour after sunset (Christy and West 1993). Relatively sedentary, undergoing no long-distance migrations (Humphrey and Kunz 1976).

Elevation (throughout range): Distribution is correlated with the availability of caves and cave-like roosting habitat, from sea level on the Pacific Coast to $2,900 \mathrm{~m}$ in Colorado and up to $3,188 \mathrm{~m}$ in the White Mountains of California.

Comments: Precipitous declines reported in Idaho, Oregon, and Washington (Clark et al. 1989). Highly susceptible to disturbance; often roosts in exposed locations (Bogan and Cryan 2000); vulnerable to disturbance or habitat loss (Flath 1984). Maternity roosts are typically used from mid-March to midSeptember (Wilson and Ruff 1999). Mating occurs in fall and winter (Hendricks et al. 1996). Reported range of foraging activity for females is $1.0-4.2 \mathrm{~km}$, with the greater distance occurring during peak lactation (Christy and West 1993).

\section{Gray Wolf (Canis lupus)}

Occurrence: Specimens have not been collected in Livingston latilong. Evidence has been reported for Bozeman and Columbus latilongs (Thompson 1982, Montana Natural Resources Information System 2000). Occurs 
in western Montana in relict populations in more remote areas (Flath 1975). Predicted to occur in S half of Livingston, Bozeman, and Columbus latilongs (Redmond et al. 1998).

Abundance and Status: Rare in Montana. A Montana Natural Heritage Program "Species of Special Concern": global rank G4; state rank S1. USFS status: endangered in the lower 48 states. Montana Fish, Wildlife and Parks status: endangered. Considered extinct in most of Montana (Thompson 1982).

Diet: Ungulates, beavers, hares, other small mammals, and domestic stock. Old, sick, or injured animals constitute the majority of prey items. Detailed information on prey species and percentages of prey species taken by wolves is available (Mech 1974, 1981).

Key Habitat Associations: Occasional use of riparian habitats. Occupies all habitats of the Northem Hemisphere except arid deserts and tropical forests (Mech 1974, Nowak 1991). Associated with an ungulate prey base that includes deer, elk, moose, and bison (Clark et al. 1989).

Elevation (throughout range): Widespread.

Comments: Ranges widely. Study site is south of southernmost range. Territory sizes range from 130 to $13,000 \mathrm{~km}^{2}$. Gray wolves were formerly widely distributed throughout the Northern Hemisphere north of $20^{\circ}$ latitude and are now restricted to Canada, Alaska, northern Minnesota, Wisconsin, Michigan, and Montana (Wilson and Ruff 1999). Wolf packs were eliminated from Montana by 1936; they colonized Glacier National Park in 1979; first wolf den there was documented in 1986. Fourteen wolves were reintroduced into Yellowstone National Park beginning in 1995 (Aderhold 1996). Generally found in packs of 5-10 (Wilson and Ruff 1999).

\section{Lynx (Lynx lynx)}

Occurrence: Specimens have been collected in Livingston and Bozeman latilongs. Neither specimens nor other evidence has been reported for Columbus latilong (Thompson 1982). Occurs in Park and Gallatin Counties (Flath 1984). Predicted to occur throughout most of Livingston latilong, $S$ half of Bozeman latilong, and SW quadrant of Columbus latilong (Redmond et al. 1998).

Abundance and Status: Uncommon. Undetermined in Park and Gallatin Counties (Flath 1984). A Montana Natural Heritage Program "Species of Special Concern": global rank G5; state rank S2. USFS status is sensitive. Montana Fish, Wildlife and Parks status: fur bearing animal, restricted harvest. Scarce in the Greater Yellowstone Ecosystem (Clark et al. 1989).

Diet: Primarily snowshoe hares (as much as $83 \%$ of diet); secondarily, squirrels, beavers, muskrats, other small mammals, deer, moose, and birds (Galliformes and Anseriformes) (Tumlison 1987).

Key Habitat Associations: Occasional use of riparian habitats. Associated with rocky outcrops and bogs/ thickets characterized by deep snow and low temperatures in winter; also boreal forests with openings (Banfield 1974, Tumlison 1987, Wilson and Ruff 1999). In western Montana, occurs in dense subalpine forest in the Rocky Mountains and makes excursions into surrounding valleys during winter (Brainerd 1989). Predicted associations for Greater Yellowstone Ecosystem are dense lodgepole pine forests for hunting and higher-elevation spruce-fir forests for denning. Willow flats and aspen forests with dense 
shrub understories would be used (Clark et al. 1989). Dens may be in rock piles, broken rocky ledges, brush piles, hollow trees and logs (Chapman and Feldhamer 1982).

Elevation (throughout range): Varies; generally found in higher-elevation boreal forests.

Comments: Crepuscular. Solitary, with the exception of females with young. Large home ranges, varying from 11 to $300 \mathrm{~km}^{2}$ (Wilson and Ruff 1999). Dispersal distances during periods of irruption range up to $483 \mathrm{~km}$ (Tumlison 1987). Historically, not common.

\section{Wolverine (Gulo gulo)}

Occurrence: Evidence has been reported for Livingston latilong. Specimens have been collected in Bozeman latilong. Neither specimens nor other evidence has been reported for Columbus latilong (Thompson 1982, Montana Natural Resources Information System 2000). Predicted to occur throughout most of Livingston, Bozeman, and Columbus latilongs (Redmond et al. 1998). Occurs in Park and Gallatin Counties and is suspected in Sweetgrass County (Flath 1984).

Abundance and Status: Common in Park and Gallatin Counties (Flath 1984). A Montana Natural Heritage Program "Species of Special Concern": global rank G5T4; state rank S2. Montana Fish, Wildlife and Parks status: fur bearing animal, restricted harvest. Occurs in low population densities throughout its range. In Montana, a study area of $1,300 \mathrm{~km}^{2}$ contained 20 individuals (Nowak 1991). Rare in the Greater Yellowstone Ecosystem (Clark et al. 1989).

Diet: Primarily carrion (moose, caribou); secondarily, lemmings, ground squirrels, snowshoe hares, ptarmigan, and less commonly, eggs of ground nesting birds, fish, and berries. Larger mammals (e.g., wild sheep) in winter when snow slows down the prey species (Nowak 1991).

Key Habitat Associations: Occasional use of riparian habitats. Associated with forests, mountains, and open plains. In Montana, occurs in forests of alpine fir, Douglas fir, and lodgepole pine (Pasitschniak-Arts and Lariviere 1995). Large parks, meadows, and clear cuts are generally avoided. Hunts in riparian areas, small meadows, timbered thickets, streambeds, tree wells, and rocky sites. Dens in snow caves, tunnels, uprooted trees, and rock crevices (Clark et al. 1989).

Elevation (throughout range): Great variation, remote mountainous areas to coastal tundra in Alaska and the far north.

Comments: Study site is on eastern edge of range. Largely nocturnal. Generally solitary. Home ranges can range from 100 to $>600 \mathrm{~km}^{2}$ (Wilson and Ruff 1999). Habitat loss and predation by humans are the main factors reducing wolverine numbers (Pasitschniak-Arts and Lariviere 1995).

\section{Grizzly Bear (Ursus arctos)}

Occurrence: Evidence has been reported for Livingston, Bozeman, and Columbus latilongs (Thompson 1982, Montana Natural Resources Information System 2000). Predicted to occur in S half of Livingston, Bozeman, and Columbus latilongs (Redmond et al. 1998). Occurs in Park and Gallatin Counties and is suspected in Sweetgrass County (Flath 1984). Extinct in eastern Montana (Thompson 1982). 
Abundance and Status: Throughout Montana, exists less than half the former population level. Common in Park and Gallatin Counties. Rare in Sweetgrass County (Flath 1984). A Montana Natural Heritage Program "Species of Special Concern": global rank G4T3; state rank S1S2. USFWS status: threatened. USFS status: threatened. Montana Fish, Wildlife and Parks status: game animal, restricted harvest.

Diet: Omnivorous. Diet includes grasses, tubers, mosses, willows, berries, insects, larvae, grubs, fungi, bird eggs, acorns, nuts, small mammals, carrion, and ungulates (Pasitschniak-Arts 1993).

Key Habitat Associations: Riparian associate. Associated with remote wilderness areas, especially avalanche chutes where berry production is high (Pasitschniak-Arts 1993, Waller and Mace 1997). Heavily concentrated in habitats where a mosaic of community types occurs, ranging through mixed spruce-fir and deciduous forest, open meadows, avalanche chutes, wet meadows, and riparian areas (Clark et al. 1989). Occurs in open plains and mountainous forests (Wilson and Ruff 1999). Low elevation riparian zones are used in spring, when bears will traverse agricultural lands (Servheen 1983). Dens are generally in welldrained sites, often on north-facing slopes (Wilson and Ruff 1999).

Elevation (throughout range): Will adapt to a wide range of climate and habitat, including elevation.

Comments: Breeds between mid-May and July. Normally active at night and twilight hours (Wilson and Ruff 1999). Home ranges of 55-234 $\mathrm{km}^{2}$ are common; range varies with the age and sex of the bear (Clark and Stromberg 1987). Loss of habitat is a major threat.

\section{Uinta Chipmunk (Tamias umbrinus)}

Occurrence: Specimens have been collected near the Livingston latilong and in the Columbus latilong. Neither specimens nor other evidence has been reported for Bozeman latilong (Thompson 1982, Montana Natural Resources Information System 2000). Predicted to occur in S half of Livingston, Bozeman, and Columbus latilongs (Redmond et al. 1998). Occurs in Park County and is suspected in Sweetgrass County; absent in Gallatin County (Flath 1984).

Abundance and Status: Total range within Montana is restricted to less than 6 counties (Flath 1984). A Montana Natural Heritage Program "Species of Special Concern": global rank G5; state rank S3.

Diet: Specializes on coniferous seeds and a variety of shrubs. In addition, fruits and seeds of other plants, some herbaceous foliage and flowers, buds from woody plants, mushrooms, insects (especially soft larvae), bulbs, and occasionally bird eggs.

Key Habitat Associations: Occasional use of riparian habitats. Associated primarily with ponderosa pine forests and woodlands of the montane life zone; forests include Douglas fir, spruce, and juniper. May also occupy pinyon pine-juniper woodlands and other dry, open habitats, such as sagebrush plains and brushcovered mountains. Spends most time in trees, but generally uses burrows on ground for sleeping and winter torpor. Associated with a small-rodent community, including least chipmunk or other chipmunk species, golden-mantled ground squirrel, Abert's squirrel, red squirrel, bushy-tailed woodrat, deer mouse, red-backed vole, long-tailed and other voles (Wilson and Ruff 1999).

Elevation (throughout range): $2,135-3,447 \mathrm{~m}$. 


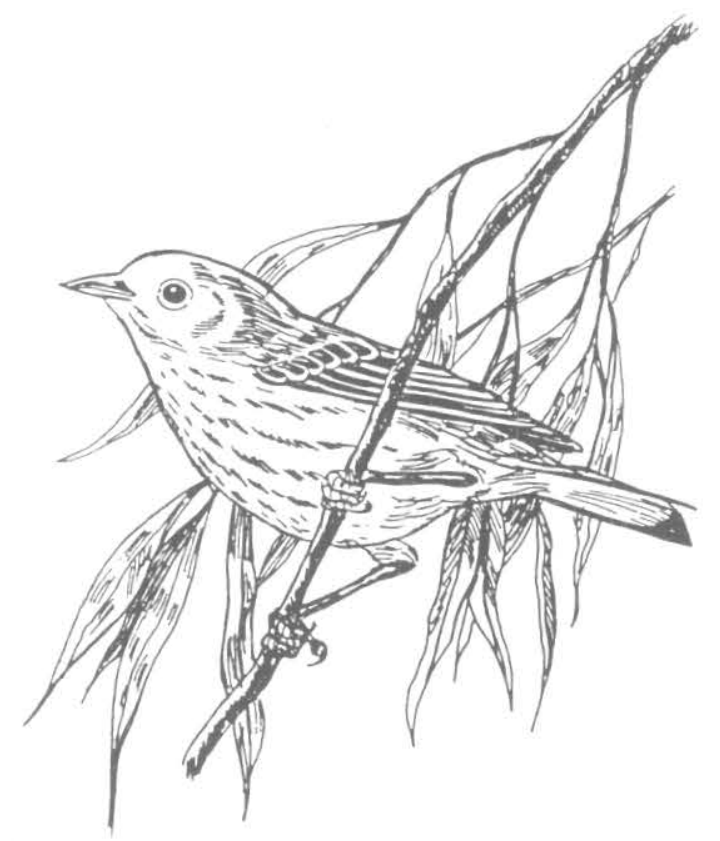

Yellow Warbler

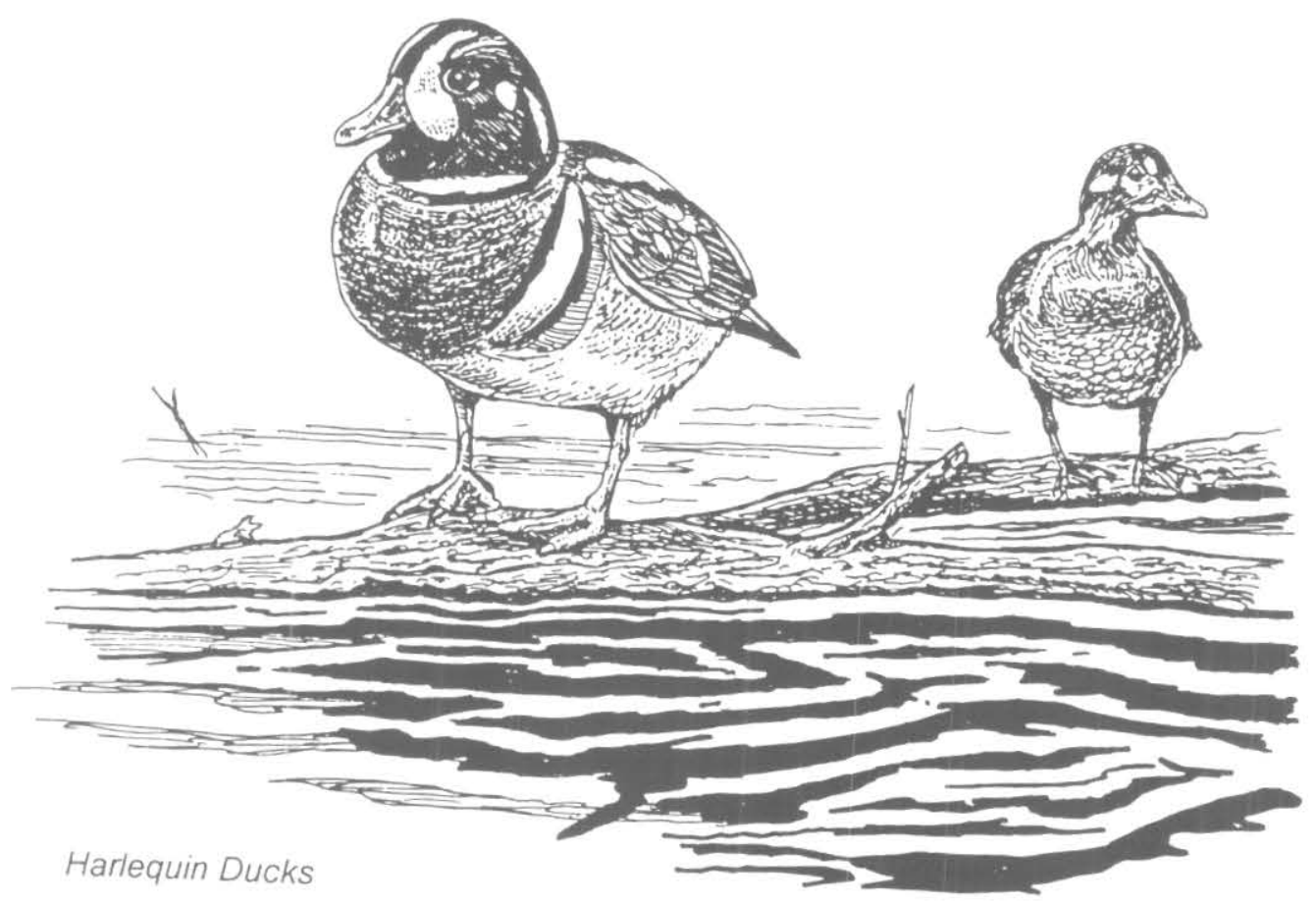




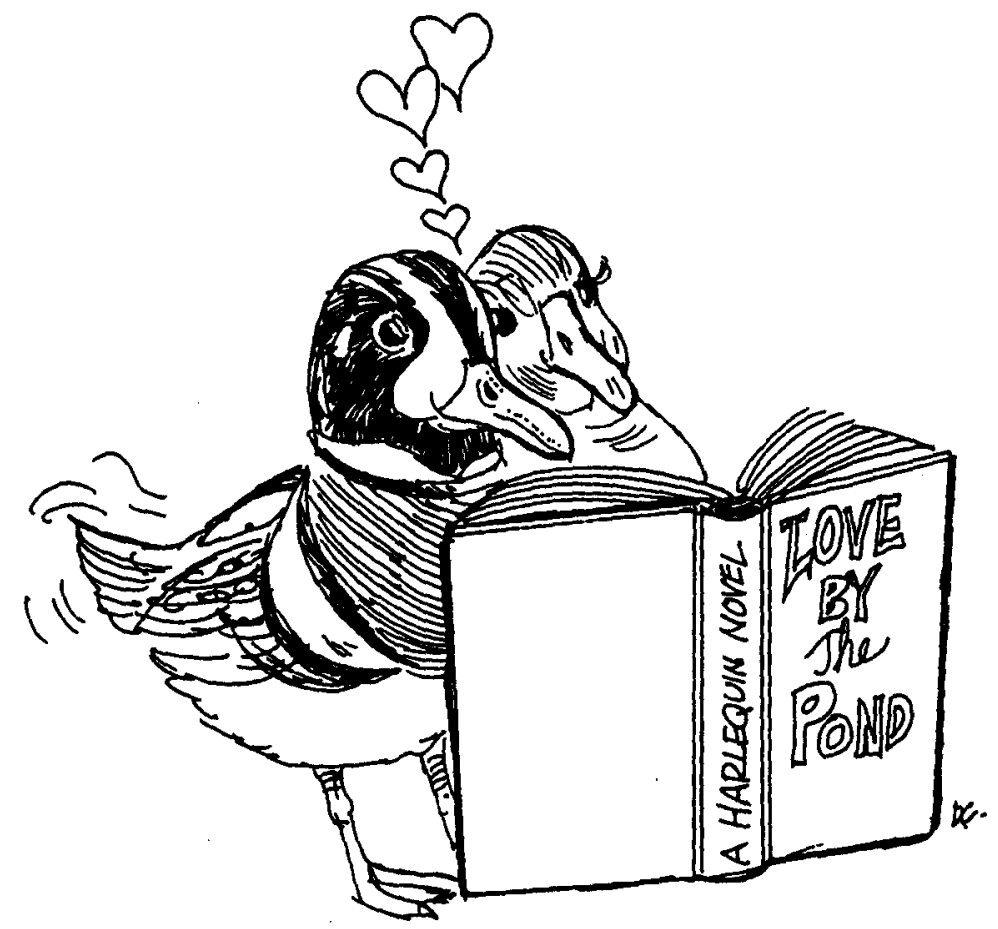

Harlequin Ducks 